\author{
Universidade de São Paulo \\ Faculdade de Filosofia, Letras e Ciências Humanas \\ Departamento de Geografia \\ Programa de Pós Graduação em Geografia Física
}

\title{
Para onde cresce a cidade: Dinâmica de expansão urbana e caracterização urbano-ambiental em área da bacia do Guarapiranga
}

Mariana Bielavsky

São Paulo

2006 
Universidade de São Paulo

Faculdade de Filosofia, Letras e Ciências Humanas

Departamento de Geografia

Programa de Pós Graduação em Geografia Física

\section{Para onde cresce a cidade: Dinâmica de expansão urbana e caracterização urbano-ambiental em área da bacia do Guarapiranga}

Mariana Bielavsky

Dissertação apresentada ao programa de Pós-Graduação em Geografia Física, do Departamento de Geografia da Faculdade de Filosofia, Letras e Ciências Humanas da Universidade de São Paulo, para obtenção de titulo de Mestre em Geografia

Orientador: Professor Doutor Ailton Luchiari

São Paulo

2006 


\section{DEDICATÓRIA}

Dedido esse trabalho a Deus e a todas as forças da natureza 


\section{Agradecimentos}

A Deus

Meu orientador desde a iniciação cientifica - Ailton Luchiari

Minha irmã, a biomédica mais especializada em Guarapiranga - Monica Bielavsky

Multispectral e Cognatis, por todo o apoio e informações cedidas

Meus amigos e minha família, todos contribuíram para essa pesquisa 


\section{RESUMO}

Essa pesquisa trata do crescimento urbano e implicações ambientais de uma área na bacia do Guarapiranga. Essa área abrange parte dos municípios de São Paulo, Itapecerica da Serra e Embu Guaçu.

O intuito é apresentar a evolução urbana da área entre os anos 1962 e 2001, com analises de fotografias áreas.

Em uma escala intra-urbana, a pesquisa apresenta a interpretação de fotografias áreas para o ano de 2001 criando a carta de áreas homogêneas urbanas.

Os principais dados dessa pesquisa são para o ano de 2001, de modo que pudemos os indicadores sócio-demográficos dos dados do censo do IBGE realizado para o ano de 2000.

Com todos esses dados, podemos apontar os vetores de crescimento urbano da área, assim como seus problemas sócio-ambientais.

\section{ABSTRACT}

This research is about the urban growing in an area wich is considered model in the Guarapiranga's Basin. This area encloses the citys of São Paulo, Itapecerica da Serra and Embu Guaçu.

The intention is present the urban evolution of the area between the years 1962 and 2001, with analyses of aerial photography.

In intra urban scale, the research presents the aerial photography's urban interpretation for the year 2001, making the maps of the urban homogenous zones areas.

The main data or this research is about the year 2001, in the way that we could have the social demography in the IBGE's censo data for the year 2000.

With all this data, we have got the growing expansion city vectors as also the social and ambient problems. 


\section{Palavras chaves/Key Words}

\section{Palavras chaves}

Ambiente urbano

Fotografias aéreas

Geoprocessamento

Demografia

Crescimento urbano

\section{$\underline{\text { Key Words }}$}

Urban enviroment

Aerial image

Geoprocessing

Demography

Urban growing 


\section{Índice da dissertação}

DEDICATÓRIA

$\begin{array}{ll}\text { Agradecimentos } & 4\end{array}$

RESUMO

ABSTRACT

Palavras chaves/Key Words $\quad 6$

Palavras chaves 6

Key Words

$\begin{array}{ll}\text { Índice da dissertação } & 7\end{array}$

$\begin{array}{lr}\text { Índice de tabelas } & 8\end{array}$

$\begin{array}{lr}\text { Índice de Gráficos } & 8\end{array}$

$\begin{array}{lr}\text { Índice de figuras } & 8\end{array}$

1. Apresentação 10

1. Apresentação 10

2. Objetivos

3. O urbano, a expansão, e os problemas ambientais 12

3.1 Urbanização e caracterização da cidade 12

3.1.1 Urbanização da cidade de São Paulo 12

3.1.2 São Paulo - metrópole urbana global__ 16

3.1.3 Questão Ambiental _ 19

3.1.4 Leis de recursos hídricos _ 20

3.2 Unidades Homogêneas da paisagem $\quad 22$

3.2.1 Unidades homogêneas urbanas __ 23

3.3 Mapeamento Urbano e ambiental - Geotecnologias ___ 25

3.3.1 Imagens de sensoriamento remoto

3.3.2 Sistema de Informações Geográficas__ 26

3.3.5 Fotografias aéreas _ 30

3.3.6 Censo Demográfico__ 31

4. A área de estudo - dinâmica e expansão urbana 34

4.1 Aspectos do ambiente natural 34

4.2 Resultados - Dinâmica de crescimento (60 a 94) 38

4.2.1 Uso da terra em 1962

4.2.2 Uso da terra em $1974 \longrightarrow 43$

4.2.3 Uso da terra $1994 \_46$

5. Áreas homogêneas urbanas (2001) 49

5.1 Chave de interpretação das áreas homogêneas urbanas

5.1.1 Residencial de alto Padrão ___ 53 
5.1.3 Residencial de baixo padrão

5.1.4 Residencial favelas _ 58

5.1.5 Uso não residencial _ 60

5.1.6 Mata nativa

5.1.7 Reflorestamento

5.1.8 Cultivo

5.1.9 Mineração _ 65

5.2 Interpretação da foto e criação da carta de áreas homogêneas urbanas $\quad 70$

5.3 Interpolação dos dados da carta com os dados do censo

5.4 Carta de áreas homogêneas urbanas

5.4.1 Estabelecimentos comerciais e de serviços ___ 76

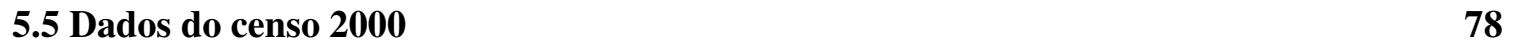

5.6 Associação dados do censo

5.6.1 Domicílios 79

5.6.2 Esgoto e água _ 84

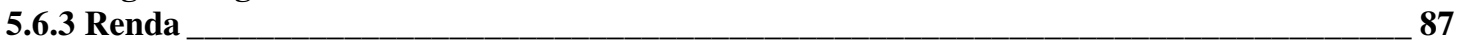

6. Considerações Finais $\quad 96$

7. Referências Bibliográficas 100

\section{Índice de tabelas}

Tabela 1 - Estabelecimentos comerciais e de serviços ..................................... 70

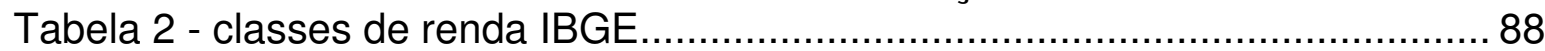

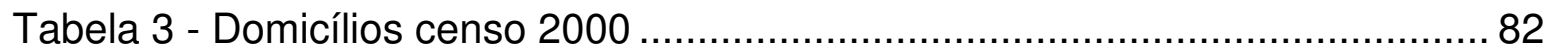

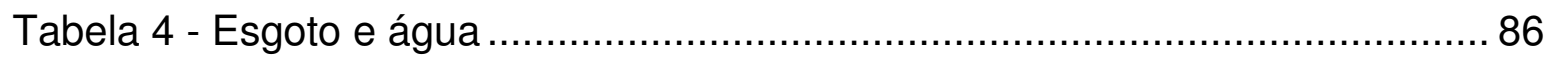

Tabela 5 - Renda

\section{Índice de Gráficos}

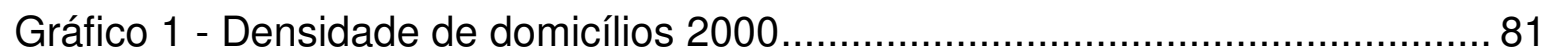

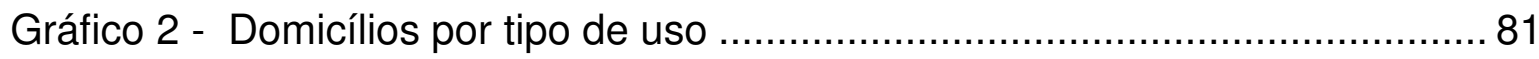

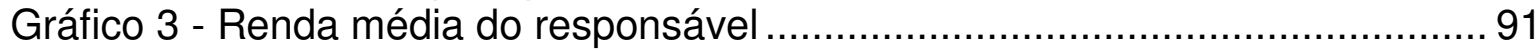

\section{Índice de figuras}

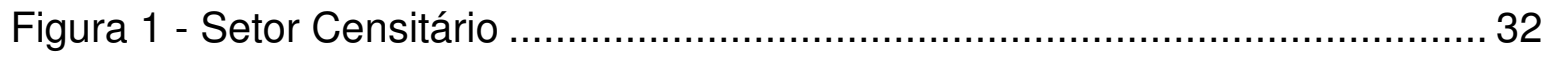

Figura 2 Localização da área de estudo em São Paulo .................................... 37

Figura 3 - Localização da área de estudo - viário de São Paulo ........................... 38

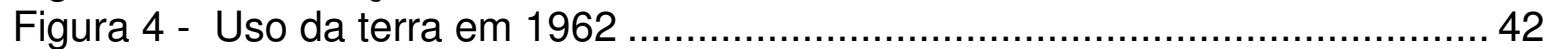

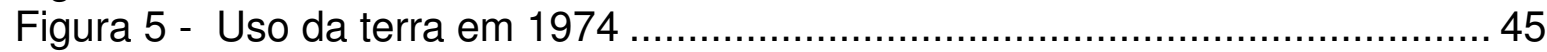

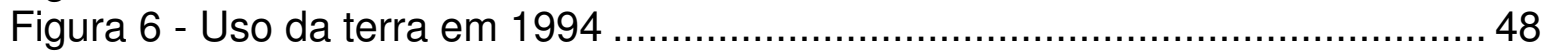

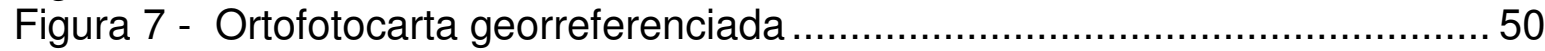

Figura 8 - Localização de parte da orotofotocarta ...........................................51

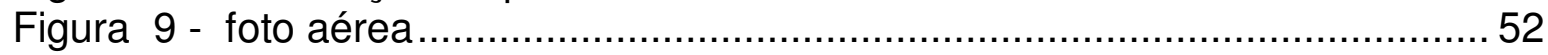

Figura 10 - Residencial de Alto padrão …..................................................... 54

Figura 11 - Alto padrão em baixa densidade ................................................. 55 
Figura 12 - Médio padrão em baixa densidade .............................................. 56

Figura 13 - Médio padrão e baixo padrão ………......................................... 57

Figura 14 - Baixo padrão residencial em baixa densidade ...............................58

Figura 15 - Uso residencial favela - alta densidade .....................................59

Figura 16 - Uso residencial favela - baixa densidade ......................................6 60

Figura 17 - Uso não residencial de grande porte, próximo a Avenida Teotônio Vilela

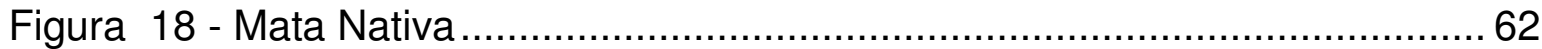

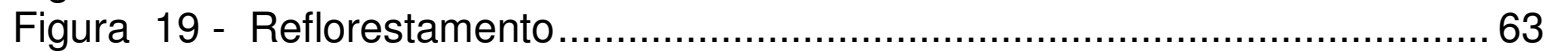

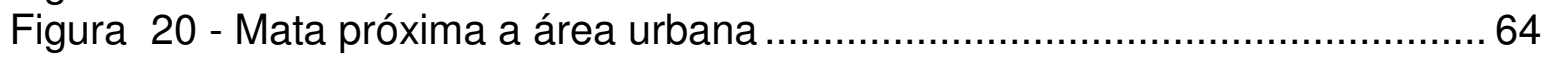

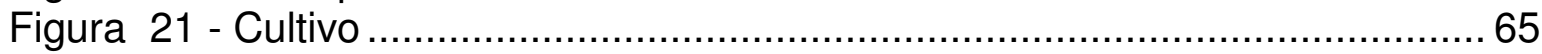

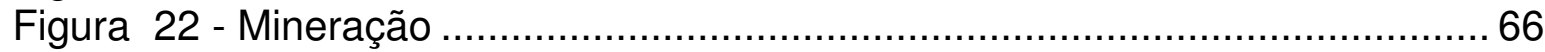

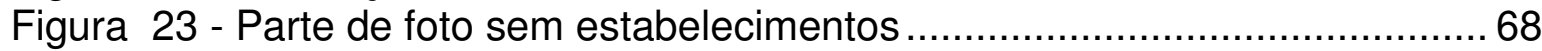

Figura 24 - parte de foto com estabelecimentos ...........................................69

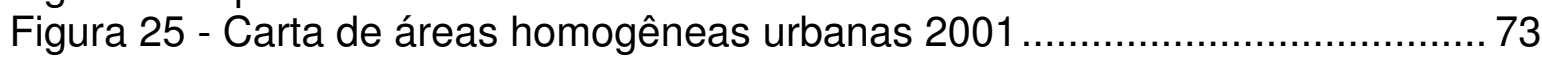

Figura 26 - Estabelecimentos comerciais e de serviços .................................. 77

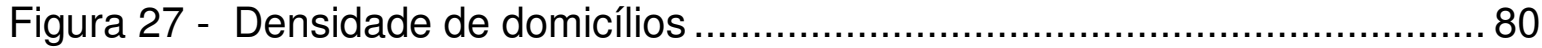

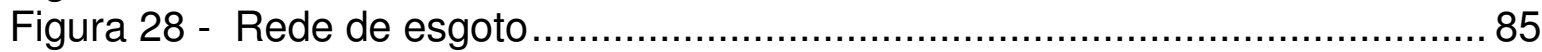

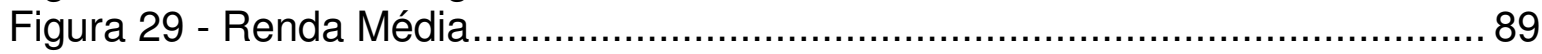




\section{Apresentação}

Essa pesquisa é o resultado de mais de 5 anos de estudo sobre uma área da Bacia do Guarapiranga, começou em 2000 como iniciação cientifica, onde realizamos cartas de uso da terra com base em fotografias aéreas para o não de 1962 e imagem de satélite para 2000 e sua fragilidade ambiental segundo a metodologia do Prof. Dr. Jurandyr Ross (1994); e a continuidade desse trabalho hoje se apresenta como dissertação de mestrado.

Inicialmente a pesquisa de mestrado tratava-se de uma continuação do trabalho de graduação individual, realizado pela aluna no curso de Geografia da FFLCH USP, e tinha como titulo 'Panorama sócio-ambiental na área do reservatório Guarapiranga'

O intuito era continuar o estudo da fragilidade potencial e ambiental da área, seguindo a metodologia do Prof. Dr. Jurandyr Ross. Analisando não só o uso da terra e fragilidade para os anos de 1962 e para 2000, como para anos intermediários 1974 e 1994.

No decorrer da pesquisa, o enfoque mudou. No final do ano de 2004 foram cedidas pela empresa de mapas digitais Multispectral as fotografias aéreas para a área em estudo (somente cidade de São Paulo), para o ano de 2001, assim como os eixos digitais das cidades que englobam a área de estudo.

Com essas fotografias em mãos, vimos a possibilidade de realizar um estudo intra urbano para a área, já que a carta de uso da terra para o ano de 2000 foi realizada a partir de imagem de satélite LandSat TM 5, que não permite um nível de interpretação em escala maior.

Assim foi possível fazer uma analise da dinâmica do crescimento da área em estudo, com a gama de fotografias aéreas para 1962 e 1974 do AFA (Arquivo de Fotografias Aéreas) 1994 (SEHAB/SP), sendo assim dos últimos 30 anos.

As fotografias digitais da Multispectral possuem uma resolução espacial maior que as fotografias obtidas no AFA, podendo assim ampliá-las em um ambiente SIG e trabalharmos em nível intra-urbana. Diferentemente das cartas de uso da terra que 
já vinham sendo feitas, que apresentam somente a mancha urbana e não o aspecto intra-urbano. Assim, esse trabalho preocupa-se em melhorar tais mapeamentos.

Para complementar esse estudo, utilizamos os dados do censo de 2000, ano compatível com as fotografias aéreas da empresa de mapas digitais Multispectral, apresentando dados de renda, população e densidade de domicílios entendendo para onde a cidade cresce, e como ela invade essa importante área de manancial da Região Metropolitana da Cidade de São Paulo.

\section{Objetivos}

A pesquisa tem como objetivo apresentar a expansão urbana na área limítrofe da cidade São Paulo, e acaba abrangendo parte das cidades de Embu-Guaçu e Itapecerica da Serra que fazem parte da região da Bacia do Guarapiranga.

A expansão urbana é apresentada em duas formas e em dois momentos: Primeiro, para os anos de 1962, 1974 e 1994, representando a dinâmica do crescimento urbano das áreas. E para o ano de 2001 detalhamos as características intra-urbana da área em estudo; mostrando o tipo de urbanização da área, seus estabelecimentos comerciais, e a sócio-demografia da população.

A dinâmica do crescimento urbano para os quatro anos é resultado da interpretação de fotografias aéreas. Porém para os três primeiros anos temos fotografias aéreas de resolução espacial mais baixa, não permitindo uma interpretação intra-urbana, podendo apenas ser observado os tipos de mancha urbana da área.

Já para o ano de 2001, como temos uma foto de melhor resolução espacial, foi possibilitada a analise intra-urbana, apresentando as áreas homogêneas urbanas; que são tipos diversos de ocupação que ocorrem na área em estudo. Junto com os dados do censo do IBGE de 2000, avaliarmos não somente da estrutura da expansão urbana, realizar inferências a respeito das características sócio econômicas da população das áreas homogêneas. 


\section{O urbano, a expansão, e os problemas ambientais}

\subsection{Urbanizacão e caracterização da cidade}

O espaço é "acúmulo desigual dos tempos", e temos a cidade como última expressão desse acumulo - um núcleo densamente ocupado numa área continua. (SANTOS, 1978)

Embora a revolução industrial tenha significado a substituição da ferramenta pela máquina, ela fez com que a base econômica deixasse de ser rural e passasse a ser urbana. Esse foi um grande marco da historia mundial, sendo decisiva na transição do capitalismo comercial para o industrial.

Assim a complexidade das funções urbanas se acentuam e a cidade deixa de ser apenas um centro da gestão dos excedentes agrícolas, e passa a ser centro e instrumento de produção. "E como tal deve estruturar-se do modo mais eficiente possível. Isso implica em dispor convenientemente no espaço as adaptações destinadas à produção, ao consumo, a troca e a gestão" (SERRA, 1987).

Assim, o processo de urbanização "exigiu a transferência de grupos sociais das áreas rurais para os aglomerados urbanos, que produziu novas formas de organização de vida em sociedade, a partir de uma nova forma de divisão do trabalho" (LEMOS, 1999).

\subsubsection{Urbanização da cidade de São Paulo}

Até o século XVIII São Paulo mal se destacava no Brasil como uma cidade; fato que começou a ser alterado com a cafeicultura que chegava em 1870 ao oeste paulista.

A mesma década de 1870 marcou o início do crescimento explosivo de São Paulo. Até então, a população era muito menor que a do Rio: em 1872, a primeira tinha 19377 habitantes e a segunda 79 381. Já em 1890, segundo o censo, São Paulo já totalizava uma população de 60564 habitantes, revelando que, entre $1870 \mathrm{e}$ 1900, o crescimento da cidade foi muito grande. (VILLAÇA, 1998). 
Embora tenha sido fundamental para o desenvolvimento de São Paulo, o café durante muito tempo conservou os traços básicos dos antigos engenhos: a produção para exportação, a auto-suficiência quase total quanto às necessidades de subsistência e a concentração do poder nas mãos dos fazendeiros. As cidades continuavam a ter um papel secundário na economia nacional. (VILLAÇA, 1998).

Porém foi esse mesmo café que permitiu que a cidade começasse a apresentar traços de urbanização, principalmente pela existência de vias de acesso pra escoamento da produção. "O fato de o trafego interior-santos convergir em São Paulo e passar diretamente pela cidade conferia obviamente vantagem de cunho econômico a essa. Essa estrada era a passagem de muitos viajantes, o que auxiliou no começo de novas vilas próximas à cidade, já que havia a necessidade de conferir descanso e alimento para os animais e pessoas; muitas fazendas e ranchos encontraram nisso sua subsistência. As estradas na época funcionavam como agentes de povoamento e ocupação do espaço de várias maneiras, mas uma das mais notáveis e a ela mais diretamente relacionada é de provocar o surgimento dos citados estabelecimentos e atividades junto a sua margem ou em seus domínios. A relação funcional existente entre as várias atividades mencionadas provocava não raro, a associação geográfica e financeira das mesmas". (LANGENBUCH,1971).

Era o início da urbanização de São Paulo, processo engendrado pelo café também nesse aspecto dos transportes. Para que a produção cafeeira pudesse ser transportada de maneira mais segura e rápida, começaram a surgir as primeiras estradas de ferro, que além de escoarem o café para o porto de Santos, também foram fundamentais para a interligação dos arquipélagos econômicos regionais "que evoluíam segundo lógicas próprias, ditadas em grande parte por suas relações com o mundo exterior. O Estado de São Paulo passava a ser o pólo dinâmico de uma vasta área". (SANTOS, 1993).

O escoamento, a articulação entre a produção cafeeira, a imigração e o trabalho livre constituiriam as engrenagens para que o quadro de traços básicos dos antigos engenhos fosse mudado. Em virtude da grande procura pelo café e das 
inovações tecnológicas, em pouco tempo, as fazendas do oeste paulista tornaramse empresas tipicamente capitalistas, com trabalho assalariado e um certo grau de mecanização.

Os imigrantes passaram a constituir um incipiente mercado interno, fato que estimulou a produção. Por vezes esse mesmo contingente de estrangeiros, cansado dos maus tratos e da falta de perspectivas no campo, deixavam as fazendas e dirigiam-se para as cidades, onde obtinham trabalho como artesãos, pequenos comerciantes, e futuramente operários. Além dos colonos europeus, os agregados das fazendas de café também constituíram esse embrião da classe média. (VILLAÇA, 1998).

A produção do café e seu escoamento já em 1897 criam a instalação das linhas de trens e das estradas internas á cidade. As prestações de serviço que vinham aparecendo ao longo das estradas acabaram por dar origem aos aglomerados, muitos tinham uma boa ligação com a capital, como a vila da Penha (atual bairro da Penha). "Porém não se verificam relações de migração pendular de mão de obra que pudesse de assemelhar as relações suburbanas típicas de áreas metropolitanas. Isso nem sequer se poderia esperar de uma cidade com menos de 20000 habitantes". ( LANGENBUCH, 1971).

Para atravessar mais rapidamente os bairros, em 1900 temos o bonde elétrico se expandiu, sendo que a concessionária light and power estendeu suas linhas atravessando-os em direção as zonas mais afastadas. Essas expansões dos meios de transporte acabaram por anexar no período de 1875 a 1915 várias chácaras, "Desdobrando o espaço urbano, bairros e loteamentos territorialmente isolados da cidade propriamente dita passam a fazer parte dela, mesmo com uma ocupação urbana efetiva pouco densa". (LANGENBUCH, 1971). Quadro que muda com o fim do café e o começo da industrialização de São Paulo.

No final do século XIX, a economia cafeeira começou a dar os primeiros sinais de crise. A sedução do enriquecimento através da cafeicultura acabou por levar a uma grande expansão do plantio, que por sua vez resultou numa superprodução e numa conseqüente queda de preços. 
Como o café era a base da economia brasileira, os grandes fazendeiros trataram de encontrar meios de evitar ou, pelo menos amenizar os prejuízos na lavoura. Os investimentos em outros setores, como comércio e a indústria de bens de consumo intensificaram-se. Até então, os excedentes gerados pela produção do café eram empregados pela burguesia cafeeira como forma de diversificar suas atividades, e não como uma saída financeira.

A cidade de São Paulo, em especial, firmou-se economicamente tornando-se em pouco tempo pólo industrial. O que no fim do século XIX ainda era uma cidade pequena, rodeada de chácaras que a abasteciam, aos poucos ganhava os ares de cidade grande.

Segundo LEMOS (1999) "a estrutura urbana metropolitana - começa a apresentar cada vez mais espaços para a produção, especialmente industrial; os espaços do consumo, os espaços da distribuição para fazer a relação entre a produção e o consumo, e os chamados espaços residenciais e que agora se denominava reprodução da força de trabalho. Este último, segregado e diferenciado segundo o poder aquisitivo de seus consumidores".

Os bairros que até então eram isolados passaram a ter seus espaços intra urbanos cada vez menores, dada a quantidade de loteamentos, seguindo 0 processo de urbanização da, até então, considerada periferia. Essa metropolização da periferia se mostra em nítidos domínios industriais e residenciais, já que as indústrias atraem cada vez mais operários. (LANGENBUCH, 1971).

Assim temos os primeiros sinais do processo de segregação, que segundo MARCUSE (2001) é o processo por meio do qual uma determinada população é forçada a se agrupar em uma dada área. Esse ocorre com o começo das indústrias e chegando até os dias de hoje, conforme apresenta CASTELLS (1983 in CORREA 1989): "A segregação residencial é, em realidade, um processo que origina a tendência a uma organização espacial em áreas de forte homogeneidade social interna e de forte disparidade entre elas" É um produto da existência de classes sociais, sendo sua espacialização dada no urbano". 
Esse fenômeno de expulsão das classes mais pobres para as zonas mais periféricas da cidade, continua ocorrendo até que na década de 70 , quando 0 fenômeno da favela em São Paulo passou a se desenvolver rapidamente, seguindo o processo de expansão urbana. (SEABRA, 1997).

A urbanização acelerada trouxe aos principais centros industriais (metrópoles) a oportunidade de dividir e lotear as grandes áreas agrárias ao redor do centro, "as quais pela ocupação desordenada e sem nenhuma infra-estrutura denominaramse periferias" (LEMOS, 1999).

Nesse período, as camadas mais pobres da população - e até mesmo os considerados miseráveis - vieram ocupar as áreas mais baratas da cidade, em especial zona sul. Em 1993, 42,51\% da zona sul (que abrange as áreas de mananciais Guarapiranga e Billings) eram ocupadas por favelas. (LEMOS, 1999)

As atividades industriais descentralizaram-se nos anos 90, rumando para outras cidades mais para o interior e eventualmente para outros Estados, deixando de ser os grandes atrativos da cidade de São Paulo.

Assim essa cidade passou a ter um outro papel - o de centralizadora de serviços. Segundo LEMOS (1999) "a metrópole ainda concentra, da mesma forma que no processo de produção industrial, as exigências da network city que organiza ao redor da informatização, a nova estrutura de produção".

\subsubsection{São Paulo - metrópole urbana global}

Encontramo-nos hoje em meio a uma era moderna que perdeu o contato com as raízes de sua própria modernidade. Marx mesmo colocou que o fato básico da vida moderna é radicalmente contraditório em sua base - "os operários são uma invenção dos tempos modernos tanto quanto o maquinismo" (MONTEIRO, 1984).

Os processos globais afetam a estrutura social local das cidades - alterando a organização do trabalho, a distribuição dos ganhos, a estrutura de consumo - e criam novos padrões de desigualdade social urbana. Ao mesmo tempo em que se dispersa no espaço, a economia consolida sua integração na escala planetária. Para SASSEN,(1999) "essa combinação de dispersão geográfica e de integração 
mundial criou um novo papel estratégico para as grandes cidades", que passaram a concentrar funções, alterando as diversas formas de relação entre o homem e 0 espaço (físico e social).

Isso altera a conhecida cidade industrial, desenvolvida até o século passado (XX), e dá oportunidade à era informacional, na qual a globalização aparece como fator de mudança na espacialidade e nos valores das cidades.

Nascem também com isso os conflitos de organização do espaço, levando os lugares a mudar de função e passando a aglomerá-las; criando novas centralidades, baseadas na locação de serviços em diversas áreas da cidade; resultando em uma mudança na divisão espacial.

Neste contexto, observamos a criação de um conflito urbano, no qual a cidade de São Paulo não está na disputa entre valor de uso e valor de troca, mas sim na luta de classes entre incluídos e excluídos da cidade formal. Vale sempre lembrar que, "global" ou não, estamos tratando de uma cidade que mantém cerca de cinco milhões de habitantes, quase metade de sua população, na informalidade habitacional (IBGE, 2000).

Assim, muitas vezes temos a expulsão das classes mais pobres das áreas onde os serviços e a formalidade estão presentes, não respondendo à demanda dessa população pelo direito à cidade, contribuindo para expulsá-la sempre para mais longe, e ultrapassando os limites periféricos até mesmo da cidade informal. (LEFERBVRE, 1969)

Isso significa que os limites da cidade estão aumentando. Na medida em que a cidade cresce, a periferia vai sendo equipada e observamos uma melhora na qualidade da habitação. Ao mesmo tempo, as novas periferias vão sendo produzidas pela ocupação por pessoas excluídas tanto da cidade formal, quanto do que um dia foi periferia e passou a cidade formal dada a sua ocupação. (MALTA, 1994; LEFERBVRE, 1969)

A forma como a cidade é organizada faz com que ela não apenas atraia a população de mais baixa renda, mas que ela própria crie mais gente pobre. Desse modo, o espaço é um instrumento de produção de pobres e de pobreza. A 
tendência à expansão espacial da aglomeração se mantém. Na medida em que a população vai se espraiando ao longo das vias de transporte, e aumentando o tamanho da cidade, os preços da terra e das casas vão normalmente crescendo dentro da cidade. (SANTOS, 1999)

Considerando essa estratificação social e expansão dos habitantes podemos dizer que habitação é um bem seletivo. Boa parte da população não tem renda suficiente para obter um imóvel, sendo esse um dos grandes motivos e sintomas da exclusão social gerando zonas habitacionais das classes alta, média e baixa, industriais e de prestação de serviços. Nessas zonas identificam-se os principais elementos de valorização e de estruturação de uma área (infra-estrutura e as vias de transporte).

A população menos privilegiada monetariamente chega a ocupar até mesmo zonas impróprias para a urbanização, causando problemas ambientais, sociais e econômicos, os quais na verdade são o reflexo do aumento da mancha urbana e da criação da pobreza dentro da própria cidade (SANTOS, 1999). Esse contingente populacional, por vezes, caracteriza-se por uma incessante busca de soluções para poderem sobreviver no espaço urbano, mesmo essas sejam ilegais ou subumanas. Exemplo disso é a atual proliferação dos loteamentos irregulares e as favelas, lugares onde a lei passa ao largo.

É nesse contexto que encontramos nossa área de estudo, englobada na bacia do Guarapiranga, região na periferia da cidade de São Paulo que vem sofrendo urbanização. Antes utilizada como área de lazer, atualmente sofre um tipo de ocupação informal, dada a demanda de moradia das classes excluídas da cidade formal.

Essa ocupação muitas vezes é ilegal, uma vez que se trata de uma área protegida pela lei de uso e ocupação dos mananciais, a qual prevê que o uso do espaço seja compatível com sua importância ambiental (preferencialmente áreas verdes ou de alto padrão).

Como coloca MONTEIRO (1975) "Seja pela implosão demográfica, seja pela implosão das atividades, os espaços urbanos passaram a assumir a 
responsabilidade do impacto máximo da atuação humana sobre a organização na superfície terrestre e na deterioração do ambiente". Causando o problema nessa área que é um recurso natural do qual somos totalmente dependentes, e ao mesmo tempo servindo como opção de moradia para a população da cidade que está em constante crescimento, não condizendo com a sua importância como recurso natural.

\subsubsection{Questão Ambiental}

No mesmo período em que a ocupação urbana vem aumentando na periferia da cidade, a atenção dada ao meio ambiente também vem aumentando. Porém esta talvez tenha chegado um pouco tarde. Passamos a nos preocupar com 0 ambiente quando grande parte já havia sido apropriada e seu uso transformado. É a modernidade em que vivemos: "tudo sempre muda, seja em sua existência física, seja em sua função, tudo está em um movimento constante e dinâmico". (BERMAN, 1987)

A relação mais concreta homem $X$ natureza é a de dependência, que permitiu que nós a enxergássemos como uma coisa, um instrumento. Temos uma percepção de que o homem agride-se contra a sua própria natureza, reprimindo-se para poder ter o domínio dela a seu favor. (BERMAN, 1987). Dessa forma a utilização dos recursos naturais que está sendo tanto mais intensa quanto mais irracional. $E$ a ocupação dessa área natural pelo meio urbano não fica atrás em seu uso intenso e irracional.

Segundo MARCONDES (1999) "a problemática dos mananciais, reside em chegarmos a um consenso quanto a maneira mais eficiente de manter a busca da base ecológica centrada na conservação dos ecossistemas naturais e conciliá-la com a diversidade genética e a relação dessas áreas com as sociedades nas quais estão inseridas".

O que podemos observar pela ampla urbanização e ocupação das áreas de manancial e especialmente a bacia do Guarapiranga é uma visão do espaço físico como neutro na atuação dos diferentes agentes que interagem nos processos de uso e ocupação do solo. 
Esse processo se mostra claro com os dados do SEADE que encontramos em MARCONDES (1999): "No município de São Paulo, observou-se que tanto a área central quanto a intermediária vem perdendo importância, a participação da área central no crescimento da população da capital passou de $16,40 \%$ em 1980 para $12,73 \%$ em 1991, enquanto a área intermediaria a esse percentual passou de $51,64 \%$ para $48,06 \%$. Já a situação da periferia foi bem diferente: o peso na população do município aumentou de 31,96\% para 39,21\% nesse período. É fácil concluir que a população do município de São Paulo está se afastando dos centros para a periferia, extrapolando inclusive seus limites geográficos". O processo de urbanização chega a adquirir contornos em municípios como Itapecerica da Serra e Embu-Guaçu, locais que passaram a abrigar contingentes de população de baixa renda em loteamentos clandestinos e favelas.

A cidade continua crescendo e sua área urbanizada não abriga mais a população, especialmente de baixa renda, assim entramos no conflito social e ambiental que ocorre nas bacias hidrográficas de localização urbana: Ao mesmo tempo que é necessidade ambiental mantê-la para o próprio uso da população urbana, é necessidade social no crescimento e segregação da mancha urbana.

\subsubsection{Leis de recursos hídricos}

O modelo de proteção dos recursos hídricos, adotados no início do século XX até a década de 1930, foi de preservação total dos mananciais, com desapropriação das bacias constituintes do manancial e impedindo, dessa maneira, qualquer tipo de uso ou manejo de seus recursos. Tal medida gerou reservas florestais como o Parque do Estado e Parque da Serra da Cantareira. (CETESB, 1989)

Em 1934, promulgou-se o código das águas, que a declarava propriedade social dos recursos hídricos, desvinculando a propriedade das águas da do uso do solo e estabelecendo normas referentes ao uso das mesmas. Após a década de 1940, essa forma se tornou insustentável, levando em conta os altos preços das terras e a corrente urbanização chegando a essas áreas de manancial, comprometendo os recursos hídricos já escassos. (CETESB, 1989) 
Na década de 1970, foi criada a legislação ambiental de proteção dos mananciais hídricos metropolitanos, que principiam com as leis estaduais (CETESB, 1989):

- 898 de 18/12/1975 que disciplina o uso do solo para a proteção dos mananciais, cursos, reservatórios de água e demais recursos hídricos de interesse da região metropolitana de São Paulo;

- 1172 de 17/11/1976 que delimita as áreas de proteção relativa aos mananciais referentes na lei 898/75, estabelecendo normas e restrições ao uso do solo em tais áreas e tomando providências correlatas;

- Decreto 9714 de 19/04/1977, que institui as competências dos órgãos envolvidos, além dos procedimentos para aprovação dos empreendimentos. Estas foram substituídas por uma lei mais completa e evoluída.

- 9866/97 que estabelece diretrizes e normas para a proteção e recuperação da qualidade ambiental das bacias hidrográficas dos mananciais de interesse regional para abastecimento das populações atuais e futuras do Estado de São Paulo, assegurando, desde que compatíveis, os demais usos múltiplos, considerando mananciais de interesse regional as águas interiores subterrâneas, superficiais, fluentes, emergentes ou em depósito, efetivo ou potencialmente utilizáveis ao abastecimento público.

O que a priori diferencia as leis antigas dessa nova lei é que a de 1997 leva em consideração a grande demanda de urbanização de São Paulo, liberando, de forma regulamentada, a ocupação da área de manancial e dando possibilidade de infra-estrutura para o quase um milhão de habitantes neste tipo de área, em grande parte, instalados em situação ilegal. (SÃO PAULO, 1998 - LEGISLAÇÃO INSTITUTO SÓCIO AMBIENTAL, 1998).

Este novo regulamento deve ser estabelecido pelas diretrizes e normas para a proteção de bacias hidrográficas dos mananciais de interesse regional do estado de São Paulo, editadas pela lei estadual 9866/97. A formulação das leis na década de 1970 insere-se num contexto de planejamento urbano com a tônica do 
pensamento racionalista da organização das grandes estruturas espaciais, distante do contexto atual. (MARCONDES, 1999)

O modelo de proteção dos mananciais da década de 1970 baseou-se na definição de um zoneamento do uso do solo, estabelecendo áreas impróprias a uma ocupação humana tanto urbana como rural. As áreas propícias ao assentamento humano (áreas de segunda categoria) foram estabelecidas a partir de um modelo matemático, com base no cálculo da população equivalente máxima de cada bacia, e conseqüentemente a densidade equivalente à média respectiva ao cálculo dos índices de poluentes gerados. (MARCONDES, 1999)

Vemos então, que a lei hoje aplicada para a proteção de nossos mananciais não condiz com a expansão urbana que ocorreu em São Paulo, a qual, como analisamos, foi realizada quase sem planejamento e direcionada às áreas que contêm mananciais (sul e norte). Atualmente, a discrepância entre lei e realidade é muito mais gritante. Menos confortante, entretanto, é saber que a nova lei, em processo de elaboração e aprovação desde 1997, ainda não evita que os mananciais continuem sofrendo vários tipos de degradação.

\subsection{Unidades Homogêneas da paisagem}

"Pode ser realmente complicado trabalhar no meio urbano com metodologias utilizadas em outras áreas da ciência Por outro lado não se pode negar que 0 ambiente urbano também necessita ter sua utilização planejada, pois uma utilização desordenada constitui numa queda da qualidade de vida". (NUCCl, 2001)

"Desde 1970 o Brasil já pode ser considerado um país urbano (mais de 70\% da sua população mora em cidades), logo vemos uma necessidade de analisar e resolver as questões ambientais, no âmbito de espaços urbanos totalmente construídos ou em construção, e não mais analisando o espaço como ambientes naturais basicamente intocados". NUCCI (2001)

Assim é necessária uma visão intra-urbana da cidade, para um melhor entendimento da mesma. Separando as diversas unidades urbanas, e não mais 
tomando o urbano como algo único, e sim com variantes dentro de uma mesma cidade.

Segundo MONTEIRO (1986) a paisagem é "entidade espacial delimitada, segundo um nível de resolução do pesquisador, a partir dos objetivos centrais da analise, de qualquer modo, sempre o resultado de integração dinâmica e, portanto, instável dos elementos de suporte, forma e cobertura (físicos, biológicos e antrópicos), expressa em parte delimitáveis infinitamente, mas individualizadas através das relações entre elas que organizam um todo complexo (sistema), verdadeiro conjunto solidário em uma perpetua evolução". Assim sendo a cidade pode ser considerada uma paisagem. (apud. NUCCI, 2001)

MARCUS \& DTWYELER (1972) colocam a cidade dividida em dois componentes: O homem e o meio ambiente urbano, e concluem que "o entendimento da dinâmica das interações entre esses dois elementos é facilitada se reconhecermos a cidade como um ecossistema". E SUKOPP \& KUNICK (1973) colocam que "embora as cidades sejam o ambiente mais importante do homem moderno, são esparsas as tentativas de estudá-la e reconhecê-la como unidade funcional (ecossistema)". (apud. Cavalheiro 1991)

"As pressões exercidas pela concentração da população e de atividades geradas pela urbanização e industrialização concorrem para acentuar as modificações do meio ambiente, com o comprometimento da qualidade de vida". As cidades são lugares que apresentam alterações significativas nos recursos naturais como água, solo e ar. MONTEIRO (1987)

Para o entendimento sócio-ambiental de uma área dentro da metrópole de São Paulo, devemos passar não somente pelo físico ambiental, mas principalmente pelo entendimento do urbano.

\subsubsection{Unidades homogêneas urbanas}

O conceito de paisagem foi sendo ampliando nas ultimas décadas, apresentando problemas referentes á heterogeneidade e homogeneidade, com relação à escala 
e as diversas formas da superfície terrestre, ampliando os estudos com relação à superfície terrestre e seus usos.

Dentro do estudo da paisagem, existem várias propostas metodológicas que pretendem fazer a junção da analise do meio físico e ambiental com o urbano. $O$ urbano pode apresentar vários tipos de grupos sociais distintos, desde favelas a áreas nobres, que muitas vezes leva o analista a colocar um indicador médio entre os grupos populacionais diferentes.

A ecologia da paisagem, com o pensamento de McHARG (1971), procura "incorporar os fatores do meio físico no planejamento com base no mapeamento dos fatores intrínsecos do meio ambiente (clima, hidrologia, geologia, solo etc.); e depois combinando os mapas dentro de uma composição que indica por cores a susceptibilidade intrínseca da terra para vários usos, tal como residencial, comercial, industrial, conservação e recreação ativa ou passiva; em adição a composição".

A leitura cartográfica para as paisagens é imprescindível para o entendimento das unidades homogêneas, sendo necessária a "classificação da paisagem em conjuntos de subespaços afins (intra-urbano), de modo a facilitar sua compreensão" (NUCCl, 2001).

Para tanto, devemos confeccionar uma classificação que nos permita elaborar mapas que representem o mais próximo da realidade possível tendo "a unidade de paisagem como uma reapresentação externa do ecossistema. Pode ser entendida como uma síntese de numerosas características que se justificam pela relativa homogeneidade estrutural e funcional. Apresenta qualidades que the conferem uma grande utilidade como unidade operativa de planejamento, como a sua capacidade de reação ou evolução ser a mesma em todos os pontos, o que determinada aptidões e compatibilidades de uso idênticas em toda a sua extensão. Assim, na unidade de paisagem pode se apoiar todo o sistema de recomendações e geração de propostas alternativas de uso do território". (GOMES, 1978) 
GOMES. (opt cit.) utiliza o critério da homogeneidade para a classificação, e afirma que esta pode ser elaborada com procedimentos mais ou menos intuitivos com base em uma apreciação externa da realidade: "quando a prospecção se centra no reconhecimento de ordem e da estrutura do território, o inventário adota a expressão de mapas que representam a classificação do território em unidades intrisincamente homogêneas, ou ambientalmente homogêneas." O autor coloca ainda que a homogeneidade pode ser reduzida a fatores mais importantes. "Na planificação do tipo restritivo é possível delimitar a unidade homogênea, tendo como base apenas uma variável, aquela que exerce maior controle em relação aos objetivos".

Para cada unidade de paisagem definida, tem-se um conjunto de elementos homogêneos que busca ressaltar as relações internas de cada área. As diferenças entre cada uma das unidades se apresentam pelo uso, principalmente antrópico da terra. Já que o homem é o responsável pelo ordenamento, uso do espaço e transformação do mesmo em um pequeno período de tempo.

Tendo em vista os autores acima citados, para podermos entender o sistema urbano não é possível somente separar o que é urbano, temos que entender a dinâmica intra-urbana da cidade, criando áreas homogêneas da mesma e representando-as cartograficamente. Apresentando a "integração dinâmica e individualizada através das relações entre elas". (MONTEIRO 2000).

\subsection{Mapeamento Urbano e ambiental - Geotecnologias}

As paisagens urbanas são compostas por diversos tipos de materiais (concreto, asfalto, plástico, águas, grama, arvores, solo etc.), ordenados pelo homem em meios complexos, como casas, vias de transportes, áreas comerciais, industriais, de recreação entre outros arranjos desses elementos, que são fatores que auxiliam na qualidade de vida urbana. Essas informações são geralmente requeridas pelo poder publico e particular para gerar informações que serão utilizadas nas elaborações de leis, infra-estrutura e zoneamento, criação de meios de transportes entre outros. (JENSEN, 2000) 
LO AND FABER (1998) colocam que uma boa casa, educação escolar, serviços de saúde e um bom meio ambiente físico são indicadores de qualidade de vida, e ajudam os governos a planejar e se envolver na solução de problemas em qualidade de vida em áreas urbanas. Antigamente a maioria dos estudos sobre a qualidade de vida era somente baseados em dados in situ (censo). (apud. JENSEN, 2000)

Só recentemente tem se utilizado os produtos de sensoriamento remoto nessas analises. Esses produtos diferentemente dos dados obtidos em campo em pesquisas de população (censo) nos mostram a quantidade de áreas verdes, distribuição das casas e dos bairros, recuo ao meio fio, tamanho de casas entre outros. Essas informações derivadas do sensoriamento remoto, junto com as informações censitárias, é que nos apresenta os indicadores e do crescimento urbano e da qualidade de vida com maior legitimidade. (JENSEN, J. 2000)

No caso dessa pesquisa, procuramos entender o ambiente com base em fotografias aéreas em ambiente SIG (Sistema de Informações Geográficas).

\subsubsection{Imagens de sensoriamento remoto}

"Sensoriamento Remoto consiste na utilização conjunta instrumentos (sensores), equipamentos para processamento e transmissão de dados e plataformas (aéreas ou espaciais) para carregar tais instrumentos e equipamentos; os resultados dessa coleta tem como objetivo estudar o ambiente terrestre através do registro e da análise das interações entre a radiação eletromagnética e as substâncias componentes do planeta terra, em suas mais diversas manifestações" (Novo, 1989).

\subsubsection{Sistema de Informacões Geográficas}

Os Sistemas de Informação Geográfica (SIG) vêm sendo amplamente utilizados em trabalhos que demandam a articulação de uma grande gama de informações passíveis de espacialização, sendo capazes de trabalhar integradamente os componentes do meio (SANTOS et al., 1998). 
Esses sistemas podem analisar bases de dados que incluem informações cartográficas, espectrais (obtidas por sensores remotos), observações de campo, resultados de entrevistas ou censos, lidando, portanto, com todos os tipos de informações necessárias à decisão: básicas, históricas, atuais e futuras (NORTON \& WALKER, 1985).

Assim, o SIG é um conjunto de instrumentos computacionais composto de equipamentos e programas que por meio de técnicas, integra dados, pessoas e instituições, de forma a tornar possível a coleta, o armazenamento, o processamento, a análise e a disponibilização a partir de dados georreferenciados de informação produzida por meio das aplicações disponíveis, visando maior facilidade, segurança e agilidade nas atividades humanas referentes ao monitoramento, planejamento e tomada de decisões relativas ao espaço geográfico. (NOVO, 1989)

Sendo assim esses são destinados ao tratamento de dados referenciados espacialmente, manipulando dados como mapas, imagens de satélites, fotografias aéreas, cadastros organizando os dados em formas de tabelas e gerando como produto de saída.

Um dado espacial pode ser representado por dois modelos de dados distintos: vetorial ou matricial (raster), esse ultimo é definido por um conjunto de pixels onde cada um possui uma localização. O modelo de dados vetorial é utilizado para representar o espaço como um conjunto de entidades discretas (geoobjetos ou objetos geográficos) definidas por uma unidade (ponto, linha ou polígono) geograficamente referenciada e por seus atributos descritivos. (BURROUGH e MCDONNELI, 1998).

A maioria dos dados gerados por uma aplicação de SIG é apresentada na forma de mapas. Desta maneira, um SIG deve prover funções que são equivalentes àquelas dos sistemas de cartografia automatizada, como colocação automática de rótulos, descrição de legendas e escalas gráficas, entre outras. (LISBOA 2001).

O sensoriamento remoto, juntamente com o SIG nos permite realizar a analise das imagens do sensoriamento remoto, no caso fotografias aéreas. 


\subsubsection{Interpretacão de Imagens}

A interpretação de imagens de sensoriamento remoto foi definida por COLWELL (1983) como o ato de examinar imagens fotográficas de objetos, com o propósito de identificá-los e deduzir seu significado. A interpretação de fotografias aéreas exige conhecimentos técnicos particularmente orientados através da compreensão das ligações entre as formas terrestres e suas correspondentes realidades.

Por outro lado, quando se trata de uma superfície ocupada majoritariamente pelo homem, a fotointerpretação constitui em um excelente recurso para o planejamento regional ou urbano como o de obras para uso do solo, tanto rural como urbano.

Assim, na análise de uma imagem de sensoriamento remoto temos como seqüência para interpretação:

- leitura é a simples leitura da imagem feita a partir a comprovações de campo para então elaborar o overlay através da comparação das imagens em estudo com imagens já interpretadas.

- análise constitui a primeira etapa da fotointerpretação onde se tenta extrair da imagem um conjunto de informações sobre o fato a analisar. $O$ interprete analisa a imagem quanto a características a identificar, ou interpretar como a textura fotográfica, tom, localização espacial, etc. (chave de interpretação)

- interpretação tem como intuito, identificar as principais características de áreas ou objetos, determinando seu significado, que se encontram nas imagens tomadas. Para tanto é necessário adotar uma metodologia de interpretação, para poder-se levantar uma serie de dados e aspectos da área em estudo.

Para fazermos a interpretação dos produtos de sensoriamento remoto temos vários elementos que permitem uma identificação que talvez não fosse tão obvia com esses elementos descritos abaixo podemos formar uma chave de interpretação, conforme definições de CAMPBELL, J. 1944:

- A tonalidade/cor - Seqüência de gradação de do preto para o branco, ou associações de cores. Os contrastes das cores são o que permite a 
representação das características na imagem. Tipicamente as parcelas de cobertura da terra são delimitadas por linhas que tem mais ou menos cores uniformes.

- A tonalidade em fotografias preta e branca (a cor em fotografias coloridas) pode indicar as condições do solo, o tipo de cultura, o estágio de crescimento e vigor das mesmas, claro que variando de acordo com as condições das fotografias, não podendo ser visto como meio absoluto da interpretação.

- A cor apresenta maior variação nas fotografias aéreas. A variação das cores dá-se pelos vários estágios de desenvolvimento como em cultivos, exposição do solo etc.

- A textura - é a distinção visual da impressão de rugosidade ou de superfície lisa, causada pela variabilidade ou uniformidade da tonalidade da imagem. Textura se aplica a áreas (mais que a objetos individuais), sendo uma ótima propriedade para identificação de tipos de coberturas de terra.

- Características de áreas de florestas são comumente associadas à textura da imagem. Texturas lisas são associadas com florestas jovens, assim como rugosas florestas mais antigas, por exemplo.

- Forma - A forma é a delimitação geométrica de uma área, a forma permite distinguir características Formas regulares normalmente são antrópicas, e formas irregulares normalmente são naturais.

- Dimensão - A dimensão dos objetos são muito usuais na identificação. Ela apresenta o tamanho de um objeto ou área. Raramente é necessário fazer uma medição da dimensão para a identificação, é claro que o tamanho, principalmente das parcelas de terra, são necessários para a distinção das características, associadas as comparações entre as áreas.

- Sombras - É a parte da foto onde não há refletância. As sombras são tradicionalmente um dos mais importantes fatores na identificação de objetos na interpretação de fotografias aéreas, porque ela revela a silhueta dos 
objetos. $\mathrm{Na}$ interpretação de uso da terra as sombras são importantes para realçar fronteiras entre categorias, contribuindo para as diferenças texturiais. Por exemplo, a área de contato entre um campo aberto e uma floresta, se iluminado pelo lado da floresta, será marcado pela sombra da floresta, quando visto de cima essa sombra forma uma linha entre as duas áreas, demarcando a fronteira.

Para realizarmos a interpretação de imagens de sensoriamento remoto temos a necessidade de criar uma chave que interpretação seguindo os fatores acima. Essa chave nos possibilita a interpretação da imagem em estudo de um modo único, os mapas são confeccionados com base na interpretação, e é passível de ser replicada em outras imagens, de outros anos, por exemplo, tendo uma analise dinâmica da área.

\subsubsection{Fotografias aéreas}

É um dos produtos do sensoriamento remoto, é obtida como uma imagem fotográfica onde as feições nela contidas são apresentadas em suas verdadeiras posições, sendo desta forma, uma projeção central.

O princípio básico de produção de ortofotocartas digitais consiste no processo de transformação da projeção central na imagem (fotografia da aérea rasterizada) em projeção ortogonal ao plano, mediante meios e métodos essencialmente digitais. (ARAúJO, 1991)

Os elementos básicos necessários para a geração de uma ortofotocarta digital, são: imagem digital, pontos de controle, modelo digital do terreno e parâmetros da câmara. (ARAÚJO, 1991)

Caso as fotografias já estejam disponíveis, é possível fazer o mapeamento e criação das ortofotocartas digitais, desde que o levantamento aerofotogramétrico atenda geométrica e radiometricamente os quesitos básicos para mapeamento.

Para que possa ser obtida faz-se necessário à correlação da imagem com o terreno fotografado. Esta adequação é feita por meio do processo de aerotriangulação. Para a realização da aerotriangulação, é necessária a obtenção 
de coordenadas de alguns pontos do terreno, chamados pontos de apoio. Usualmente são requeridos apenas dois pontos a cada três modelos fotogramétricos. As coordenadas planimétricas dos pontos de apoio são obtidas por métodos de levantamento, por rastreamento de satélites GPS (Global Positioning System) e as coordenadas altimétricas por nivelamento geométrico. (FURQUIM et al,1996; ARAÚJO, 1991).

Para a área a ser coberta pelas ortofotografias devemos preparar um modelo digital do terreno. Isto significa que as altitudes, as quais estão arranjadas em uma malha regular, têm que representar o terreno. Valores de altitude para cada pixel da ortofoto devem ser interpolados. (FURQUIM et al; 1996; MANDANI, 19?)

Assim a ortofotocarta se apresenta como uma única imagem das fotografias relativas às áreas. Essa ortofotocarta é bastante usada para a criação de mapas que serão gerados a partir da interpretação, em meios digitais gerada em ambiente SIG.

\subsubsection{Censo Demográfico}

Um censo é um processo de obter informação sobre a totalidade dos membros de uma dada população (não tem de ser, necessariamente, uma população humana). (IBGE, 2003)

O Censo Demográfico é a única pesquisa domiciliar que produz resultados para o universo da população, independente do nível de desagregação espacial. Tais resultados têm validade para as Unidades da Federação, os Municípios, Distritos e, até, com uma precisão cada vez maior, para os bairros e outros recortes espaciais que podem ser formados pela agregação de setores censitários. È de suma importância como instrumento de avaliação da realidade demográfica e socioeconômica do país, destacando-se aí os municípios, e como elemento básico para subsidiar e orientar as políticas atuais e futuras no nível local. (IBGE, 2003)

O Censo de 2000 foi o primeiro que o IBGE (Instituto Brasileiro de Geografia e Estatística) disponibilizou sob forma de dados digitais, que podem ser utilizados 
em ambientes SIGs, já que estes passaram a ser comumente utilizados em meios de cartografia e planejamento de mercado.

O IBGE disponibiliza para o censo de 2000 , cds com dados agregados por setores censitários, para varias cidades do Brasil, com mapas digitais para cidades com população acima de 25 mil habitantes.

Setor censitário é uma área delimitada pelo IBGE, e é a menor unidade disponível em meio digital em formato mapa oficialmente no Brasil. Essa área corresponde a conjuntos de até 200 domicílios, a figura 1 mostra algumas áreas de setores censitários. O censor visita essas áreas e aplica o questionário, que depois é agrupado por esses domicílios para termos a informação consolidada dessa área, de modo a preservar a identidade dos domicílios entrevistados. Assim, trabalhamos com uma media dos dados daquela área. (IBGE, 2003).

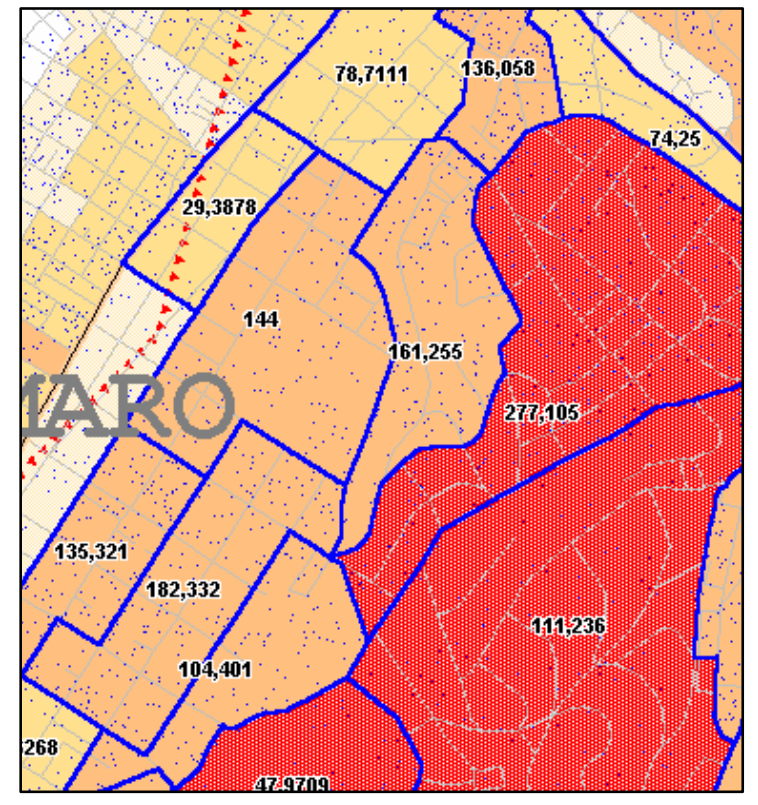

\section{Figura 1 - Setor Censitário}

O IBGE disponibiliza mapas e dados de cada setor censitário, por vários tipos de dados - domicílios, renda, intrusão e população. Nessa pesquisa estamos trabalhando com domicílios, renda e população.

No caso dos domicílios, iremos trabalhar com domicílios particulares permanentes, que se distinguem do total de domicílios. Domicílios totais podem ser locais estruturalmente separados e independentes e que se destinam a servir de 
habitação a uma ou mais pessoas, ou que esteja sendo utilizado como tal. Ainda caracterizado quando o local de habitação tem acesso direto, permitindo a seus moradores entrarem e saírem sem a necessidade de passar por locais de moradia de outras pessoas, localizados em unidades não-residenciais (loja, fabrica etc), que não tenham dependências exclusivamente para moradia, mas que é ocupada por morador. (IBGE, 2003).

Já os domicílios particulares permanentes são domicílios únicos, onde seus ocupantes têm o relacionamento ditado por laços de parentesco, de dependência doméstica ou por normas de convivência; construídos para servir exclusivamente à habitação e na data da referencia, tinha a finalidade de servir de moradia a uma ou mais pessoas. (IBGE, 2003).

Assim temos que os domicílios particulares permanentes apontam para moradia, enquanto os domicílios totais agregam outros tipos, por isso a escolha dos particulares permanentes que mostram a situação das residências da área de estudo.

A renda é apresentada por salários mínimos, e por se tratar de um dado de 2000 temos que utilizar o valor do salário mínimo de 2000, 151 reais.

O rendimento da pesquisa do IBGE é o rendimento nominal mensal, da pessoa acima de 10 anos de idade, responsável pelo domicilio particular permanente, a soma do rendimento nominal mensal de trabalho com o proveniente de outras fontes (IBGE, 2003). Sendo que o rendimento de trabalho foi tudo dos trabalhos que a pessoa tinha na semana de referencia, que foi de 23 a 29 de julho de 2000 , considerou-se a remuneração bruta ou a retirada do mês de julho de 2000. E outras fontes, podem ser aposentadoria, pensão aluguel etc. Entendendo por remuneração bruta o pagamento sem excluir os descontos correspondentes aos institutos de previdência oficial, impostos de renda, faltas etc. e sem incluir o $13^{\circ}$ salário, a gratificação de férias e participação de lucros pagos por empregador. (IBGE, 2003).

Esse rendimento nominal mensal foi dividido em classes de salários mínimos para criar classes de renda por domicilio, já que cada domicílio particular permanente 
tem somente um responsável. Assim, a renda mensal pode ser obtida pela divisão da renda nominal mensal total / domicílios particulares permanentes; assim temos o rendimento médio dos domicílios em um setor censitário.

Como as variáveis do censo do IBGE são para o ano de 2000, podemos manter uma lógica espaço-temporal dos dados, tornando assim sua analise mais correta.

\section{A área de estudo - dinâmica e expansão urbana}

A dinâmica de uso e apropriação do espaço da Bacia do Guarapiranga é marcada pelo fato de ser limítrofe com regiões de grande valia na reprodução econômica do espaço que é a região metropolitana de São Paulo, com grande presença de atividade terciária e até industrial além de desenvolvidos sistemas de transporte. "A localização singular desse manancial hídrico tem pautado o conflito entre o uso do solo urbano e a proteção dos recursos ambientais na metrópole paulista". (MARCONDES, 1999)

A grande característica dessa área ainda é ser um manancial de abastecimento de água. Porém sua localização singular dá a esse reservatório uma importância global no sistema de abastecimento de água de São Paulo.

Outro fator importante dessa bacia é o de ser um reduto dos remanescentes florestais da cidade, uma divisão entre a área urbanizada e o parque da Serra do Mar. Sendo importante para a manutenção da pluviosidade, condições climatológicas e preservação de área de vegetação natural. (MARCONDES, 1999).

Ainda por ser uma área distante do centro de São Paulo torna-se de maior importância social e urbana, já que a cidade vem crescendo nessa direção, dada a segregação da população de renda mais baixa. Assim além de ambientalmente importante, a bacia do Guarapiranga é uma área socialmente importante. Tornando o uso do espaço conflitante.

\subsection{Aspectos do ambiente natural}

Abrangendo uma área de $637 \mathrm{~km}^{2}$, distribuída em seis municípios: Embu-Guaçu, Embu, Itapecerica da Serra, Cotia, Juquitiba, e parte sul de São Paulo (cerca de 
$40 \mathrm{~km}$ do centro urbano); a bacia do Guarapiranga possui acesso ao centro urbano (imediações da avenida paulista) pela estrada de Guarapiranga e M-Boi Mirim, que são as principais vias dessa região que levam á estrada de Embu, regiões rurais do município de São Paulo, e aos municípios vizinhos.Nossa área de estudo não abrange a totalidade da bacia, e sim uma parte da mesma, como vemos na figura 2 .

A área de estudos possui alta densidade de drenagem. Tal configuração confere ao local uma disposição do terreno que segue o entalhe fluvial; temos uma série de vertentes predominantemente convexas, com vales encaixados de fundo chato e faixas de declividade altas. (Vilela; Ross, 2003)

Do ponto de vista geológico e geomorfológico a Bacia do Guarapiranga é marca pela transição sedimentar entre a Bacia Sedimentar de São Paulo e os terrenos cristalinos que a circundam, a litologia dominante na área de estudos é gnáissica. O relevo dispõe-se de forma alveolar, com altimétrias variando de 750 a quase 900 metros, havendo um divisor de águas maior (onde está a Estrada do M'Boi Mirim, com dimensão interfluvial média de 250 metros), formando em sua crista alongada vertentes com patamares planos e inclinados, que à medida que caem para sul vão ganhando formas convexas. (Vilela, F.; Ross, J. ,2003)

Os sedimentos terciários (formações S. Paulo e Resende) se estendem por toda a área central do município de São Paulo, sendo o espigão da Paulista sustentado pela Formação São Paulo, e em manchas isoladas ao sul, entre as represas Guarapiranga e Billings, Quanto à formação geológica, apresenta maciços do complexo cristalino (gnaisses, granito, e mistos de xisto-granítico) com alguns enclaves da Formação São Paulo (IPT, 1993). As formações graníticas apresentam um relevo acidentado que favorece a erosão, já que aumenta a velocidade de escoamento das águas superficiais.

TARIFA e ARMANI (2001) colocam que nas regiões das bacias Billings e Guarapiranga temos o clima sub-tropical superúmido onde se observa grande influencia oceânica, grande instabilidade temperatura média entre 19,3 e 19,6 
pluviosidade total anual entre 1400 - 1800 mm, máximas diárias entre 200 e 400 $\mathrm{mm}$ com nevoeiros e baixo estratos freqüentes.

A área é quase totalmente urbanizada e se caracteriza como um típico bairro dormitório da periferia que além da alta densidade possui inúmeras habitações precárias e problemas de infra-estrutura, transporte coletivo, áreas de lazer, água servida correndo a céu aberto. Todavia é oficialmente servida por rede de esgoto em sua quase totalidade. O sistema Viário é praticamente inteiro de asfalto ou blocos intertravados. (SEHAB - CONSORCIO JNS/HAGAPLAN 1998)

$\mathrm{Na}$ margem direita ao reservatório encontramos solos aluvionais e planícies aluviais restritas, assim como na margem esquerda, esses tipos de solo possuem potencial erosivo alto em declividades medias e altas. Na área também temos solos hidromorficos correspondentes a sedimentos aluviais (argila, areia e cascalho) nos terrenos planos junto as principais linhas de drenagem. (SEHAB CONSORCIO JNS/HAGAPLAN 1998)

Pesam aqui os aspectos da má qualidade e péssima manutenção do asfaltamento realizado. Não existem grandes problemas quanto ao desenho das vias, seja nas curvaturas, nas declividades ou nas suas inclinações. E a rede elétrica atende a totalidade da área de estudo, bem como a iluminação pública. Afora o aspecto precário e a má qualidade das ligações aqui se encontram os melhores níveis de manutenção e de funcionamento em relação às demais infra-estruturas instaladas. (SEHAB - CONSORCIO JNS/HAGAPLAN 1998)

Também existem na região Loteamentos de Alto Padrão, como Chácaras e Marinas que são usados para lazer, alem de clubes, restaurantes e outros pontos comerciais; sendo que todos estes se apresentam em menor numero do que as favelas e loteamentos irregulares.

Com relação às favelas, $80 \%$ estão concentradas no município de São Paulo, nas margens esquerda e direita do reservatório, estendendo-se sobre os córregos de contribuição direta; $12 \%$ em Embu e $8 \%$ em Itapecerica da Serra, tendo participação direta no processo de poluição e degradação de rio Embu-Mirim, um dos principais formadores do reservatório. Elas também ocupam área de 
topografia irregular (altas declividades), necessitando a construção de escadas e muro de arrimo para deter a erosão e o escorregamento de encostas.

Já os loteamentos clandestinos encontram-se espalhados por toda a região da bacia, sendo em maior numero na parte norte da mesma, o poder público constatou 200 loteamentos clandestinos. (SEHAB - CONSORCIO JNS/HAGAPLAN 1998)

Nossa área de estudo é um recorte da bacia do Guarapiranga, e encontra-se na zona sul da cidade de São Paulo, abrangendo alguns municípios da RMSP (Região Metropolitana de São Paulo) - Itapecerica da Serra e Embu-Guaçu, como mostra a figura 2 .

O centro da nossa área de estudo é parte do reservatório Guarapiranga, e ao redor temos áreas urbanamente ocupadas como vemos na figura 3.

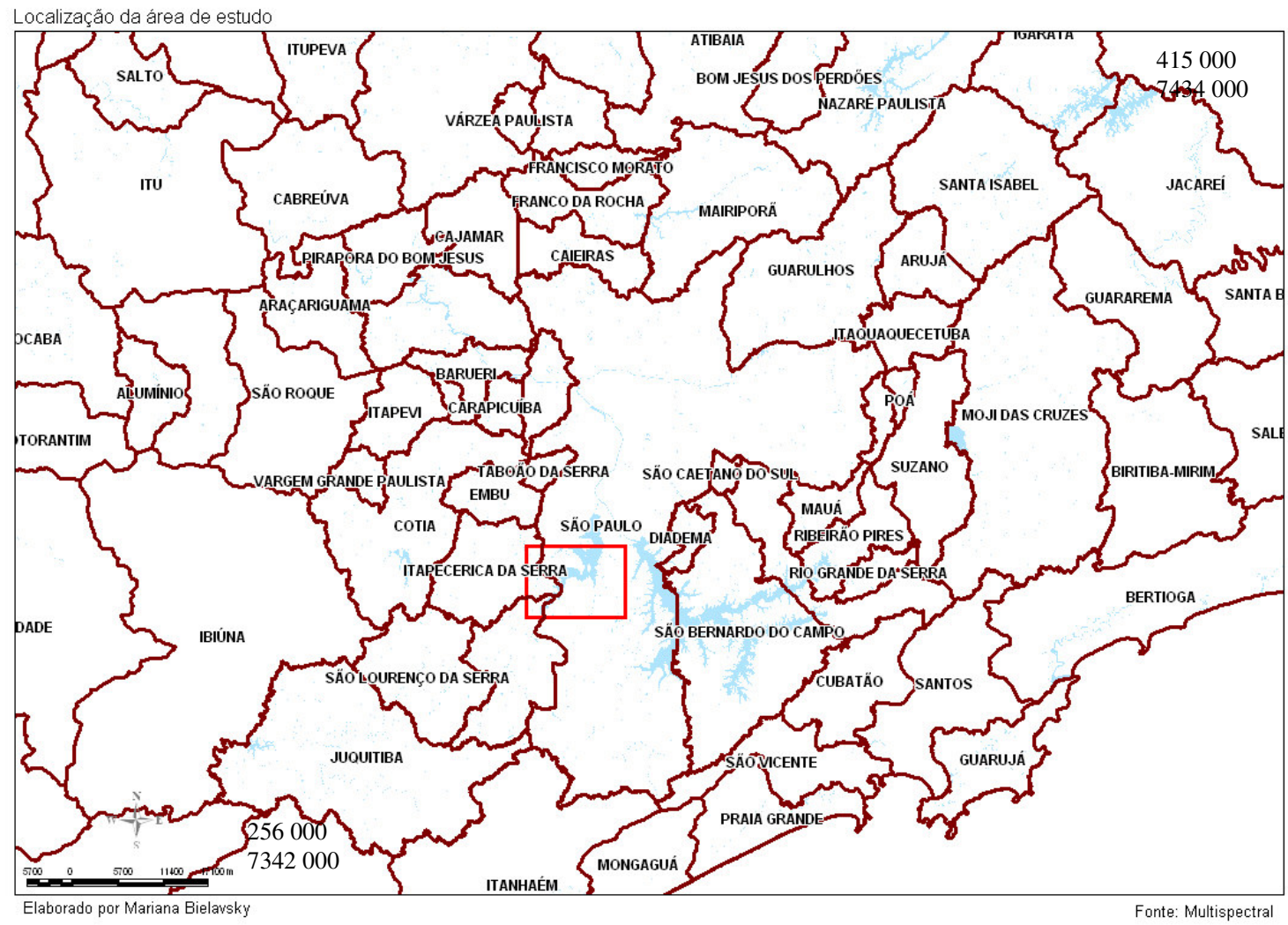

Figura 2 Localização da área de estudo em São Paulo 


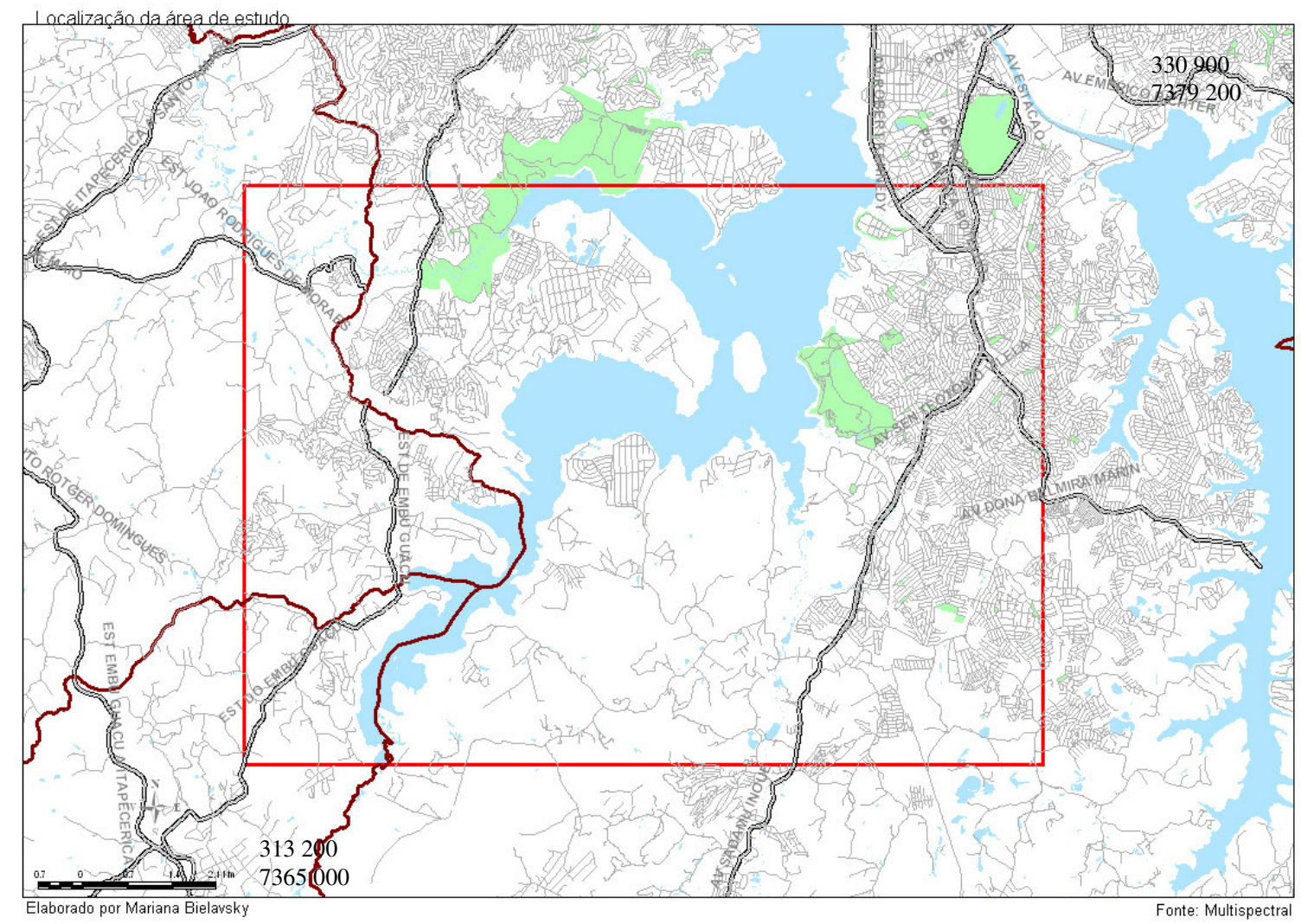

Figura 3 - Localização da área de estudo - viário de São Paulo

\subsection{Resultados - Dinâmica de crescimento (60 a 94)}

Para obtermos a dinâmica do uso da terra em um período de 40 anos, utilizamos a interpretação de fotografias aéreas da área do reservatório para os anos de 1962, 1974 e 1994. Todas essas fotografias foram obtidas em papel que foram escaneadas a fim de podermos trabalhá-las em meio digital.

Com as fotografias digitalizadas, o primeiro processo foi o georreferenciamento, partindo da base de eixos de ruas das três cidades em estudo. Com todas as fotografias georreferenciadas, confeccionamos o mosaico delas, que é o aproveitamento de $60 \%$ de cada foto, já que elas se sobrepõem nos demais $40 \%$.

Para finalizar a facção da orotfotocarta elaboramos um modelo do terreno com a carta de declividade, de modo a realizarmos as ultimas correções sobre a posição real de cada foto no espaço. 
A analise da ortofotocarta nos permitiu obter o mapa de uso da terra para os três anos acima citados. Como a qualidade da foto digitalizada não permite uma resolução de imagem muito boa, não foi possível nesse momento uma interpretação mais detalhada dos usos da terra.

Abaixo segue a chave de interpretação, onde temos os principais usos da terra:

- Vegetação

- Campo - onde predominam espécies arbustivas e poucas espécies arbóreas,

- Capoeira - vegetação arbustiva

- Mata - espécies arbóreas adultas

- Loteamentos - área grande é dividida em varias áreas de ocupação urbana que pode ser de vários tipos:

- Alto padrão lotes com baixa taxa de ocupação, geralmente de $30 \%$ do terreno.

- Residências horizontais, sendo a construção de apenas uma edificação por lote. (MARCONDES, 1999) Além de serem de boa adequação para a área ocupada e para os moradores.

- Chácaras que tem a área ocupada menor que o lote e muitas vezes conservando a vegetação original do mesmo.

- Médio padrão:

- Adensamento de edificações.

- verticalização mesmo que em pouca quantidade, ou seja, a área ocupada vem a ser maior que a do lote.

- A construção ocupa geralmente por volta de $50 \%$ do terreno.

- Adensamento populacional e de construções maior que no loteamento de alto padrão. 
- Baixo padrão:

- Favelas - As favelas se caracterizam por ocupar áreas não adquiridas, públicas ou privadas, sobre as quais são edificadas habitações precárias, de modo a apresentarmos polígonos de áreas grandes. (Rolnik, 1991, 1992)

- Autoconstrução - contrariam normas de parcelamento e uso do solo que regem a ocupação do espaço no município. (Rolnik, 1991, 1992)

- Alta taxa de ocupação com relação ao coeficiente de aproveitamento, ou seja, há uma ocupação da totalidade do terreno, muitas vezes existindo prédios que adensam a ocupação. Essa alta taxa é fator da baixa permeabilidade do solo além da escassez de recursos como iluminação e saneamento.

- Loteamentos de baixo padrão apresentam deficiência em infra-estrutura, saneamento, sistema viário, equipamentos sociais (como escola e postos de saúde) entre outros.

- Clube, escola e área de lazer:

- lotes destinados a uso coletivo e de área grande

- Baixa densidade de ocupação, podendo haver a implantação de restaurantes, serviços de aluguel de barcos, e outras atividades afins.

Para fazer a distinção entre os tipos de loteamentos nas imagens, primeiramente foi interpretada a mancha urbana. Ampliando-se a visualização da área pode-se identificar o tamanho dos lotes e a taxa de ocupação dos mesmos. Por fim podese identificar a ocupação destes, elaborar estimativas de porcentagem de construção e adensamento dos mesmos. 


\subsubsection{Uso da terra em 1962}

Podemos observar pelo mapa de uso do solo de 1962 (figura 4) que a área nessa época tinha uma ocupação basicamente de vegetação e urbana de alto padrão.

Era uma área considerada de lazer, por isso a grande quantidade de chácaras; marinas e clubes; além dos loteamentos de alto padrão. Essa ocupação mostra que as pessoas procuravam beleza paisagística e um local com grande quantidade de vegetação e pouca habitação, sendo uma área de descanso e lazer para as pessoas.

Nesse período já havia uma mineração de areia e argila demonstrando que mesmo pouco ocupada a área já apresentava exploração de seus recursos. Além das ocupações de médio padrão, já denotando a procura dessa área para habitação não voltada ao lazer.

Podemos observar que a pouca ocupação urbana de loteamentos que havia na área já se concentrava na região leste e oeste tendo a represa como centro do mapa. A área sul é mais ocupada por chácaras e loteamentos de alto padrão, mostrando a busca dessa gama de população por lazer e não por moradia fixa. 


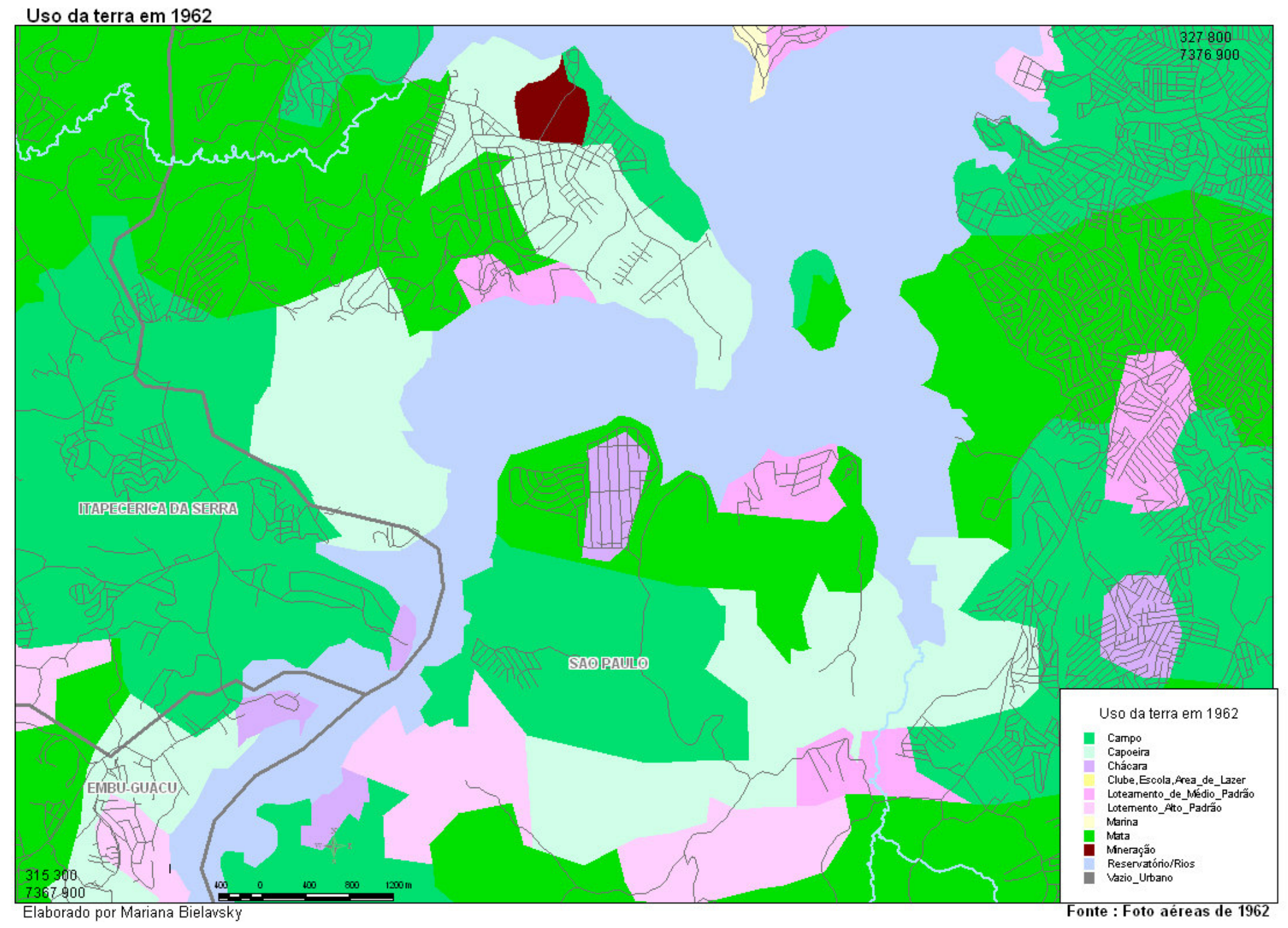

Figura 4 - Uso da terra em 1962 


\subsubsection{Uso da terra em 1974}

Pelo mapa que o uso da terra vemos que a área possui mais loteamentos urbanos, principalmente de médio e baixo padrão, em detrimento a ocupação de 1962 (figura 4), Porém a urbanização ainda não se mostra intensa na área de estudo.

Os loteamentos se encontram bastante dispersos pela área, mas já vemos um foco de ocupação de baixo padrão na área leste da carta (figura 4). A oeste do também podemos observar o adensamento de áreas de médio e baixo padrão, ocupando áreas que antes eram de alto padrão e chácaras, isso ocorre dada a desvalorização da terra, houve um loteamento dessas áreas que dão origem a um uso por populações economicamente desprivilegiadas, (mapa de uso da terra 1962 - figura 4), mostrando assim a mudança do uso da terra e do tipo da população ocupante.

Ao norte podemos observar a marina que se encontra desde 1962 (figura 3), assim como uma área de lazer e a mineração, que tem seu tamanho aumentado nesse ano de 1974 (figura 5).

Ao sul a ocupação continua sendo menos densa, e em sua maior parte de vegetação, essa em sua maior parte de capoeira (as margens da represa) e campo com alguns polígonos que representam a mata natural.

$\mathrm{Na}$ área, ainda existem algumas culturas próximas principalmente ás chácaras, e poucas áreas de lazer, mostrando a alteração do uso da área, que deixa de ser de lazer para começar a se tornar de ocupação urbana, como meio de moradia para as classes de mais baixa renda.

O que observamos são os vetores de ocupação da área, principalmente por população de baixa renda. Esses vetores encontram-se a leste e a oeste, observamo-nos quando comparamos as duas cartas (ilustrações 4 e 5) o crescimento da urbanização em que a população deixa de ver a área como uma busca de lazer e passa a vê-la como moradia fixa, dá-se nessas principalmente nessas duas regiões. Que por sua vez passam a apresentar um nível de infra- 
estrutura maior com grandes avenidas, vias de acesso e ate mesmo a linha de trem da CPTM (Companhia Paulista de Trens Metropolitanos). 


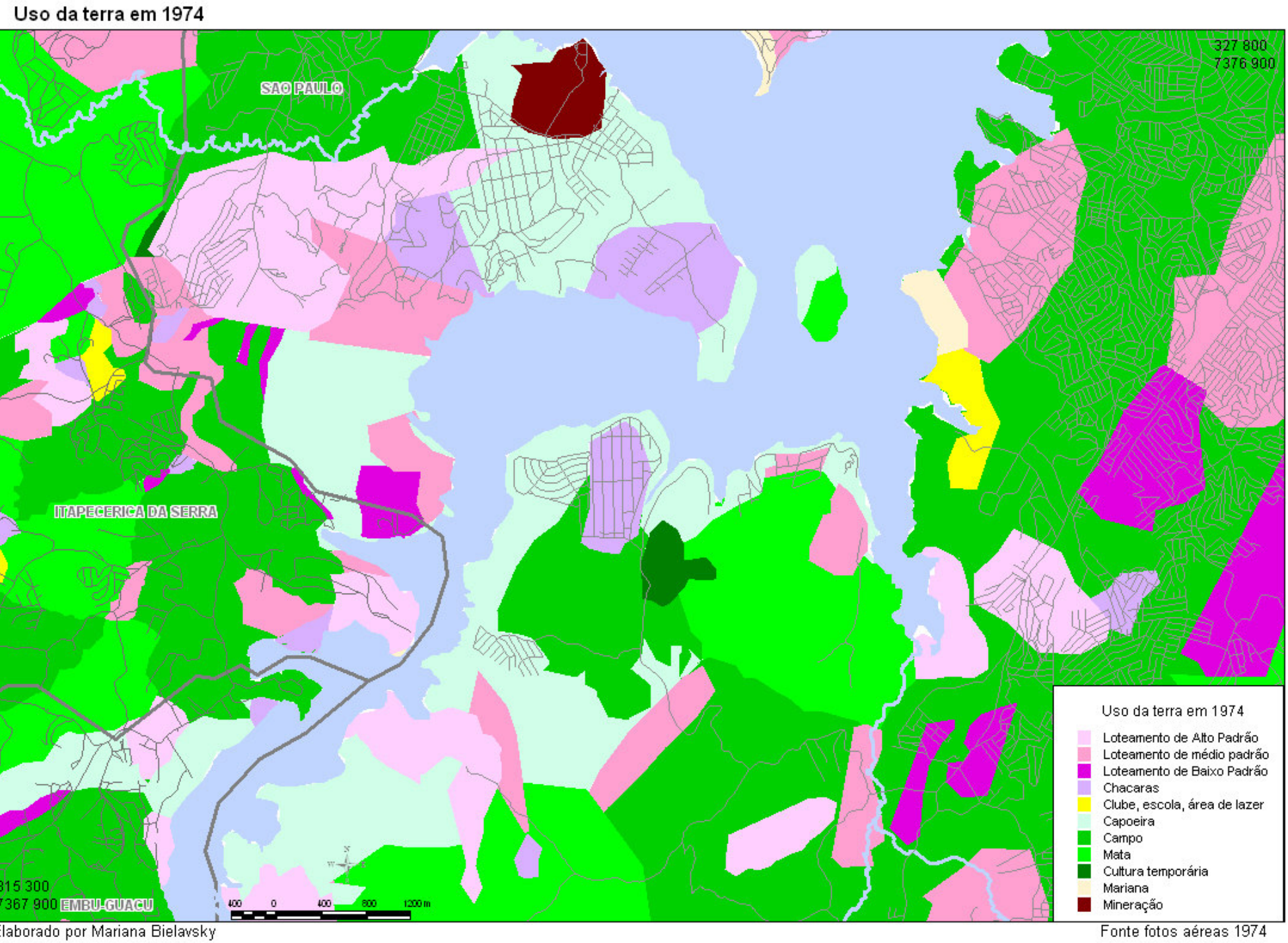

Figura 5 - Uso da terra em 1974 


\subsubsection{Uso da terra 1994}

Para o ano de 1994 (figura 6) podemos observar um aumento do uso urbano de moradia fixa na área, principalmente nas áreas leste e oeste.

Nessa época temos um uso bastante misturado, entre a vegetação e o uso urbano. O que mostra a mudança de uso nessa região, tornando-se predominantemente urbana e não mais de vegetação como mostra a figura 34 , 0 uso da terra em 1962.

A região sul da represa é muito pouco alterada entre 1962 e 1994 (ilustrações 4 e 6 respectivamente), mantendo-se com usos de vegetação e urbano como chácaras e loteamentos de alto padrão.

A alteração significativa que temos para o ano de 1994 é o adensamento urbano com loteamentos de médio e baixo padrão principalmente na área leste a represa. Havendo também um certo aumento de urbanização de moradia fixa a oeste da represa.

O que podemos observar ao fim da análise dessas três cartas, é a existência dos vetores de urbanização a leste e a oeste da represa. Desde de 1962 a área vem tomando forma de adensamento urbano de moradia fixa de população de baixa renda nessas áreas do reservatório; e mantendo um uso de vegetação na região sul do mesmo.

Infelizmente não temos o sistema viário para os anos em estudo, estamos sempre trabalhando com o sistema viário para 2001. Não é possível perceber o avanço do transporte nessa região. Porém o viário de 2001 nos permite verificar que realmente essas duas regiões foram as que progrediram em termos de acesso, são onde ocorrem mais vias e mais vias principais de acesso. Ao sul existem poucas ruas que em geral circundam as áreas de chácaras e loteamentos de alto padrão, realmente só para o acesso a essas e não uma infra-estrutura viária.

Em vista a esses vetores de urbanização que abrangem a leste o bairro da cidade de São Paulo Jardim Ângela, e a oeste Pedreira e Grajaú. Bairros urbanizados e 
ocupados por pessoas de baixa renda e muitas vezes em tipos de ocupação de favelas, de autoconstruções em áreas impróprias.

Tendo em vista esse crescimento da cidade é que passamos a uma analise intraurbana da área, onde poderemos verificar para o ano de 2001 o tipo de uso intraurbano, existência de comercio e indústrias e serviços e infra-estrutura demográfica. Esses últimos obtidos por dados do censo do ano 2000 realizado pelo IBGE. 


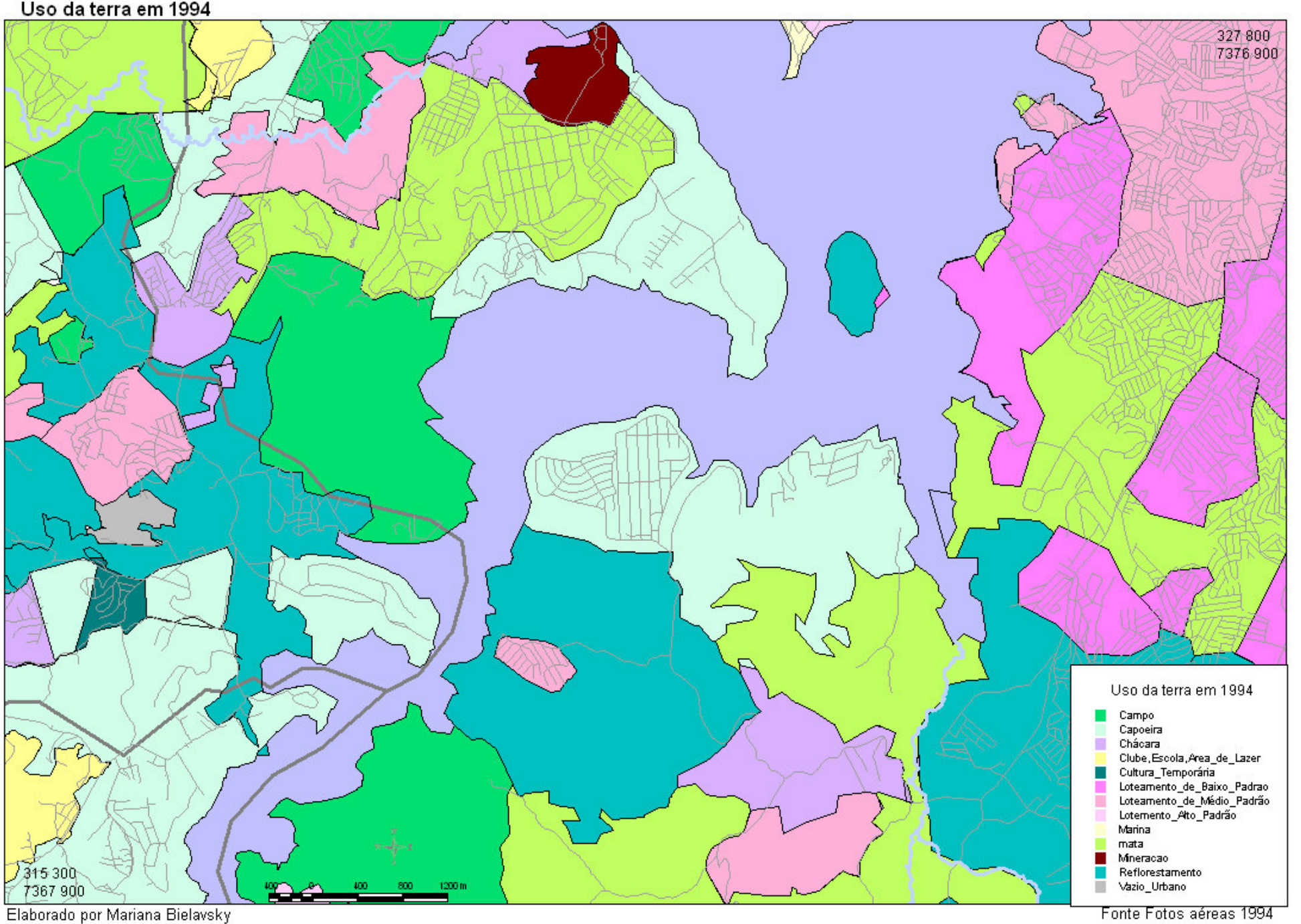

Figura 6 - Uso da terra em 1994 


\section{5. Áreas homogêneas urbanas (2001)}

Com a analise da fotografia podemos interpretar o uso da terra para o ano de 2001 levantando os aspectos intra-urbanos da área, e acrescendo-se os dados do censo, podemos obter uma analise mais completa do tipo de uso. Verificando não só para onde cresce a cidade, e também como e com que qualidade ela cresce.

Para a carta de áreas homogêneas urbanas de 2001, iremos trabalhamos somente com o município de São Paulo, já que as fotografias áreas cedidas são somente para esse município (englobando uma pequena parte dos municípios vizinhos que o vôo abrangeu). Como a maior parte da área de estudo se encontra em São Paulo, acreditamos não haver perdas.

Fez-se o georreferenciamento e a elaboração da ortofotocarta para as fotografias área de 2001. Esses são feitos em ambiente SIG: obtemos primeiro o georreferenciamento a partir de uma base digital já georreferenciada, no caso o sistema viário. Pela foto observamos a formação das ruas, e atribuímos essa parte da foto a rua em questão conforme figura abaixo (escala primeira figura 1:20 000, segunda 1:30 000): 


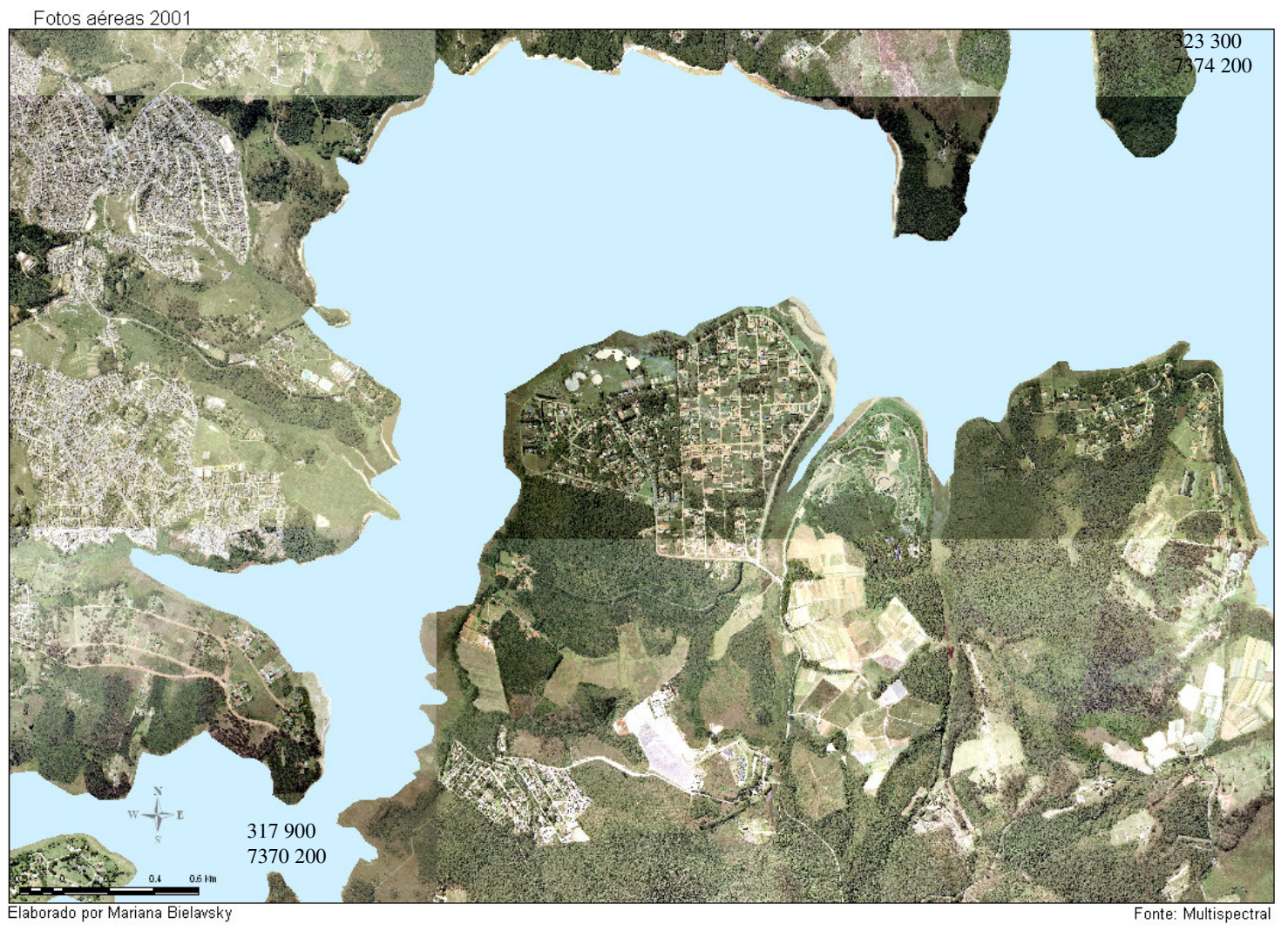

Figura 7 - Ortofotocarta georreferenciada 
Com as fotografias georreferenciadas, foi possível fazer a orotofotocarta, que é o fato de colarmos as partes das fotografias em um único mapa. Isso é feito, pois somente $60 \%$ das fotografias são únicas, podendo assim ser ligadas em faixas horizontais e verticais.

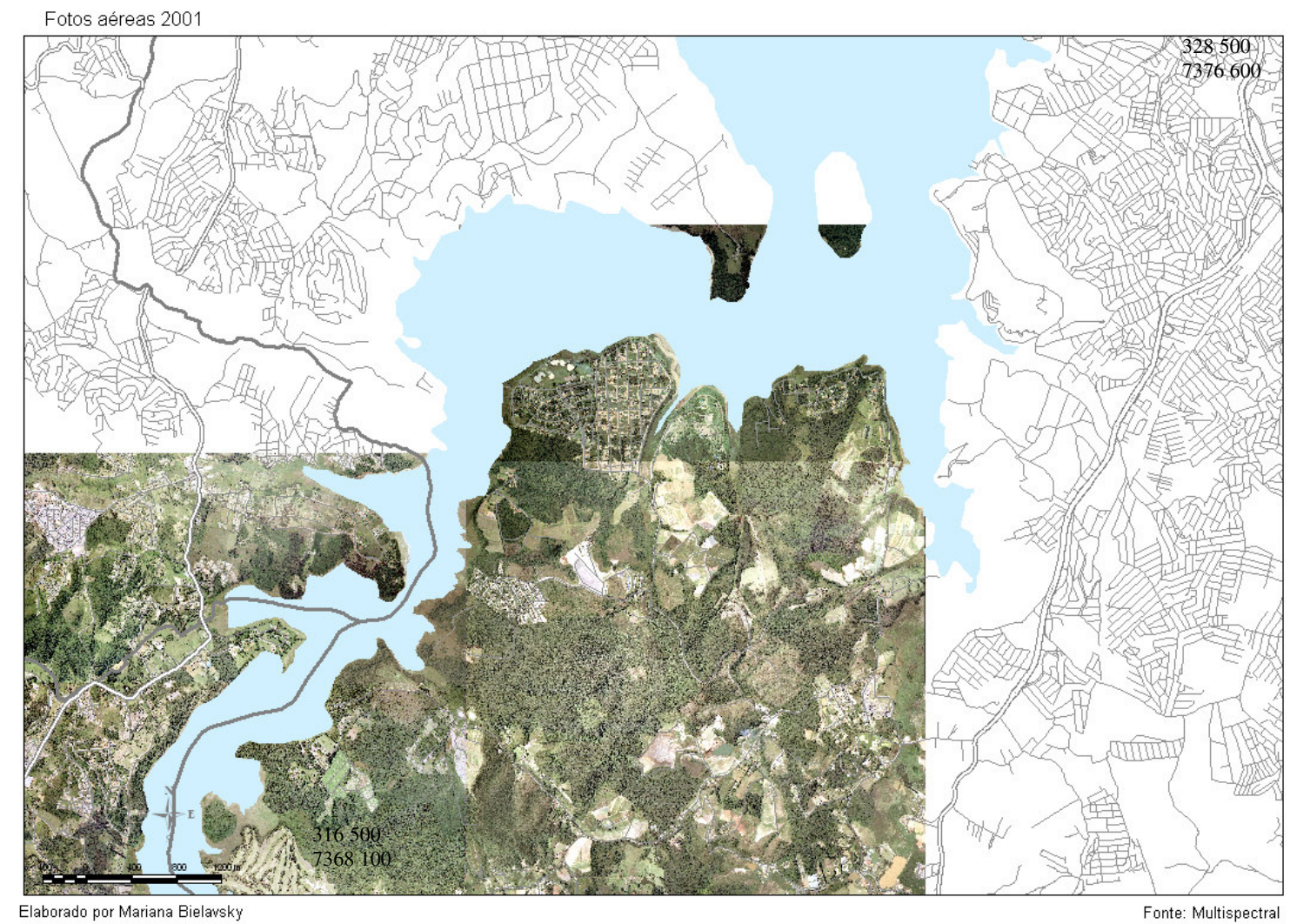

Figura 8 - Localização de parte da orotofotocarta

Como o vôo realizado pela empresa Multispectral foi para obter uma escala de 1:15 000 e a altura do vôo de aproximadamente 2300 metros, a qualidade da foto nos permite uma ampliação de aproximação máxima de 1:5000 com definição máxima de $5 \times 5 \mathrm{~m}$ por pixel, como mostra a figura 9 . Mais que isso a qualidade da fotografia abaixa e sua interpretação fica confusa. 


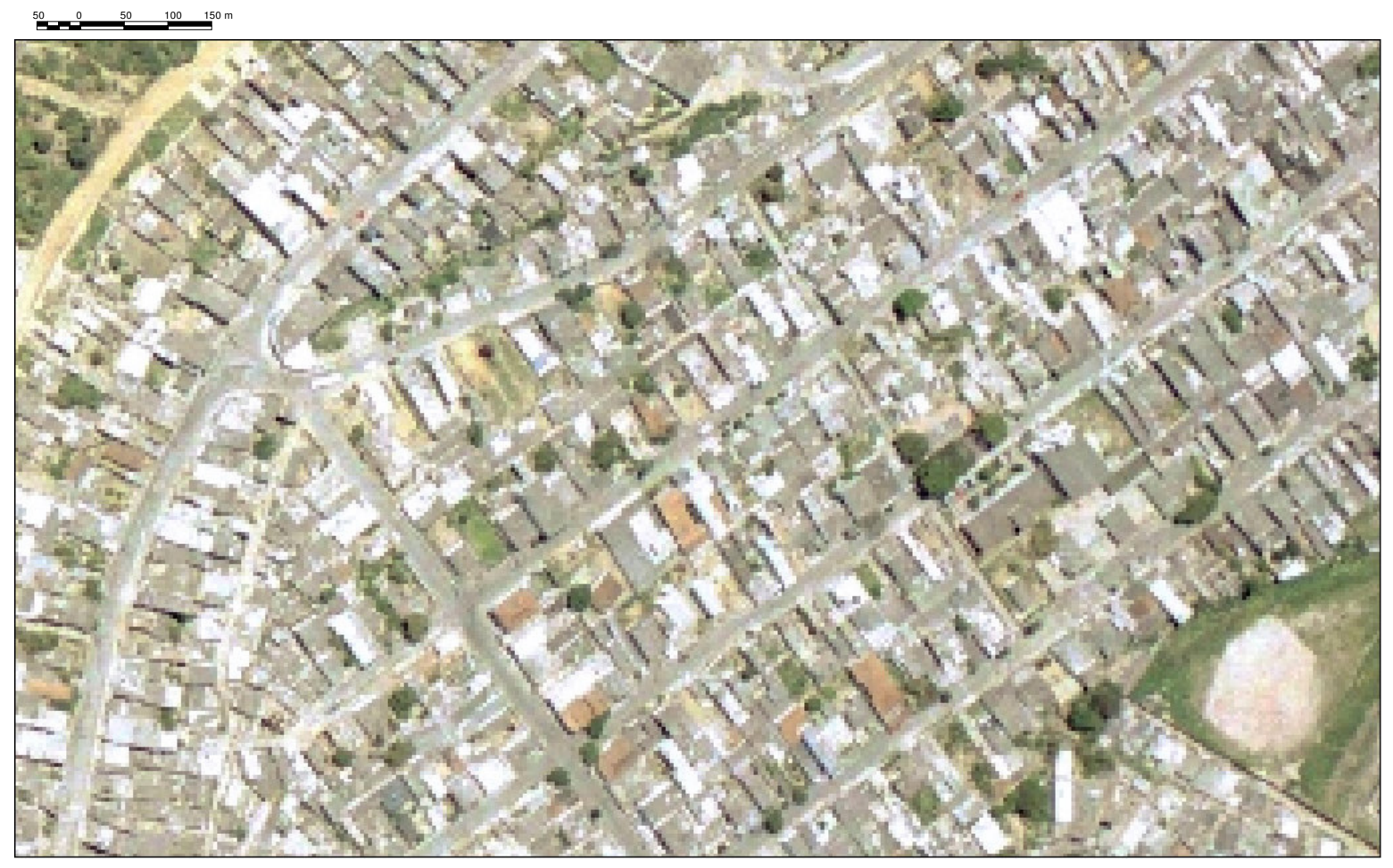

Figura 9 - foto aérea

\subsection{Chave de interpretacão das áreas homogêneas urbanas}

"Uma chave de interpretação é definida pela interação dos vários elementos que levam a interpretação de um dado fato presente na imagem em análise." (EMPLASA, 1979).

A primeira analise foi em busca de áreas que podiam ser consideradas homogêneas, sem defini-las ainda. Para realizarmos esse processo a orotofotocarta foi importada no programa de SIG Mapinfo onde foi analisada e foram desenvolvidos critérios para a criação da chave de interpretação.

A seleção de homogeneidade na orotofotocarta analisada em escala 1:5 000, leventamos os diferentes tipos de uso residencial, associados ao padrão construtivo, que por sua vez é associado à classe de renda do morador da área.

Assim, abaixo temos os principais elementos da chave de interpretação: 
- Densidade de casas - onde vemos a quantidade de casas em um determinado espaço.

- Qualidade da construção - por a foto ter um nível de detalhamento alto, podemos observar o tipo de construção.

- Visível pelo tipo de cobertura, cimento, lajes ou cerâmica.

- Tamanho ocupado - cada construção ocupa um tamanho no lote, apresentando nenhuma área livre, pouca área livre ou muita área livre intralote.

- Padrão, ordenação e homogeneidade das construções - tipo de cobertura.

- Recuo - distancia intralotes e entre o lote e o arruamento.

- Sistema de arruamento do lote - traçado, tamanho e tipo de viário.

- Mata no lote - podemos observar em algumas áreas uma maior ou menor existência de mata nos lotes ocupados.

- Localização - áreas que se localizam mais próximas das áreas da represa.

- Mata - nativa e reflorestada.

- Áreas comerciais de grande porte - tamanho do lote (superior ao residencial) e cobertura de cimento.

Tentamos padronizar essa chave com relação a realizada para as outras 3 cartas de 1962, 1974 e 1994. A grande diferença da chave de interpretação de 2001 é o uso urbano que está mais detalhado.

Com todos esses fatores apontados na analise, foi possível elaborar um mapa vetorial com polígonos que selecionam as qualidades acima citadas. Por fim foi possível classificá-las e obter a chave abaixo:

\subsubsection{Residencial de alto Padrão}

a) alta densidade 
Todos os usos de alto padrão são de alvenaria (telhados alaranjados), as áreas das casas são grandes, em média $400 \mathrm{~m}^{2}$ e são dispersos uma em relação a outra, com áreas verdes intralotes, mas ao contrário do baixo padrão, isso ocorre pelo aproveitamento da área verde e de grande recuo com relação às ruas. A ocupação é feita de um domicílio por lote, muitas vezes com construções secundárias (como piscinas) e com grande recuo com relação à rua.

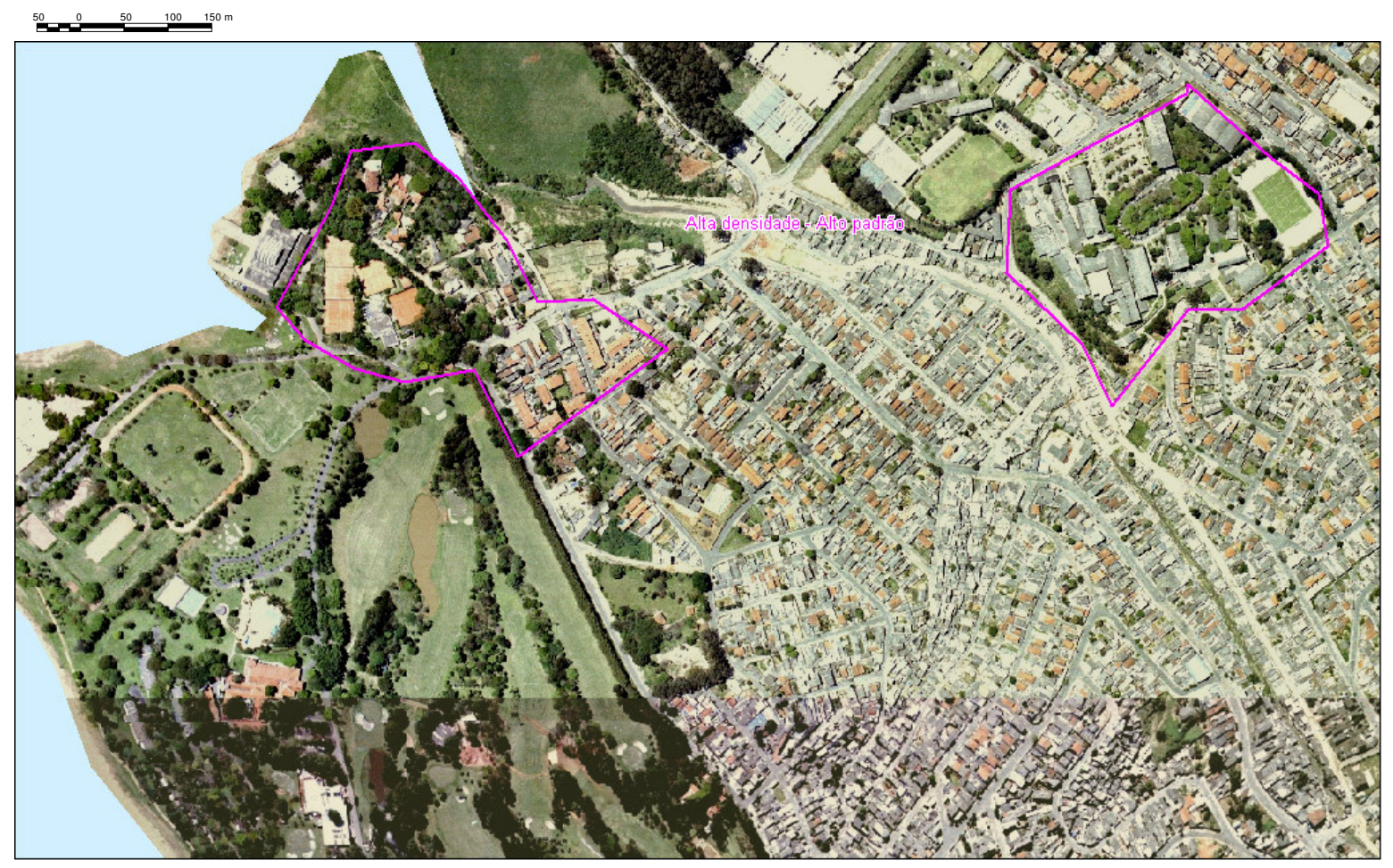

Figura 10 - Residencial de Alto padrão

b) baixa densidade

Os usos de alto padrão seguem o modelo do uso de alto padrão das áreas de maior densidade. Porém existem muito mais áreas verdes intralote nas áreas de baixa densidade que nas de alta. As casas apresentam recuo da rua maior, e a área ocupada (pela da construção) com relação ao lote é maior, com construções secundárias (como piscinas, quadras etc.), como mostra a figura 11. 


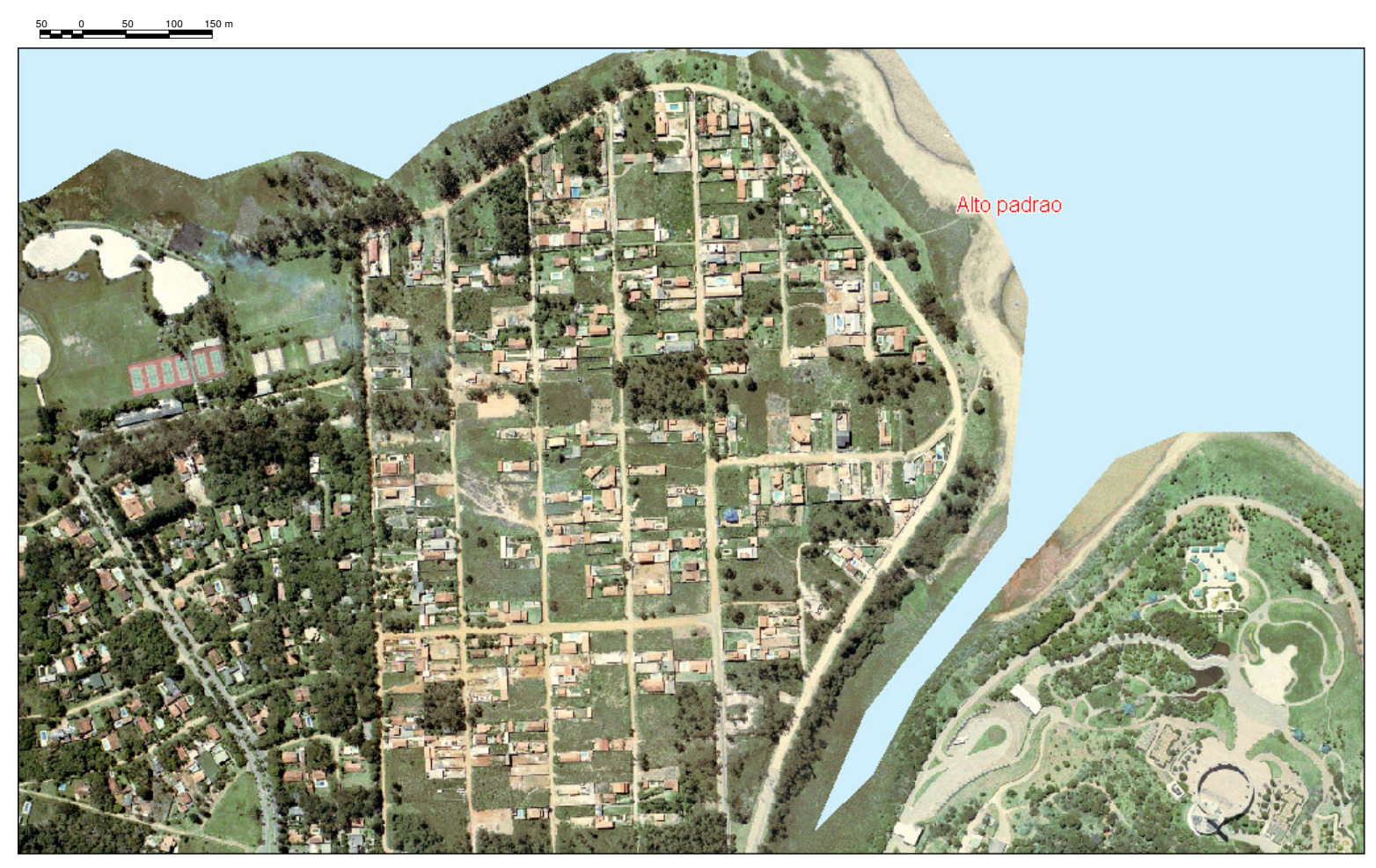

Figura 11 - Alto padrão em baixa densidade

\subsubsection{Residencial de médio padrão}

a) alta densidade

Ocupações de médio padrão (quadra em vermelho) apresentam uma disposição ordenada nos lotes com uma ocupação que segue paralelamente ao arrumento, com telhados maiores $100 \mathrm{~m}^{2}$. Telhado de cerâmica (cor alaranjada) com uma textura uniforme, mostrando casas de um mesmo tipo de construção, a padronização dos lotes. Esses são quase totalmente construídos, Porém com pouco espaço intralote, como mostra figura 13.

b) baixa densidade

O uso de médio padrão em baixa densidade segue o modelo do médio padrão em alta densidade, onde temos uma ordenação maior nos lotes e uma padronização da ocupação dos mesmos sendo de alvenaria e com coberturas de cerâmica. $O$ que difere é que por ser uma região de baixa densidade, não temos uma 
seqüência dessas casas, e sim loteamentos isolados próximos à vegetação, sendo assim áreas em expansão urbana, como mostra a figura 12.

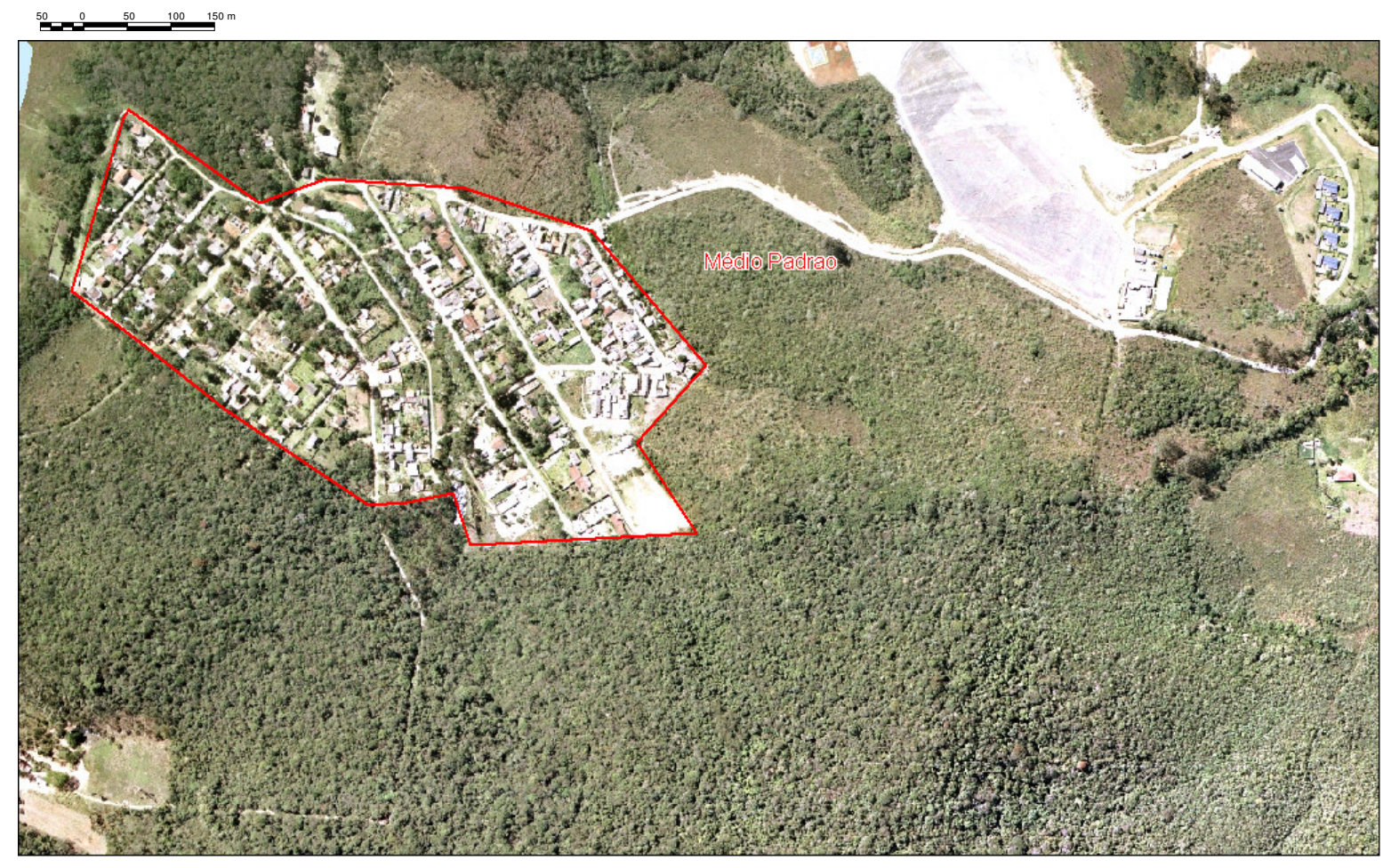

Figura 12 - Médio padrão em baixa densidade

\subsubsection{Residencial de baixo padrão}

a) alta densidade

Podemos distinguir o baixo padrão do médio pela falta de ordenação das construções, não segue mais paralelamente ao arruamento, ficando dispersos nos lotes, há pouco ou nenhum espaço intralote e pouco recuo com relação a rua. Porém, as ocupações apresentam muitas vezes coberturas de cerâmica e casas de tamanho que variam de 30 a $70 \mathrm{~m}^{2}$.

$\mathrm{Na}$ figura 13, podemos observar essas diferenças. Em azul temos uma quadra que apresenta baixo padrão em alvenaria, podemos observar facilmente a distribuição não planejada, com relação a área em vermelho onde há uma ordenação. 


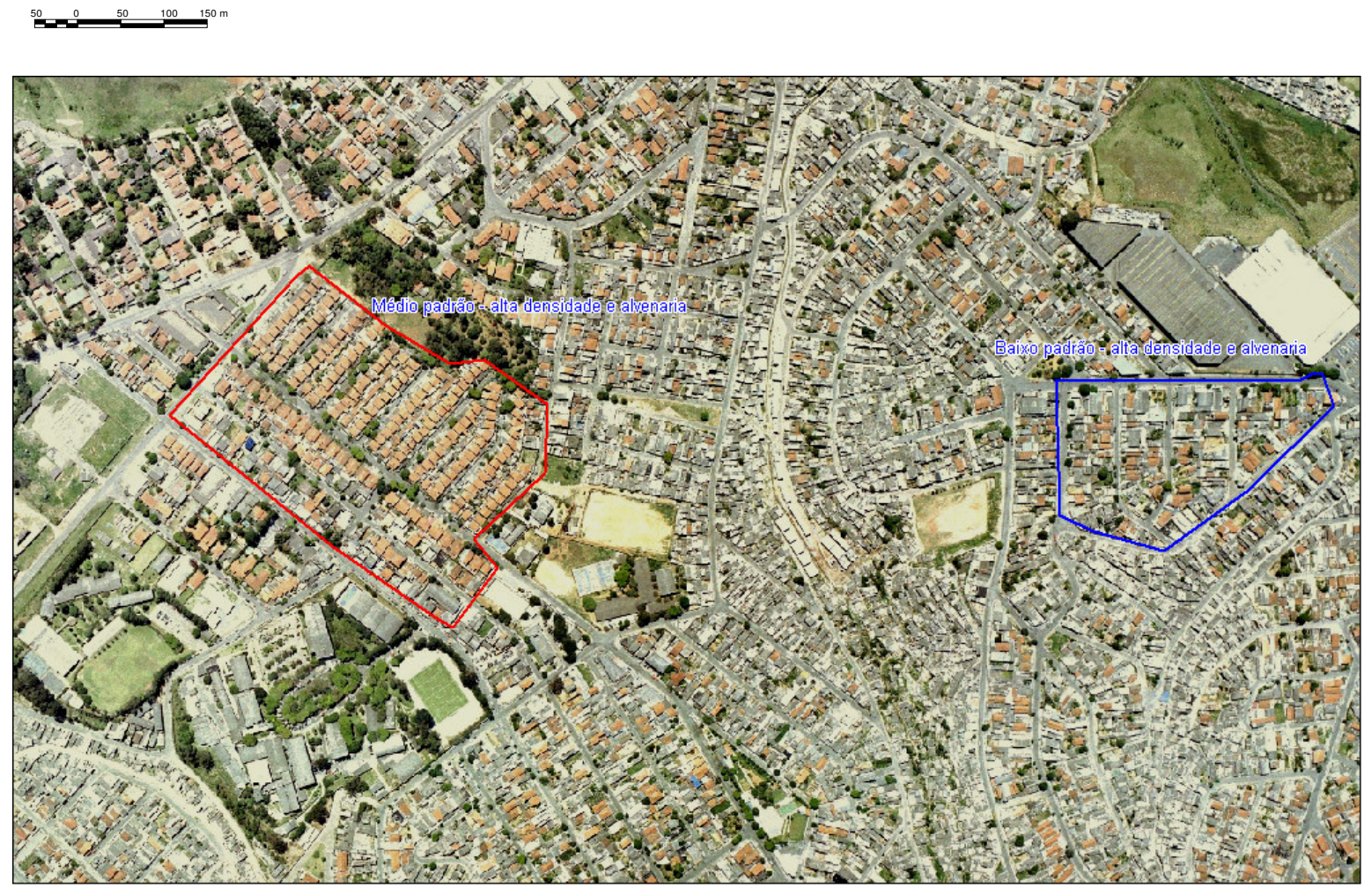

\section{Figura 13 - Médio padrão e baixo padrão}

b) baixa densidade

As construções não seguem um padrão único de ocupação, podendo ser de alvenaria quanto de concreto, o tamanho das construções também variam de 30 a $70 \mathrm{~m}^{2}$. As ocupações não são distribuídas uniformemente, apresentando mais espaço intralote assim como recuo à rua, diferentemente do uso de alta densidade, como mostra a figura 14. 


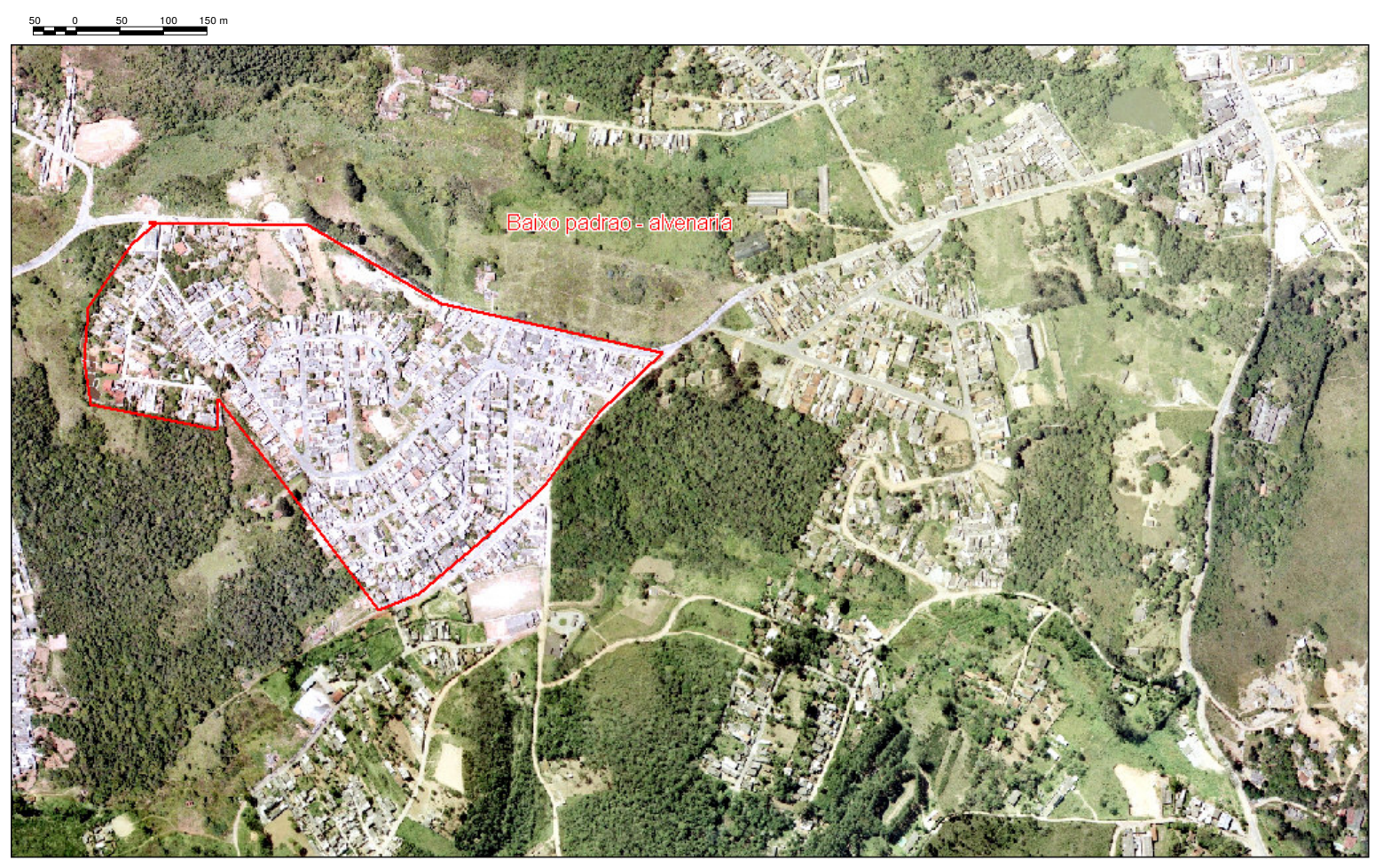

Figura 14 - Baixo padrão residencial em baixa densidade

\subsubsection{Residencial favelas}

a) alta densidade

São construções em sua maior parte com coberturas de cimento ou de lajes. Existe pouco ou nenhum ordenamento das construções com relação ao arruamento e quase nenhum espaço intralote.

Apresenta uma textura acentuada, onde podemos observar que não há uma padronização na construção das casas (cada uma foi feita a um momento e de uma forma), e grande densidade (muitas vezes mais de uma construção por lote) que impossibilita a identificação das áreas das ocupações, como mostra a figura 15. 


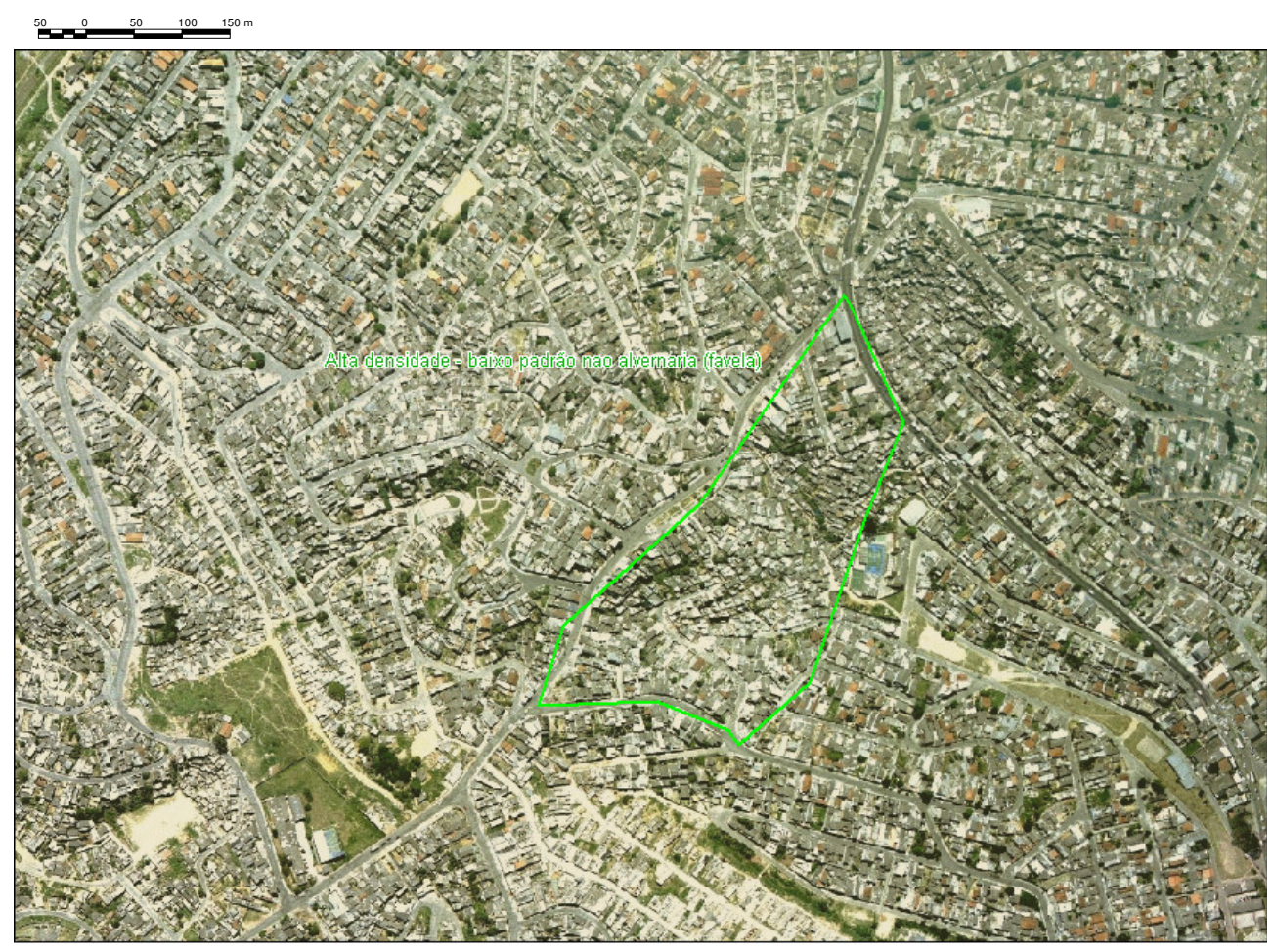

Figura 15 - Uso residencial favela - Alta densidade

b) baixa densidade

O tipo de construção segue o modelo de uso residencial de favela de alta densidade, inexistência de ordenação dos lotes e da ocupação; pouco espaço intralote e esse não ocupado por vegetação. Existe um pouco mais de ordenação com relação a construção do lote, possibilitando ate mesmo um espaço intralote, que não vemos no uso de alta densidade.

A figura abaixo (figura 16) apresenta a oeste lotes densos, e a leste lotes menos densos, porém a estrutura e a textura se mantêm igual nos dois espaços, sendo assim um mesmo tipo de ocupação. 


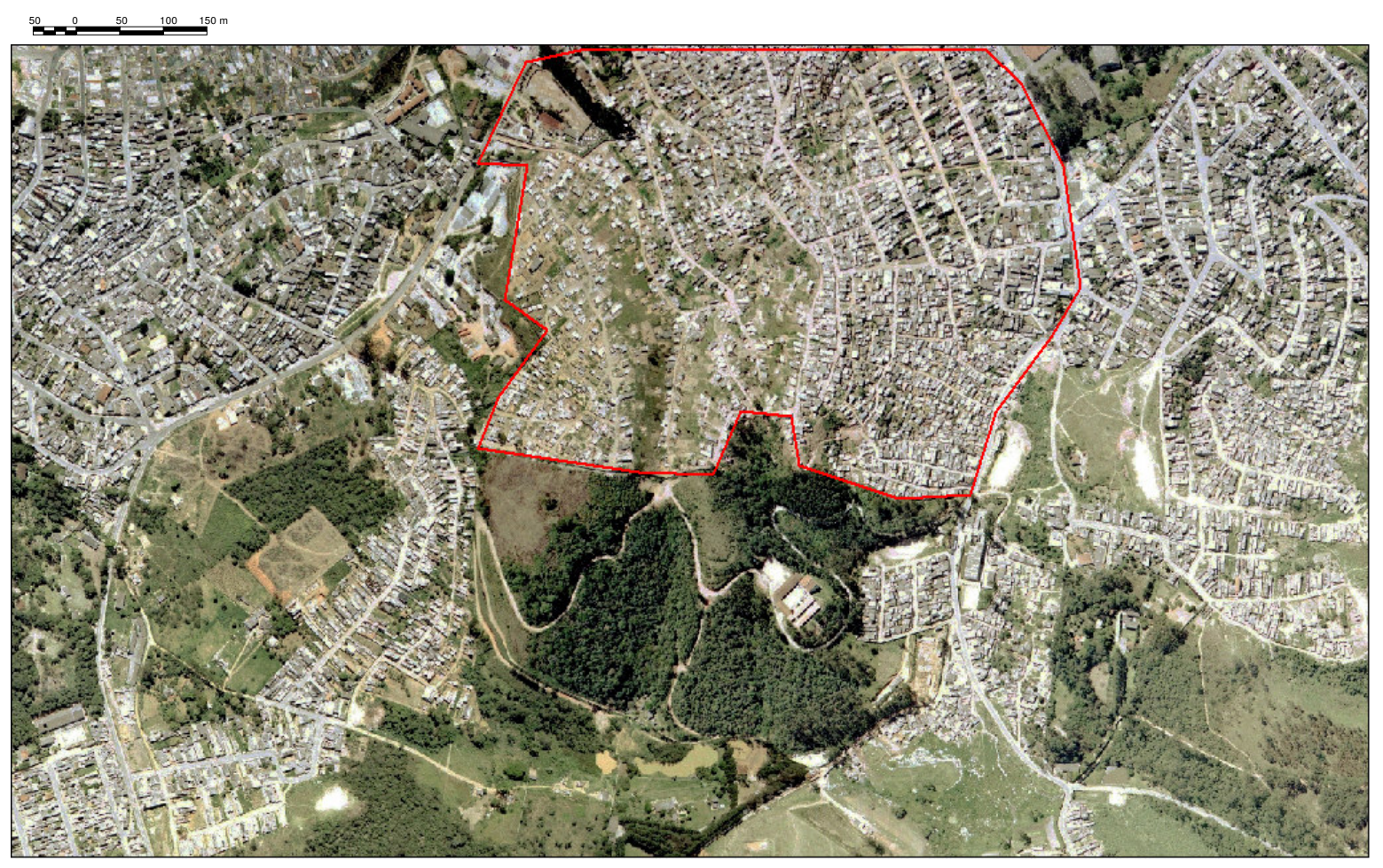

Figura 16 - Uso residencial favela - baixa densidade

\subsubsection{Uso não residencial}

São usos que se apresentam com grandes áreas construídas em sua maioria em cimento, alem de estar próximo a grandes vias de transporte. Não é classificado em alta ou baixa densidade por ocupar sempre uma grande área, e ser uma ocupação não residencial isolada, como mostra a figura 17.

Somente pela foto não há possibilidade de sabermos se é um centro de distribuição, uma indústria ou até mesmo um grande varejo, como um hipermercado.

Pelos dados de estabelecimentos comerciais e de serviços é possível distinguir o uso comercial ficando indistinguível o uso de distribuição ou indústrias. 


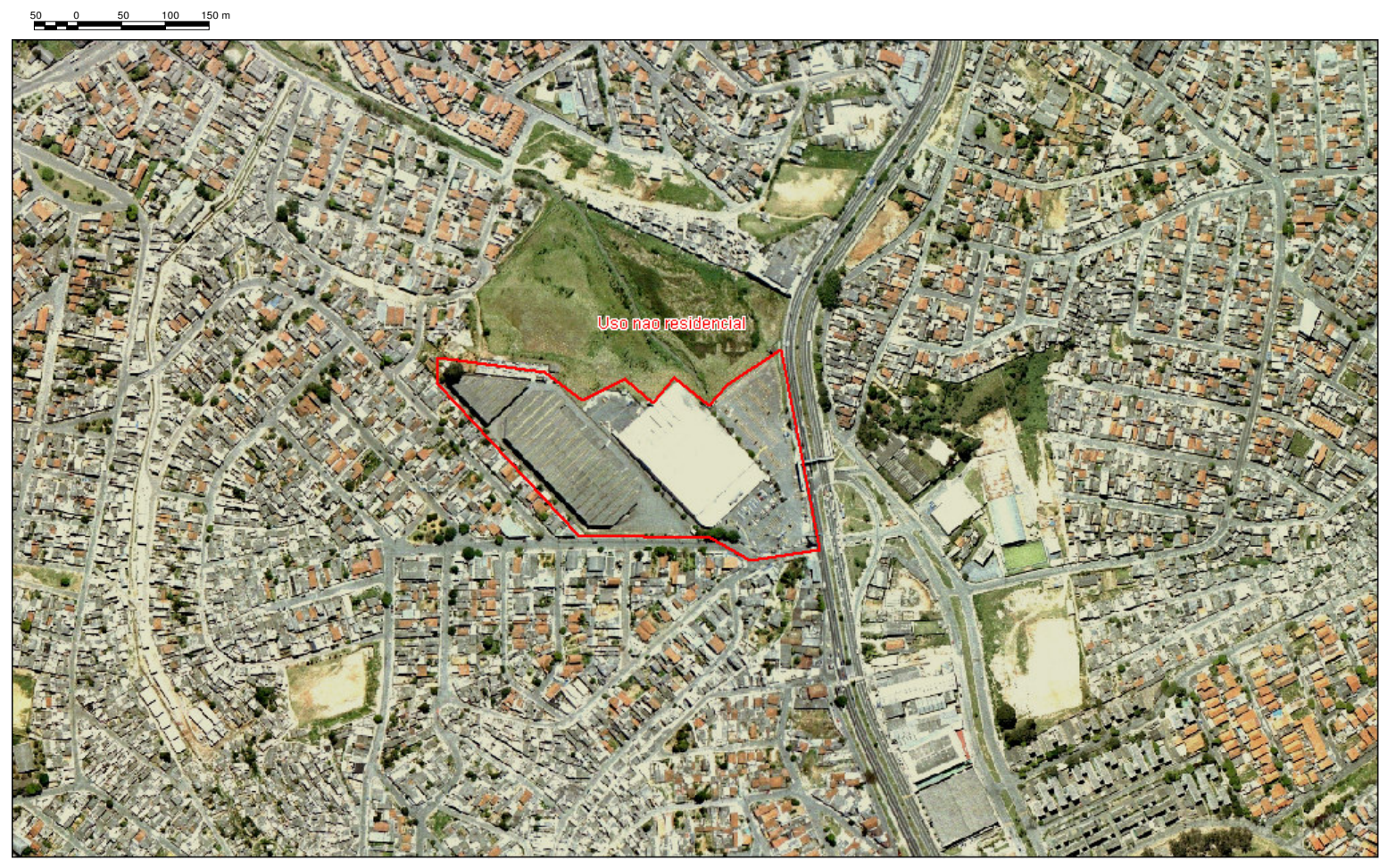

Figura 17 - Uso não residencial de grande porte, próximo a Avenida Teotônio Vilela

\section{$\underline{\text { 5.1.6 Mata nativa }}$}

A mata nativa apresenta-se com coloração verde escura, e com textura de bastante rugosidade e sombreamento irregular. Essa rugosidade nos permite diferenciá-la do reflorestamento. Já que cada árvore nasceu e cresceu em momentos diferentes, há um aumento da impressão de rugosidade, exatamente por cada árvore ter um tamanho diferente, como mostra a figura abaixo (18). 


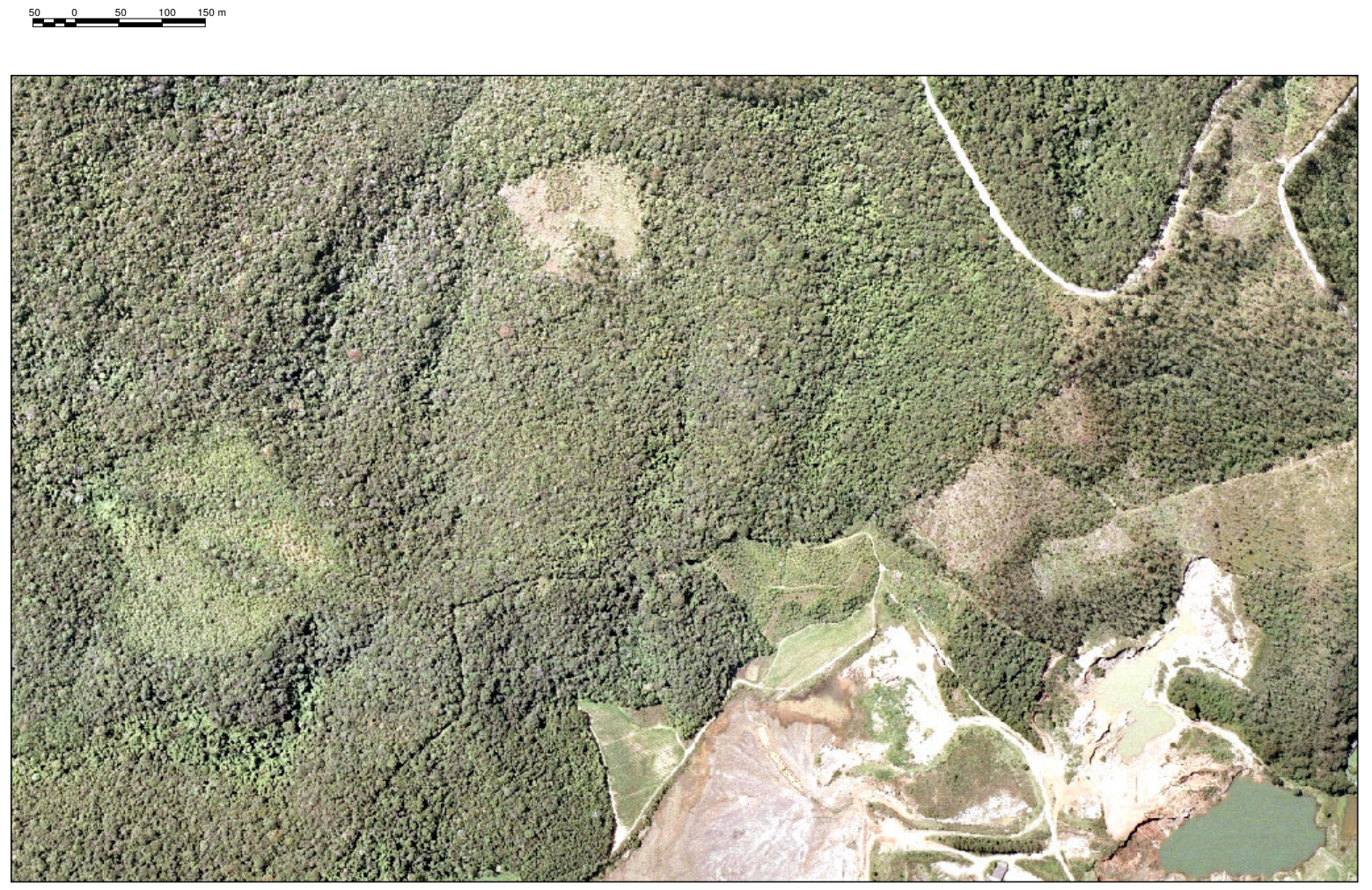

Figura 18 - Mata Nativa

\subsubsection{Reflorestamento}

Apresenta coloração verde mais clara com relação à mata nativa. Apresenta a textura lisa e o sombreamento é regular, conforme a figura 19.

O reflorestamento é uma área que foi replantada toda em um mesmo momento, assim a altura das arvores é semelhante, tendo na foto uma impressão de área mais lisa que a mata nativa. 


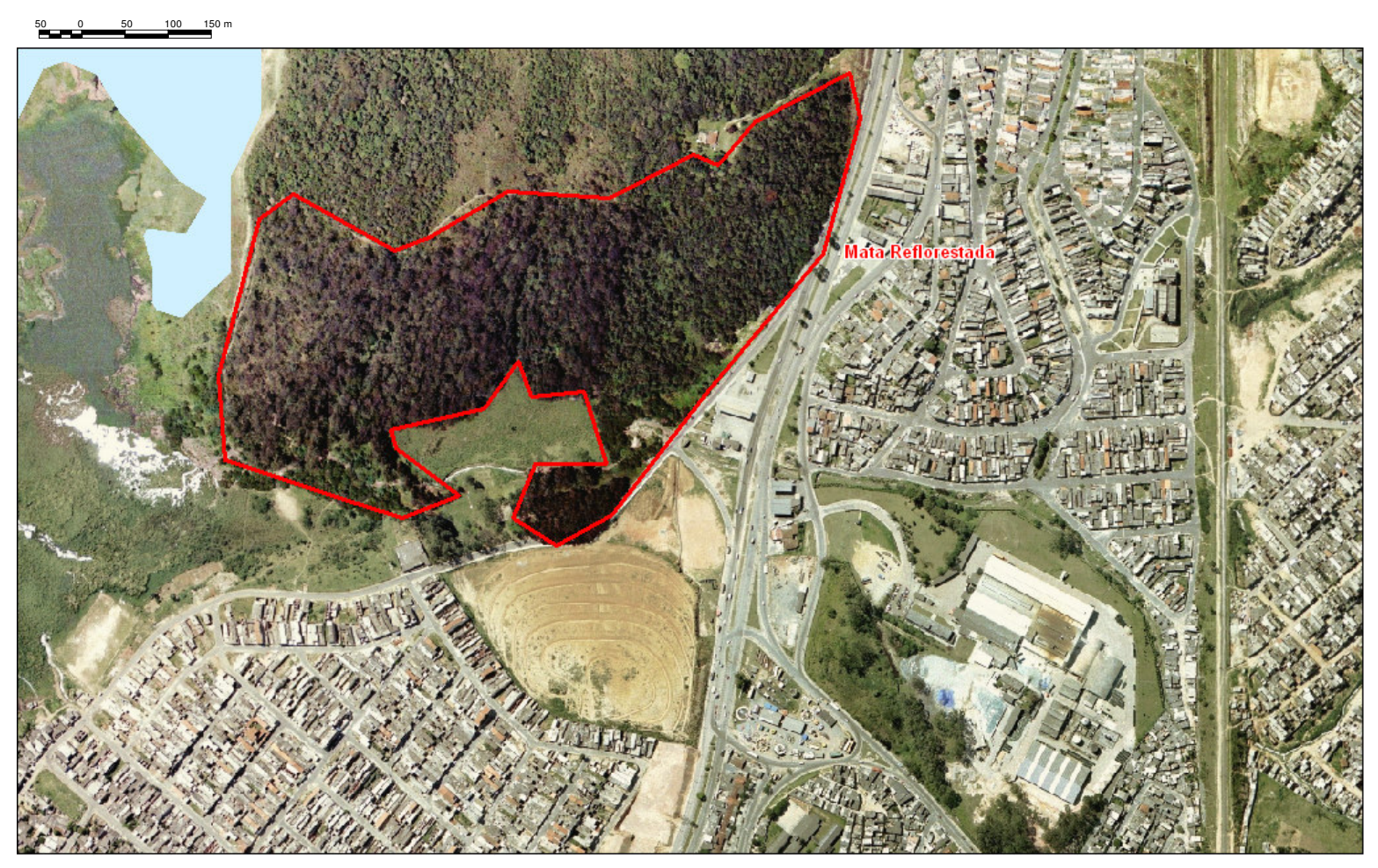

Figura 19 - Reflorestamento

Podemos observar, tanto na mata nativa, quanto no reflorestamento, que sempre há presença urbana próxima a elas. Isso por a área de estudo tratar-se de uma região quase totalmente urbanizada.

Nas regiões sul e oeste da represa, que são regiões de menor densidade, temos mais áreas de mata (nativa ou reflorestada), porem sempre próximo a elas temos áreas urbanas, mostrando bem o caráter urbano da área. 


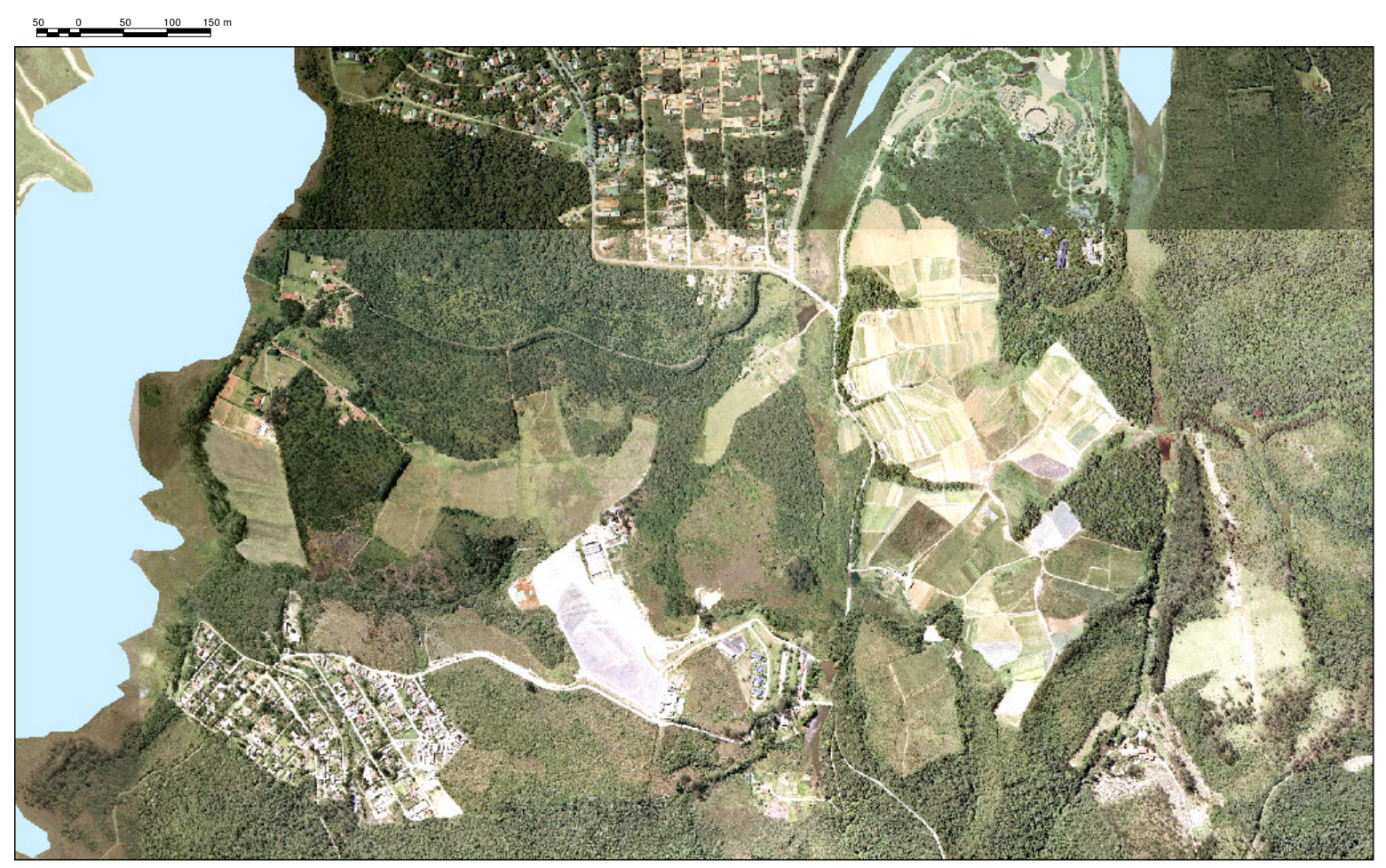

Figura 20 - Mata próxima a área urbana

\subsubsection{Cultivo}

Existem algumas áreas de cultivo, que podem ser percebidas pela coloração branca ou de tons pasteis (dependendo do tipo de cultivo), altura baixa e sombreamento regular, a forma é geométrica com áreas grande $300 \mathrm{~m}^{2}$ em média, conforme figura abaixo (21). 


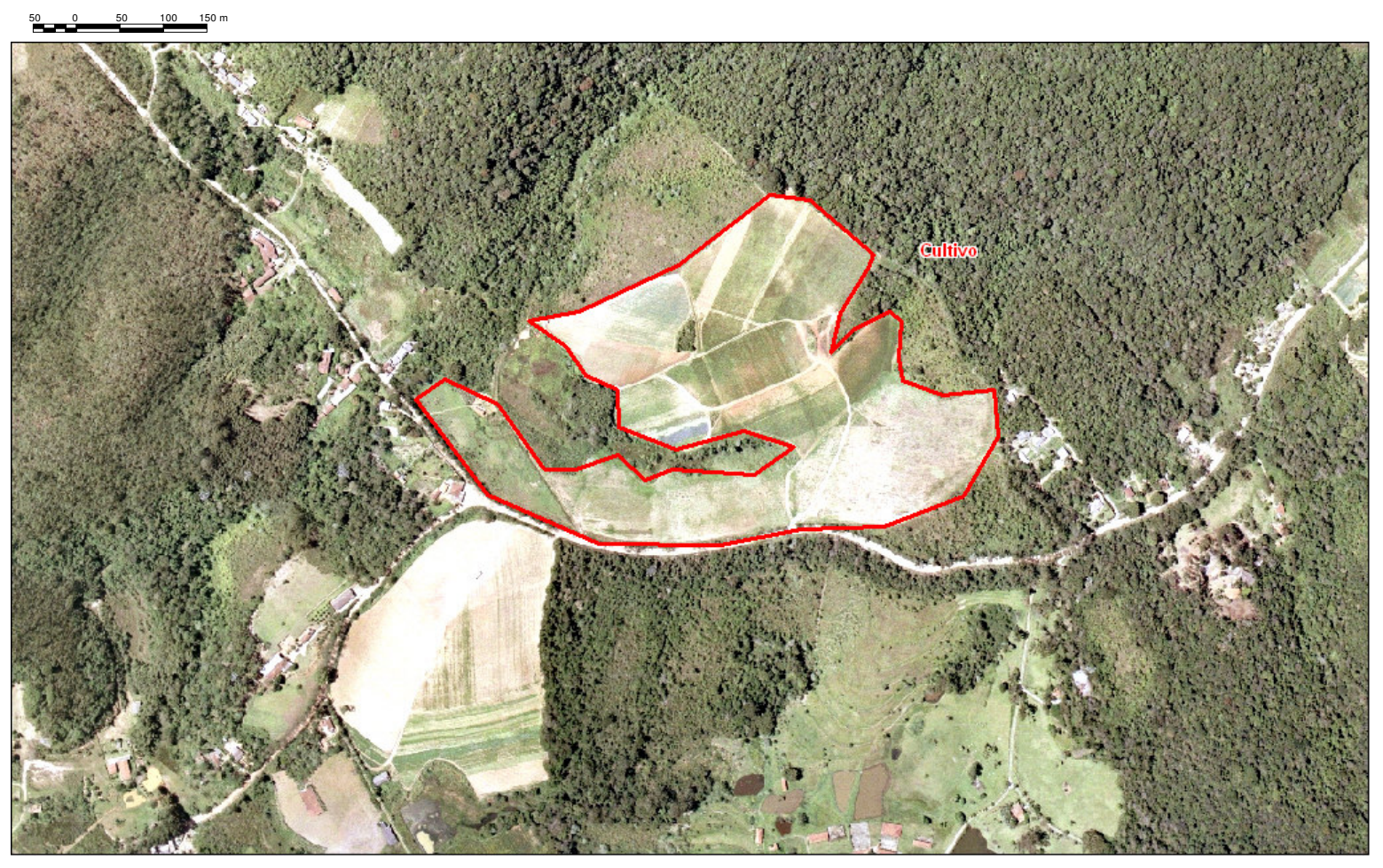

Figura 21 - Cultivo

\section{$\underline{\text { 5.1.9 Mineração }}$}

Desde o começo de nossa analise (1962), identificamos uma área de mineração bem próxima à represa, e podemos observá-lo na foto aérea. Aparece como uma área branca, diferente do cultivo, pois são claramente vistos pontos de erosão, e deposito de resíduos em planícies aluviais.

Os pontos de erosão são vistos como áreas mais escuras, e com rugosidades. 0 deposito de resíduo na água é visto como uma parte branca reluzente, como mostra a figura 22. 


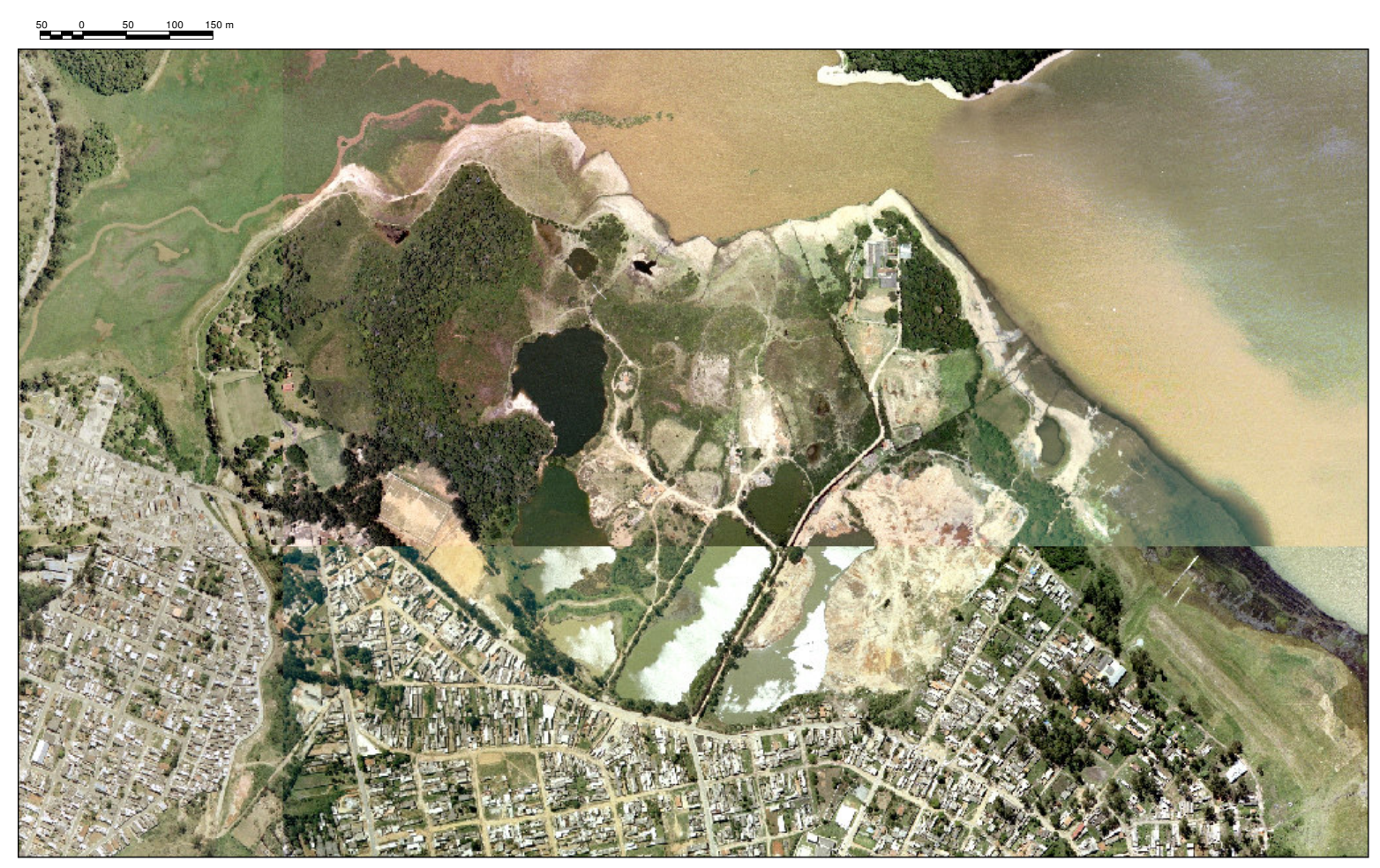

Figura 22 - Mineração

Podemos com essa chave apresentar os vários tipos de ocupação do espaço. Observando que na região de estudo como um todo, as áreas sul e oeste à represa possuem uma densidade de construções mais baixa que a área leste.

Outra analise realizada foram os tipos de construções: alto, médio e baixo padrão, e no caso do baixo padrão, temos as autoconstruções e as favelas. A ocupação dos terrenos também foi levada em consideração - taxa de ocupação do lote, ocupação organizada entre outros.

Uma das classificações da chave de interpretação seriam os usos comerciais e de serviços, como escolas, shoppings e supermercados. Por se tratar de uma área muito densa, principalmente ao leste da represa, não foi possível essa interpretação, pois as construções estão muito próximas, além de muitas delas não terem uma dinâmica única que possibilite sua diferenciação das demais residências, como mostra a seqüência de ilustrações 23 e 24 . 
Esses pontos de serviços fazem com que se mantenham ou até se atraia mais pessoas uma área. Já que em uma metrópole como São Paulo, os bairros possuem sua própria centralidade com comércios e serviços próximos a população local.

Para termos esse dado, tivemos acesso ao banco de dados de estabelecimentos comerciais e se serviços junto à empresa Cognatis, sócia da Multispectral. Esse banco de dados nos possibilita a visualização dos pontos de comércio e serviços que não são possíveis de distinguir pelas fotografias, como mostra figura $23 \mathrm{em}$ conjunto com a 24 (escala 1:10 000). 


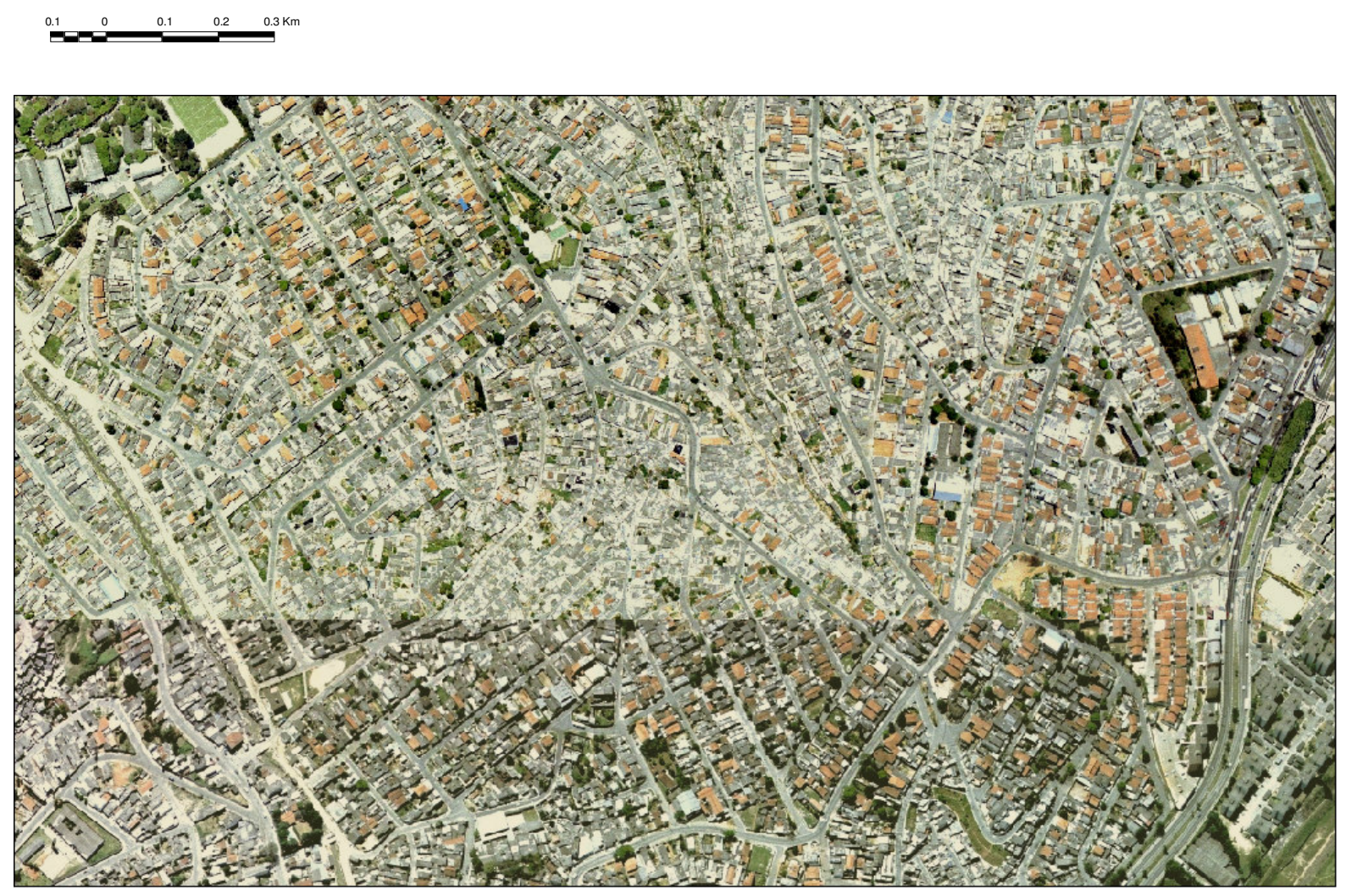

Figura 23 - Parte de foto sem estabelecimentos 


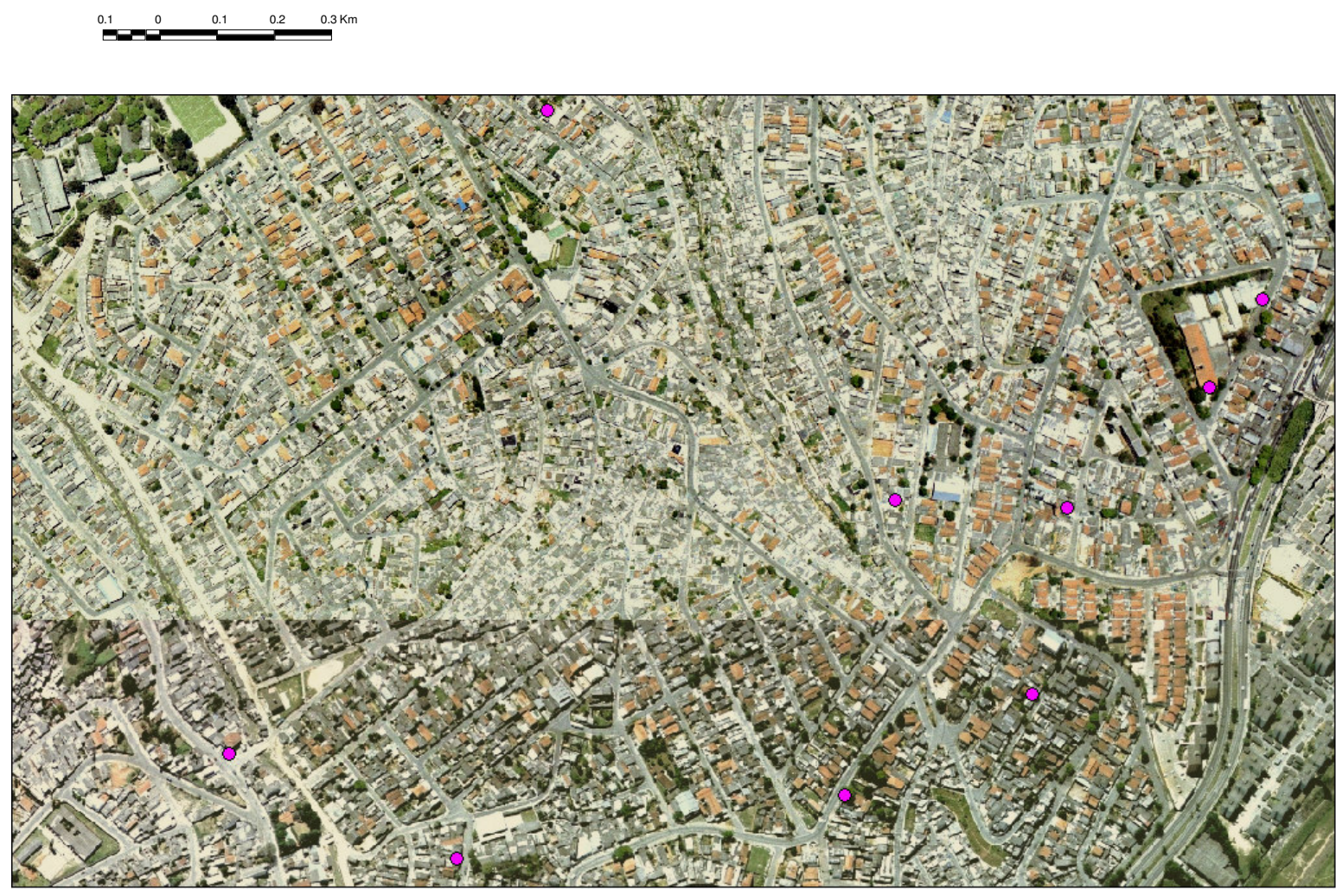

Figura 24 - parte de foto com estabelecimentos

$\mathrm{Na}$ figura 24 os pontos rosa são escolas. Podemos observar que algumas escolas não seriam vistas somente pela interpretação das fotografias, de modo que adotamos essa tabela de estabelecimentos para entendermos a dinâmica comercial da área, junto com a expansão urbana. 


\begin{tabular}{|l|r|}
\hline TIPO DE POLO & QUANTIDADE \\
\hline ACOUGUES & 1 \\
\hline AGENCIAS BANCARIAS & 9 \\
\hline BARES & 7 \\
\hline CABELEIREIROS & 10 \\
\hline CAFES & 1 \\
\hline CAIXAS ELETRONICOS & 8 \\
\hline CLUBES & 5 \\
\hline DOCERIAS & 2 \\
\hline ESCOLAS & 114 \\
\hline ESCOLAS DE IDIOMAS & 2 \\
\hline ESCOLAS DE INFORMATICA & 3 \\
\hline FINANCEIRAS & 2 \\
\hline GRANDES FRANQUIAS & 8 \\
\hline GRANDES VAREJOS & 4 \\
\hline HIPER/SUPERMERCADOS & 21 \\
\hline LAVANDERIAS & 2 \\
\hline LOJAS DE PISOS, AZULEJOS E AFINS & 1 \\
\hline OFICINAS MECANICAS & 1 \\
\hline PAPELARIAS & 1 \\
\hline PERFUMARIAS & 13 \\
\hline PNEUMATICOS & 3 \\
\hline RESTAURANTES & 8 \\
\hline
\end{tabular}

Tabela 1 - Estabelecimentos comerciais e de serviços

Podemos observar pela tabela acima, que nem todos os estabelecimentos são contemplados nesse banco de dados. Isso porque a Cognatis faz um levantamento deles via internet, tanto em sites dos estabelecimentos (como de bancos, grandes supermercados etc) como em sites de listas de consumo como a lista OESP (Organização Estado de São Paulo) e associações de mercado como associação de supermercados, de fast food entre outros.

Assim, não são englobados os mercados informais, estabelecimentos que não tem registro de funcionamento ou que não fazem parte desses acima citados. Podemos então considerar o banco de estabelecimentos um banco amostral de onde existem estabelecimentos e seus tipos.

\subsection{Interpretacão da foto e criacão da carta de áreas homogêneas urbanas}

Após a elaboração da ortofotocarta e da chave de interpretação, foi realizada a fotointerpretação, que constitui da analise das fotografias pelo observador. 
Previamente foi realizada uma visita a campo para que tivéssemos uma visão mais detalhada da área em estudo e que pudesse reconhecer na foto algumas paisagens que verificou em campo, visando uma melhor qualidade real na interpretação da foto.

Feito esse processo, a foto foi interpretada faixa a faixa (pois o programa e 0 computador não suportam a abertura do mosaico inteiro, por se tratarem de arquivos muito grandes), a cada paisagem encontrada foi desenhado um polígono a sua volta e complementada a tabela com a informação do tipo que é essa paisagem.

Nosso resultado são 638 áreas, que correspondem aos 16 tipos de uso que podemos ter na área. Ressaltando que o uso de vegetação não era o foco da interpretação.

\subsection{Interpolacão dos dados da carta com os dados do censo}

Depois de elaborada a carta de áreas homogêneas, o próximo passo foi agregar informações sócio demográficas a mesma. No ano de 2000 o IBGE realizou um censo do Brasil Inteiro, disponibilizando os dados os dados por áreas chamadas de setor censitário as quais são agregadas informações. Pudemos, via programação, fazer a interpolação dessas duas tabelas. Assim para cada um dos 638 polígonos temos a quantidade de casas, pessoas, renda entre outros dados do censo.

Como o mapa de setores censitários é um mapa realizado para melhor desempenho do censor, tendo em média 200 domicílios, ele não obedece a uma lógica das áreas urbanas, diferente da carta que elaboramos que apresenta essa homogeneidade.

As áreas homogêneas não acompanham as áreas do censo, para podermos colocar os dados do censo em nossas áreas fazemos a interpolação dos mesmos para que a área homogênea seja uma soma dos dados das áreas do censo que são contidos nela. E os setores que não são contidos inteiramente em uma área, é 
calculada a soma proporcional por área desses dados, distribuindo assim o valor proporcional para a área que o contem.

A maior parte das vezes uma área homogênea contem mais de um setor censitário, Porém os limites das mesmas nem sempre se encontravam, de modo que se fizéssemos uma soma simples estaríamos perdendo dados sócio demográficos de uma área para outra. Isso ocorreria uma vez que o programa entende que uma área está dentro da outra se o centróide (ponto central do polígono) estiver contido nessa área.

Para evitar distorções da soma dos dados, foi utilizada uma programação junto com uma ferramenta mapinfo que permite a soma proporcional dos dados de duas tabelas geográficas que se cruzam. Desse modo, quando uma área homogênea contém mais de um setor, é feita a soma dos dados que estão contidos. Assim, se o setor está contido em somente uma parte é feita uma soma proporcional sobre essa área.

Essa função nos permite uma avaliação mais precisa do que ocorre na área em termos de dados sócio-demográficos, levando-se em conta que os dados representam a realidade tanto quanto a foto que foi interpretada.

\subsection{Carta de áreas homogêneas urbanas}

Como resultado temos, além do mapa temático das áreas homogêneas urbanas, mapas de informação do censo, como quantidade populacional e renda, entre outros resultados que também são apresentados por meio de tabelas e gráficos que nos mostram a qualidade de uso dessa área. 


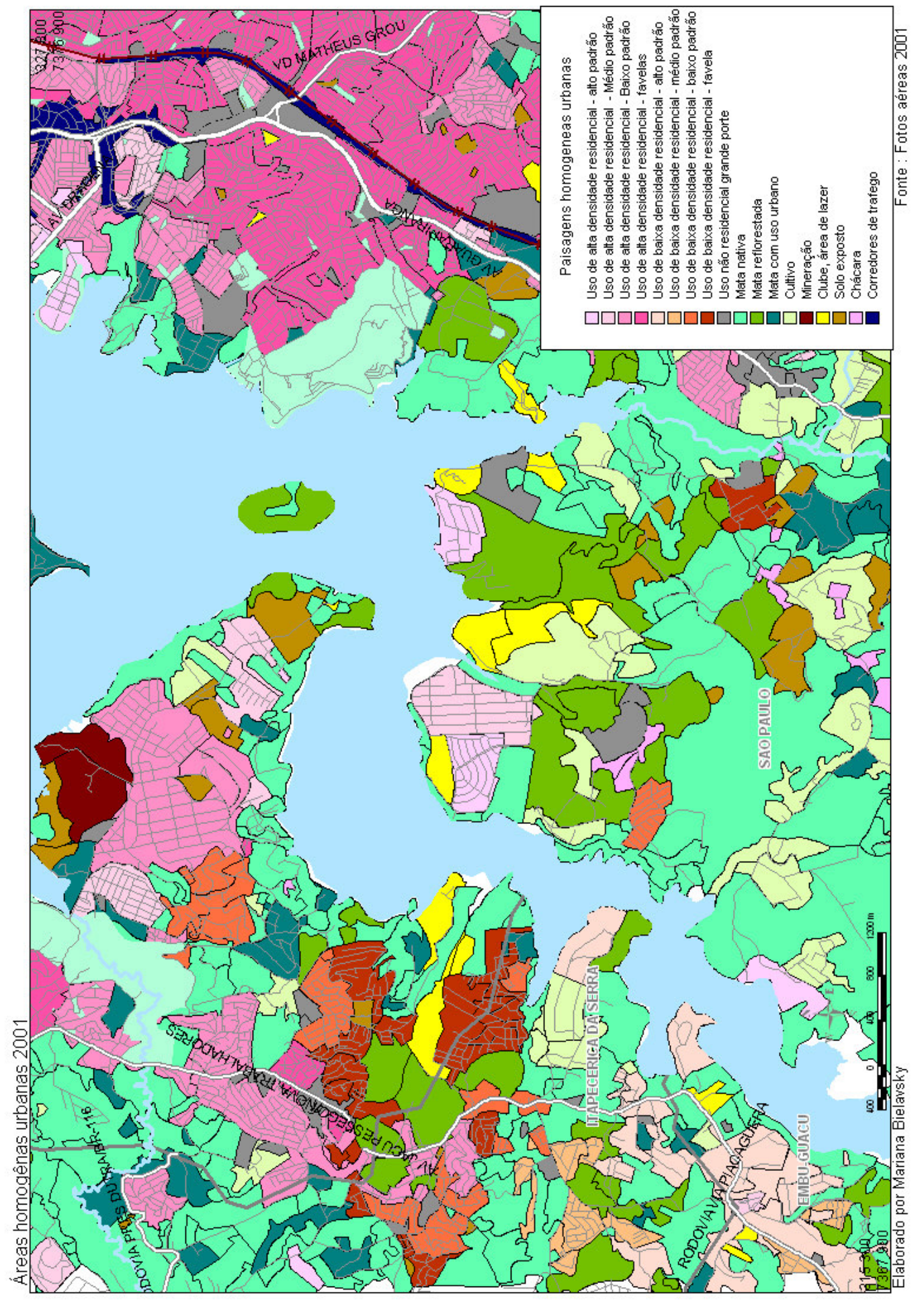

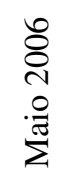

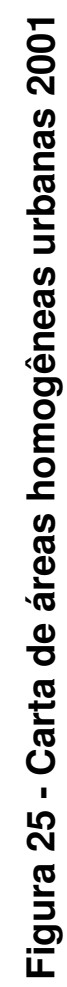

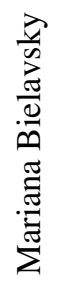


Podemos observar na figura 25, que a área em estudo tem uma grande ocupação urbana, predominam os tons de rosa e vermelho (e seus degradés) que representam os vários tipos de construção, desde alto padrão até favelas.

A leste do reservatório, onde a densidade de construções é alta podemos observar uma mancha em tons de rosa, que mostra uma grande quantidade de construções residenciais principalmente de baixo padrão. Não é toda a área que é composta por residências de baixo padrão, existem alguns pontos de médio padrão e até de alto padrão bem próximos ao reservatório, relembrando o primeiro uso dessa região - lazer para as classes mais altas.

Podemos ainda observar na região leste, a presença de grandes avenidas e de linha de trem, que são de extrema importância para o transporte na região que facilita a residência de pessoas nessa região.

A oeste do reservatório temos um uso diferente com relação ao leste, Porém ainda intensamente urbano. Temos residências de médio padrão, e algumas áreas de construção residencial de baixo padrão. Além de apresentar um uso menos urbano (ainda que de baixo padrão), tendo vários polígonos que representam vegetação, há o destaque de uma concentração central de urbanização, e outra a noroeste bem próxima ao reservatório.

Distante do reservatório temos uma área que apresenta vários polígonos de usos de construções residenciais de baixo padrão junto à vegetação. São áreas que possuem poucas casas ocupando essa área junto com uma grande quantidade de vegetação. São moradias isoladas que podem ser de médio ou alto padrão, e muito raramente de baixo.

Ainda próximo à represa, temos a mineração de areia que existe nessa região desde 1962, ano de inicio do panorama dos últimos 40 anos. Podemos observar que essa mineração encontra-se bem próxima ao reservatório e de um dos rios que a alimentam, o que aumenta a possibilidade de poluição e assoreamento da mesma.

A sudoeste do reservatório temos ainda um uso residencial de alto e médio padrão de baixa densidade. Ainda havendo em seu entorno muita vegetação, 
principalmente de mata nativa; essa região corresponde aos municípios de Itapecerica da Serra e Embu-Guaçu.

A região sul, situada em São Paulo, apresenta de vegetação, tanto nativa quanto de reflorestamento. Nessa região há bastante cultivo e solo exposto, assim como uso residencial junto com vegetação. O que caracteriza a área de baixa densidade e com uso menos urbano que as demais áreas.

Por toda a extensão da área de estudo, temos usos não urbanos de grande porte, que podem ser distribuidoras, fabricas, até mesmo supermercados e outros. Pela fotografia não é possível identificar o tipo de uso, para usos comerciais podemos utilizar a tabela de pólos que terá seu resultado apresentado abaixo.

O que podemos observar nessa carta de áreas homogêneas urbanas para o ano de 2001, é que a urbanização da área realmente se intensificou nas regiões leste e oeste do reservatório. Mostrando o que já se havia notado nos anos anteriores, que o crescimento urbano da cidade se dava nessa direção.

A infra-estrutura urbana é um dos fatores que auxiliam e que trazem pessoas para morarem em regiões longe da cidade formal, pessoas que vêem nessa região uma alternativa de moradia, principalmente de usos residenciais de baixo padrão que são as pessoas que não encontraram seu lugar na formalidade. 


\subsubsection{Estabelecimentos comerciais e de servicos}

Para entendermos melhor a dinâmica da área em estudo, elaboramos um mapa que aponta os tipos de estabelecimentos comerciais da área em estudo. Os pontos mostram por tipo o comércio e serviços existentes na área.

Entre estes, encontram-se os tipos básicos de comercio para um morador não necessitar sair do bairro para resolver seus assuntos, que vão desde agências bancarias a lojas especificas como pneumáticos.

$\mathrm{Na}$ carta abaixo (figura 26) podemos observar que os estabelecimentos estão concentrados exatamente onde há mais pessoas vivendo, ou seja, o comercio se estabelece seguindo a lei da oferta e da procura, onde há mais fregueses. O que por sua vez, atrai ainda mais moradores para essa área, já que o mínimo de comercio é encontrado no local, apontando dessa forma para quem vai ali morar o conforto e a infra-estrutura básica para um consumidor que não necessariamente é um cidadão, pois pode viver as margens da cidade e ate da lei (de uso e proteção do solo).

O que vemos na carta abaixo, é que os estabelecimentos acompanham o vetor de crescimento nas áreas leste e oeste. Mostrando que realmente a mancha urbana está crescendo nessa direção. Essas duas áreas são que predominam a população, principalmente de baixa renda, como comércios e serviços que permitem que essa população continue morando ali, sendo suprida dessas necessidades. 


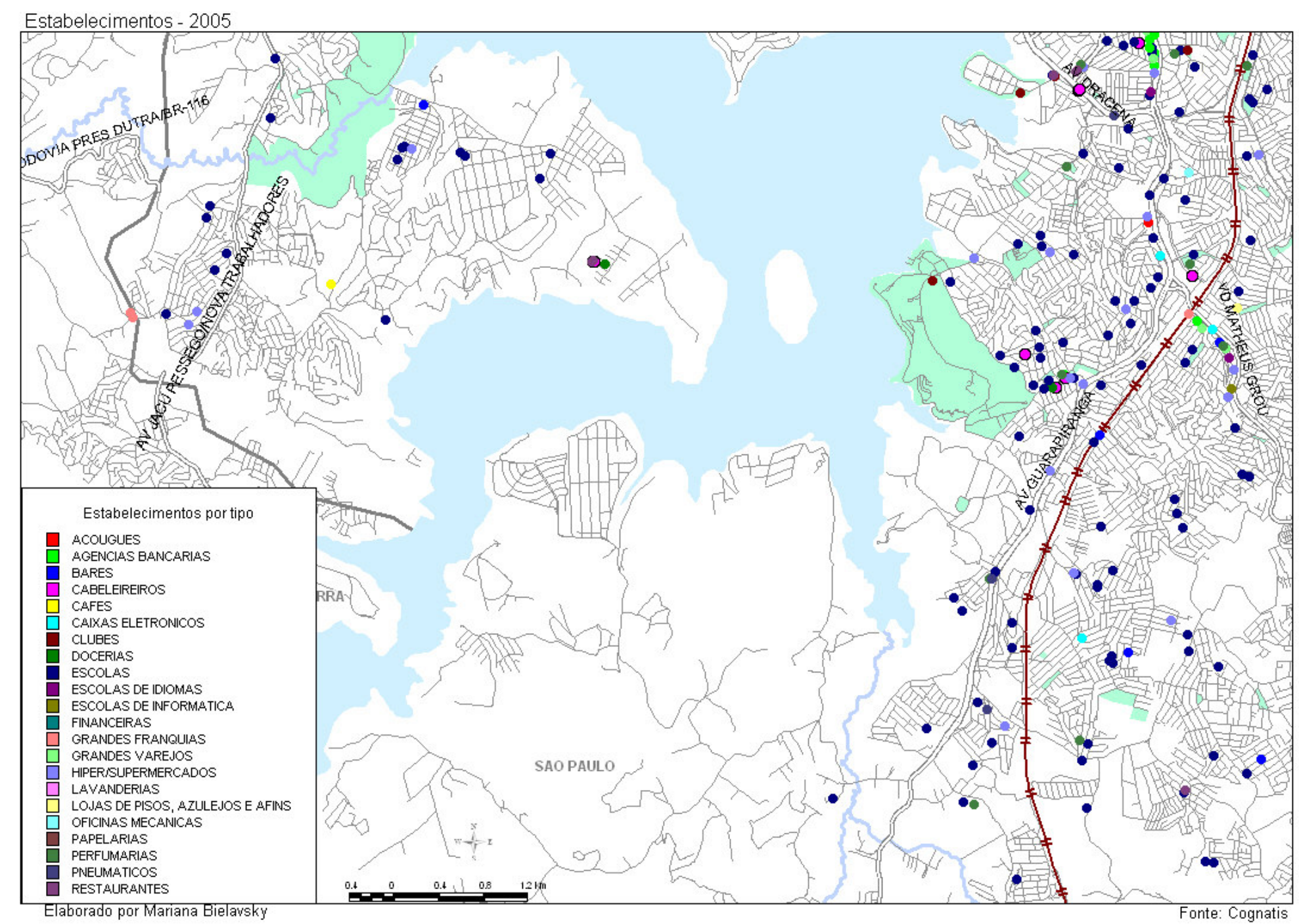

Figura 26 - Estabelecimentos comerciais e de serviços 


\section{$\underline{5.5 \text { Dados do censo } 2000}$}

A observação do crescimento da cidade dá-se não somente por onde são construídas as novas moradias no decorrer dos anos e nos serviços próximos, mas também pelo tipo de população e suas características sócio demográficas.

Assim, com os dados do IBGE para o ano de 2000 podemos observar algumas características da população residente na área em estudo.

Para esses primeiros mapas, foram escolhidas variáveis que representem a demografia da região que são: população (variável bruta), densidade populacional (pessoas/área) e renda média do responsável pela residência que foi dividido em classes para facilitar a divisão de renda das residências da área.

As informações do censo 2000 foram adicionadas via programação SIG nas em cada uma das zonas das cartas de paisagem homogênea urbana. Isso é possível, pois os dois mapas estão na mesma projeção e datum permitindo uma sobreposição dos mesmos, e conseqüentemente uma sobreposição dos dados. 


\subsection{Associacão dados do censo}

A carta de áreas homogêneas urbanas foi realizada a partir da interpretação de fotografias aéreas do ano de 2001, e o último censo foi realizado no ano de 2000 , e este foi disponibilizado em formato digital tanto de mapas quanto de dados para as cidades em estudo.

Como as áreas do censo não são condizentes com as áreas da carta de áreas homogêneas, foi realizada a interpolação dos dados explicados acima.

Como passamos a trabalhar com as áreas da chave de interpretação aumentamos as áreas que possuem dados, e limitamos os tipos de uso para 18, assim foi possível alem da analise espacial, temos uma analise de dados compilados em forma de tabelas e gráficos que nos auxiliam o entendimento da sócio demografia da região.

Assim, nos itens abaixo teremos os dados de domicilio, população, renda, esgoto e água nas zonas da carta de áreas homogêneas urbanas; e em números agregados por tipo de uso da terra. Foram considerados para os gráficos e tabelas, somente as áreas que diziam respeito a uso urbano, dado que o foco é esse tipo de uso. Nas cartas, temos os dados para todos os tipos de uso, pois a carta ficaria sem informação em algumas áreas nesse caso.

\subsubsection{Domicílios}

Com os dados dos setores censitários interpolados às áreas da carta de áreas homogêneas urbanas, realizamos o mapa de densidade populacional a partir da formula: domicílios particulares permanentes/área $\left(\mathrm{km}^{2}\right)$. 
Densidade de domicilios

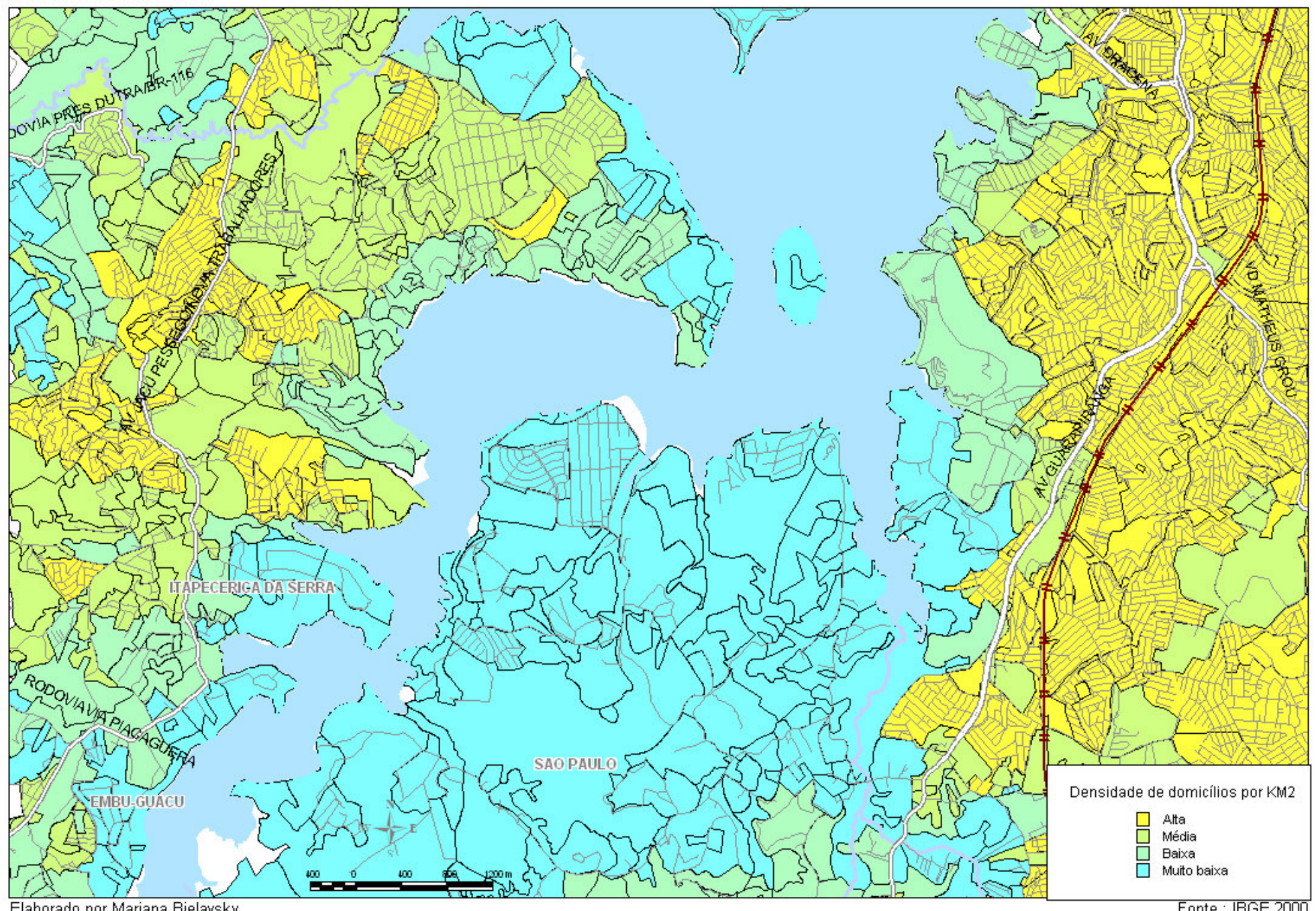

Figura 27 - Densidade de domicílios 


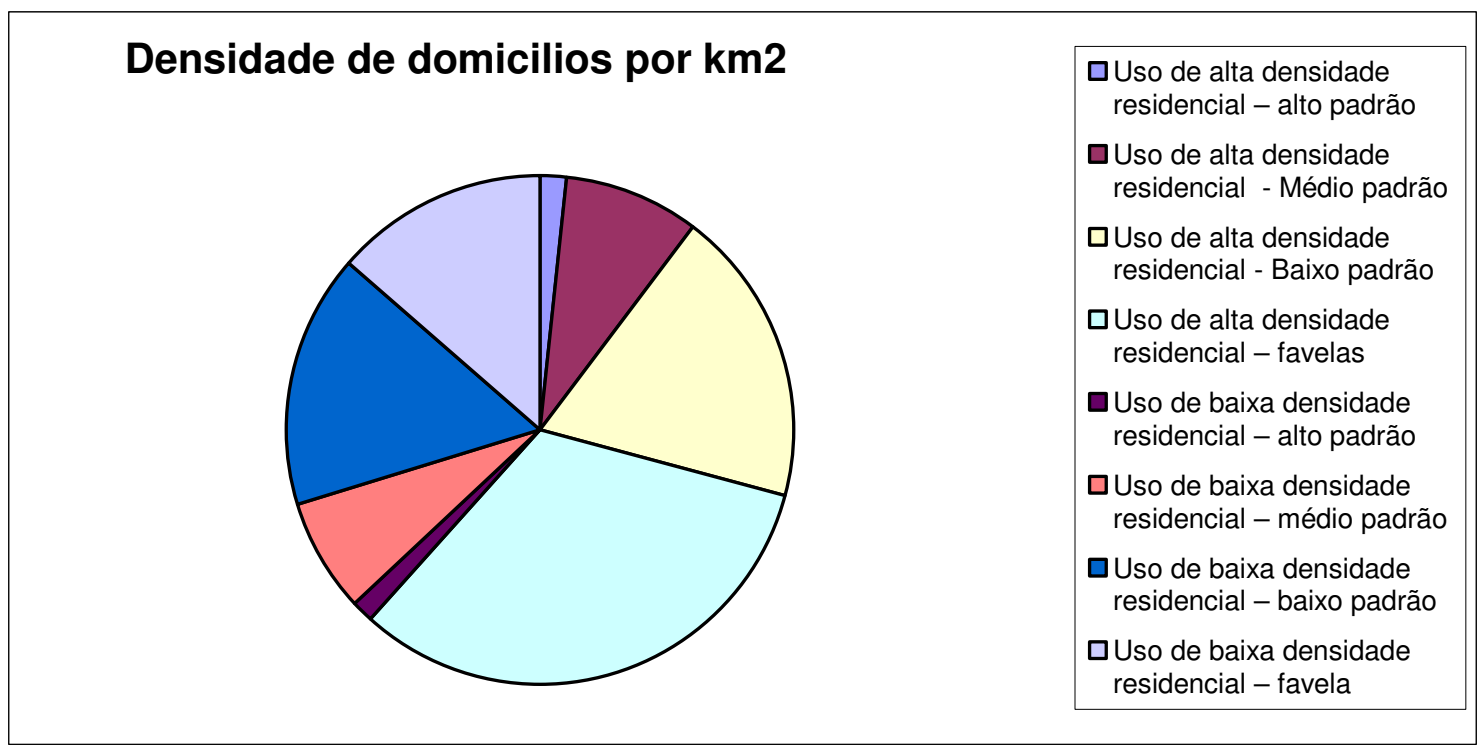

\section{Gráfico 1 - Densidade de domicílios 2000}

\section{Domicilios por tipo de uso}

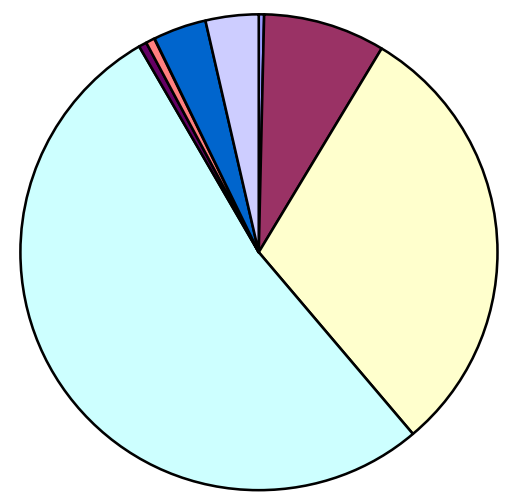

$\square$ Uso de alta densidade residencial - alto padrão

$\checkmark$ Uso de alta densidade residencial - Médio padrão

$\square$ Uso de alta densidade residencial - Baixo padrão

$\square$ Uso de alta densidade residencial - favelas

- Uso de baixa densidade residencial - alto padrão $\checkmark$ Uso de baixa densidade residencial - médio padrão

$\square$ Uso de baixa densidade residencial - baixo padrão

$\checkmark$ Uso de baixa densidade residencial - favela

\section{Gráfico 2 - Domicílios por tipo de uso}

Fonte (dois gráficos) IBGE 2003 


\begin{tabular}{|c|c|c|c|c|c|c|}
\hline Tipo de uso & Area $(\mathrm{km})$ & População & Mulheres & Homens & Domicilios & Densidade domicilios /km2) \\
\hline & $\#$ & \# & \# & \# & \# & \\
\hline \multirow{10}{*}{$\begin{array}{l}\text { Uso de alta densidade residencial - alto padrão } \\
\text { Uso de alta densidade residencial - Médio padrão } \\
\text { Uso de alta densidade residencial - Baixo padrão } \\
\text { Uso de alta densidade residencial - favelas } \\
\text { Uso de baixa densidade residencial - alto padrão } \\
\text { Uso de baixa densidade residencial - médio padrão } \\
\text { Uso de baixa densidade residencial - baixo padrão } \\
\text { Uso de baixa densidade residencial - favela } \\
\text { Clube, área de lazer } \\
\text { Chácara }\end{array}$} & 1,222030535 & 1004 & 536 & 468 & 270 & 220 \\
\hline & 7,37838663 & 32319 & 16686 & 15633 & 8758 & 1177 \\
\hline & 12,24293048 & 117830 & 60355 & 57476 & 31182 & 2541 \\
\hline & 12,48736887 & 207581 & 106661 & 100920 & 54701 & 4379 \\
\hline & 2,56394662 & 1843 & 922 & 921 & 490 & 189 \\
\hline & 0,68667064 & 2510 & 1231 & 1279 & 653 & 952 \\
\hline & 1,75259975 & 14649 & 7372 & 7277 & 3805 & 2170 \\
\hline & 1,948788512 & 13941 & 6997 & 6944 & 3598 & 1846 \\
\hline & 1,880220887 & 2234 & 1119 & 1115 & 583 & 309 \\
\hline & 0,666692683 & 183 & 90 & 93 & 46 & 68 \\
\hline Total & 43 & 394094 & 201969 & 192126 & 104087 & 2426 \\
\hline
\end{tabular}

\begin{tabular}{|c|c|c|c|c|c|c|c|c|c|c|}
\hline Domicilios particulares permanentes & \multicolumn{2}{|c|}{ Domicilios casa } & \multicolumn{2}{|c|}{ Domicilios apartamento } & \multicolumn{2}{|c|}{ Domicilios proprio quitado } & \multicolumn{2}{|c|}{ Domicilios alugado } & \multicolumn{2}{|c|}{ Outros } \\
\hline \# & $\#$ & $\%$ & $\#$ & & $\#$ & & & & $\#$ & $\%$ \\
\hline 269 & 158 & $59 \%$ & 110 & $41 \%$ & 209 & $78 \%$ & 30 & $11 \%$ & 30 & $11 \%$ \\
\hline 8684 & 7965 & $92 \%$ & 431 & $5 \%$ & 6039 & $70 \%$ & 1222 & $14 \%$ & 1423 & $16 \%$ \\
\hline 31108 & 29875 & $96 \%$ & 360 & $1 \%$ & 21919 & $70 \%$ & 4936 & $16 \%$ & 4253 & $14 \%$ \\
\hline 54676 & 52103 & $95 \%$ & 931 & $2 \%$ & 36531 & $67 \%$ & 9723 & $18 \%$ & 8423 & $15 \%$ \\
\hline 484 & 470 & $97 \%$ & 1 & $0 \%$ & 358 & $74 \%$ & 61 & $13 \%$ & 65 & $13 \%$ \\
\hline 653 & 650 & $100 \%$ & 1 & $0 \%$ & 508 & $78 \%$ & 89 & $14 \%$ & 56 & $9 \%$ \\
\hline 3803 & 3654 & $96 \%$ & 7 & $0 \%$ & 2807 & $74 \%$ & 523 & $14 \%$ & 473 & $12 \%$ \\
\hline 3597 & 3402 & $95 \%$ & 6 & $0 \%$ & 2563 & $71 \%$ & 327 & $9 \%$ & 706 & $20 \%$ \\
\hline 581 & 564 & $97 \%$ & 5 & $1 \%$ & 439 & $76 \%$ & 71 & $12 \%$ & 71 & $12 \%$ \\
\hline 46 & 45 & $99 \%$ & 0 & $0 \%$ & 34 & $74 \%$ & 3 & $6 \%$ & 9 & $20 \%$ \\
\hline 103901 & 98887 & & 1852 & & 71408 & & 16984 & & 15509 & \\
\hline
\end{tabular}

\section{Tabela 2 - Domicílios censo 2000}

Fonte IBGE 2003 
Podemos observar que as áreas que os usos residenciais de alta e baixa densidade são proporcionais. Calculando a proporção do numero de domicílios pela área para obtermos a densidade, com relação às áreas ocupadas por alta e baixa densidade de domicílios. O resultado nos mostra que as áreas que selecionamos na carta de áreas homogêneas urbanas são condizentes com os dados oficiais do censo.

A carta de densidade de domicílios (figura 27) nos confirma o dado, as regiões que são mais densas são as leste e oeste ao reservatório, apresentando uma grande mancha amarela (alta densidade) nessas duas áreas. Já a sul temos uma densidade de domicílios muito baixa, dado o tipo de uso que é principalmente vegetação. Essa comparação é observada analisando as ilustrações 25 (áreas homogêneas urbanas) e 27 (densidade de domicílios por áreas homogêneas urbanas).

Podemos observar também que a maior parte da população reside em áreas de baixo padrão e em favelas, em alta densidade. O que era esperado, já que temos uma grande quantidade desses domicílios.

Outro fator que podemos observar nas tabelas acima, é que a área é quase totalmente coberta por casas, havendo poucos apartamentos que nem chegam a ser visíveis pelas fotografias.

Uma média de $70 \%$ em todos os tipos de usos da área tem como tipo de aquisição o próprio já quitado, os demais $30 \%$ são divididos entre alugados e outros, que podem ser cedidos ou até mesmo invadidos.

Essa informação é ressaltada com o fato de que boa parte dos domicílios existentes na área são loteamentos que antes eram de chácaras e baixo padrão. Essa mudança pode ser observada nas cartas de uso da terra de 1962 a 1994.

Outro dado interessante, é que a população de homens e mulheres, está relativamente equilibrada. Havendo pouca diferença na quantidade, entre os tipos de uso, não havendo um numero sempre maior de homens ou de mulheres. 
Os domicílios existentes são próprios das pessoas ali residentes, Porém muitas vezes são loteamentos clandestinos em locais de proteção ao manancial. Como o censo apenas faz a contagem de domicílios existentes, não leva em conta a clandestinidade ou ruptura à lei, na localização dos domicílios.

\subsubsection{Esgoto e áqua}

O IBGE disponibiliza os dados referentes a residências com canalização de água

e rede de esgoto. Como nossa área de estudo é de proteção aos mananciais e teoricamente não deveria haver uso urbano acentuado, foi interessante fazermos a interpolação desses dados também, onde obtivemos o seguinte resultado: 


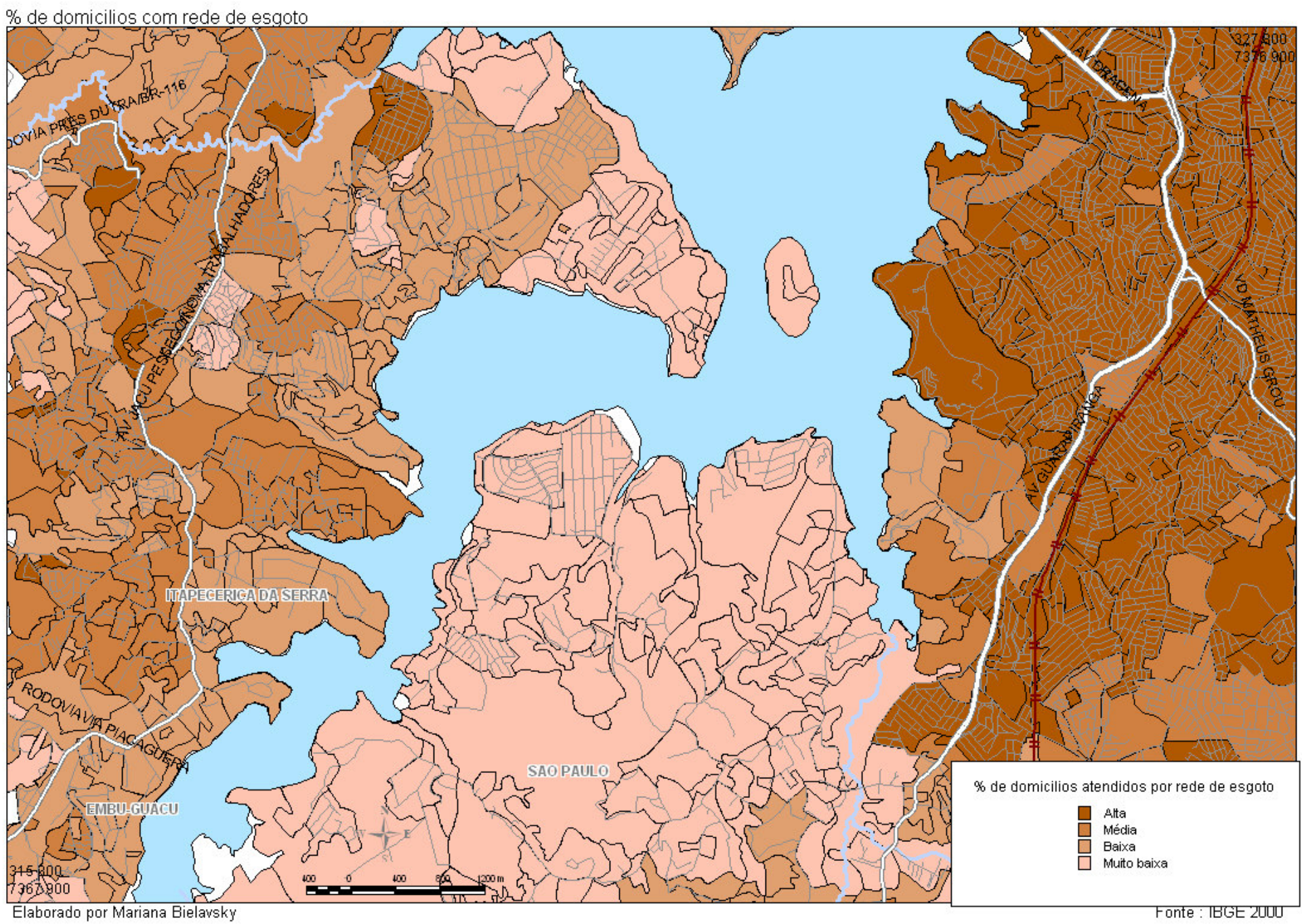

Figura 28 - Rede de esgoto 


\begin{tabular}{|c|c|c|c|}
\hline Tipo de uso & Domicilios particulares permanentes & abastecimento de água - rede & não canalizada \\
\hline Uso de alta densidade residencial - alto padrão & 269 & 252 & $\overline{17}$ \\
\hline Uso de alta densidade residencial - Médio padrão & 8684 & 8492 & 192 \\
\hline Uso de alta densidade residencial - Baixo padrão & 31108 & 29965 & 1143 \\
\hline Uso de alta densidade residencial - favelas & 54676 & 53668 & 1009 \\
\hline Uso de baixa densidade residencial - alto padrão & 484 & 401 & 83 \\
\hline Uso de baixa densidade residencial - médio padrão & 653 & 633 & 20 \\
\hline Uso de baixa densidade residencial - baixo padrão & 3803 & 3567 & 236 \\
\hline Uso de baixa densidade residencial - favela & 3597 & 3255 & 342 \\
\hline Clube, área de lazer & 581 & 533 & 47 \\
\hline Chácara & 46 & 26 & 19 \\
\hline
\end{tabular}

\begin{tabular}{|c|c|c|}
\hline esgotamento sanitário - rede geral de esgoto & sem esgoto & $\%$ sem esgoto \\
\hline 247 & 23 & $8 \%$ \\
\hline 6073 & 2611 & $30 \%$ \\
\hline 14370 & 16737 & $54 \%$ \\
\hline 43990 & 10686 & $20 \%$ \\
\hline 9 & 476 & $98 \%$ \\
\hline 24 & 629 & $96 \%$ \\
\hline 394 & 3409 & $90 \%$ \\
\hline 288 & 3309 & $92 \%$ \\
\hline 142 & 438 & $75 \%$ \\
\hline 3 & 42 & $93 \%$ \\
\hline
\end{tabular}

\section{Tabela 3 - Esgoto e água}

Fonte IBGE 2003

A carta de quantidade de domicílios com rede de esgoto pluvial nos mostra que a maior parte da área apresenta rede de esgoto nas áreas de maior densidade de domicílios que são as áreas leste e oeste da carta.

Observamos pela tabela acima que a distribuição de água canalizada é quase que total, somente pouco abastecida em alguns pontos como chácaras e alguns loteamentos de baixo padrão, pelo distanciamento que esses se encontram dos vetores de crescimento da área.

Com relação ao esgoto, a área não é bem servida, as regiões de alta densidade possuem um numero alto de residências com essa infra-estrutura principalmente em médio e alto padrão; correspondendo a 30\% e $8 \%$ respectivamente. Porém, $20 \%$ das áreas de favela e $54 \%$ das áreas de baixo padrão não possuem rede de esgoto. 
Acreditamos que esse resultado, onde as áreas de baixo padrão apresentam mais esgotamento que as de baixo, dá-se pelos fatos que as residências de alto padrão, assim como as chácaras apresentarem muitas vezes fossas sépticas e outros tipos de esgoto que não são de rede da Sabesp. Alem disso, a infraestrutura acompanha o crescimento da cidade, assim as áreas que são os vetores de crescimento são que a recebem primeiro.

O único dado que destoa um pouco do esperado, é o grande atendimento que a área leste possui em termos de esgotamento. As áreas mais pobres, e também mais densas, são as que possuem mais residências com esgoto, Porém coincide com os o fato que essa área é um vetor de crescimento e por isso recebe infraestrutura do governo.

Vale a ressaltar que estamos trabalhando com porcentagem de esgotamento sanitário, ou seja, do total de domicílios que existem quantos não possuem esgoto. Como as áreas de baixo padrão e favelas são as mais densas, que possuem mais domicílios por área. Assim o resultado apesar de aparentemente bom em termos de esgotamento, ainda é preocupante, pois $20 \%$ de 54676 são muito mais domicílios que $30 \%$ de 8684 (como mostra a tabela 5). Portanto o que vemos é que as áreas mais densas são as mais atendidas, Porém dada a quantidade de domicílios ainda é muito grande o numero de residências sem esgoto próximo ao reservatório.

Outro fator são os programas de urbanização realizados nas favelas próximas ao reservatório e outras bacias na região do Guarapiranga, como o programa Guarapiranga realizado em 1998 com financiamento do BIRD, que teve como uma das principais metas a rede de esgoto das favelas e loteamentos da região.

\subsubsection{Renda}

Outro dado que interpolamos do censo e que nos permite um melhor entendimento da área e das pessoas que ali moram é a renda. Como já vimos, 
trabalhamos com renda média mensal do responsável pelo domicilio, que é o dado que o censo disponibiliza.

Esse mapa (figura 29) foi realizado a partir do dado da quantidade de responsáveis pelo domicilio/renda média mensal por faixas de renda em salários mínimos do ano de 2000, referente a 151 reais.

Para um melhor entendimento dessa variável, foram separadas classes de renda a partir desses salários mínimos. Juntando assim algumas faixas temos as classes de renda, sugeridas pelo próprio IBGE.

\section{Classes de renda IBGE}

Classe $\mathrm{E}$ - ate 1 salário mínimo

Classe D - de 1 a 3 salários mínimos

Classe $\mathrm{C}$ - de 3 a 5 salários mínimos

Classe B2 - de 5 a 10 salários mínimos

Classe B1 - de 10 a 15 salários mínimos

Classe A2 - de 15 a 20 salários mínimos

Classe A1 - mais de 20 salários mínimos

Tabela 4 - classes de renda IBGE

Fonte : IBGE 2003 
Renda média mensal do responsável pelo domicilio - interpolçao dados censo x paisagens homogêneas urbanas - 2000

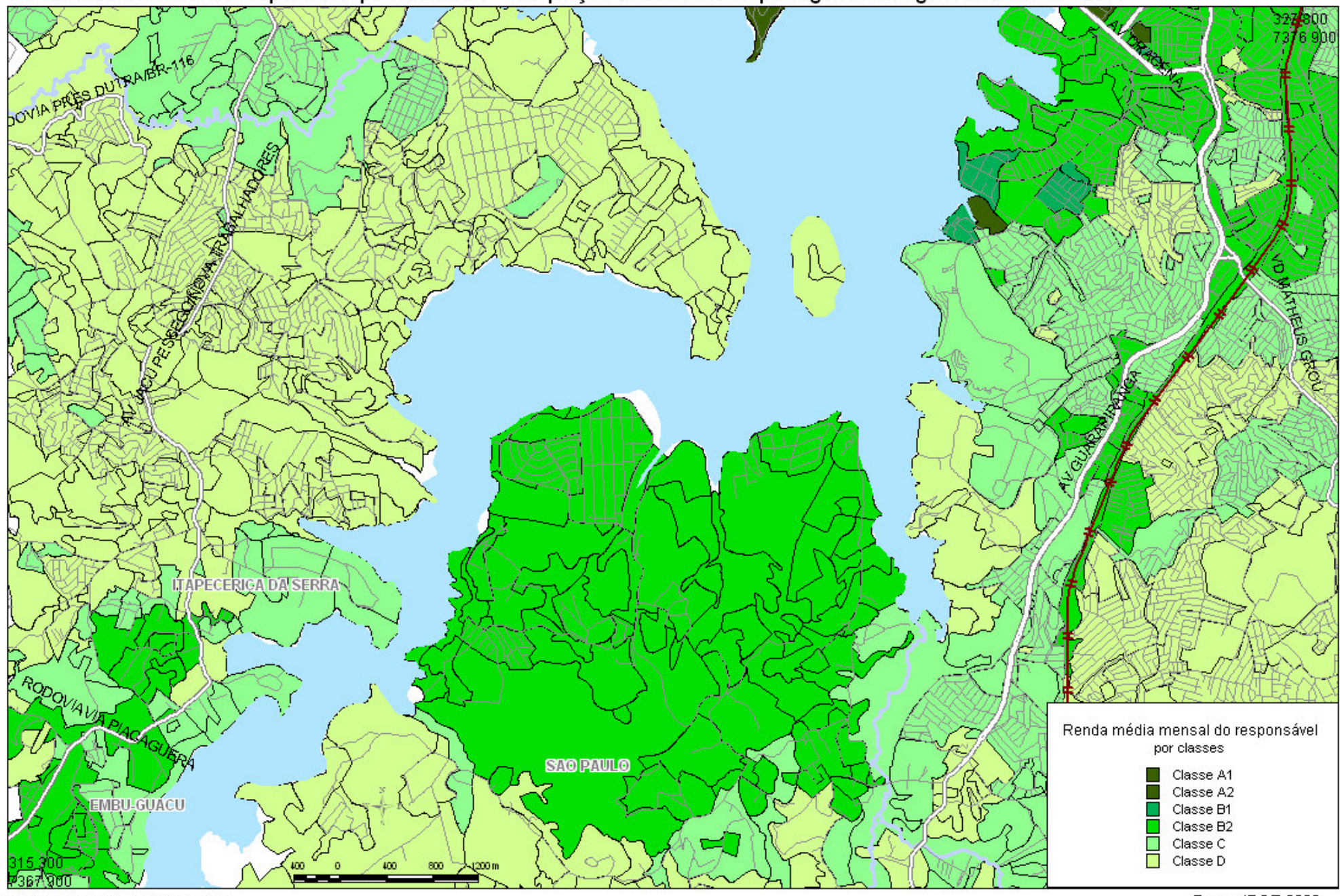

Elaborado por Mariana Bielavsky

Fonte: IBGE 2000

\section{Figura 29 - Renda Média}


Socio demográfia - Carta de paisagens homogenias urbanas

População e domicilios

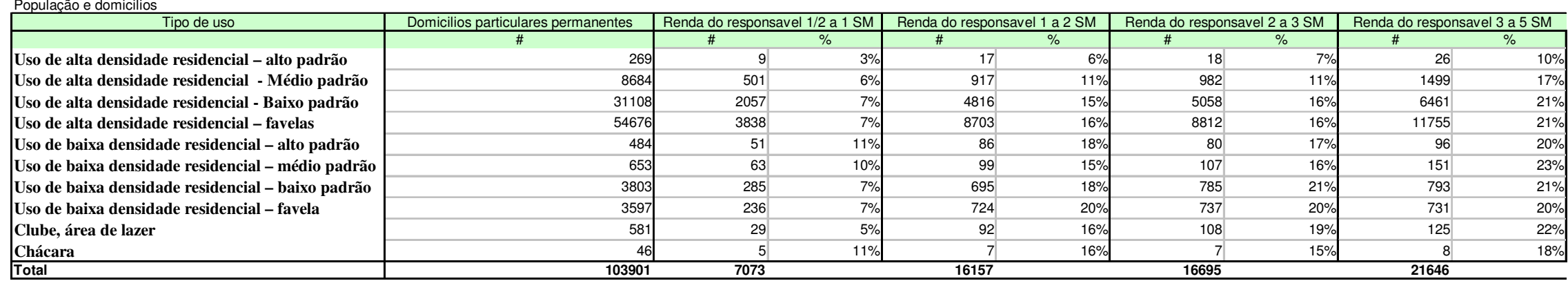

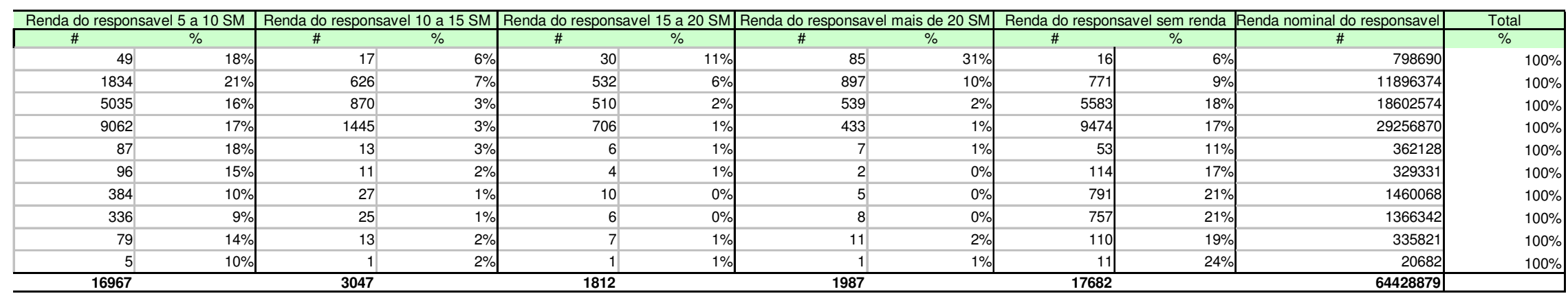

Tabela 5 - Renda

Fonte IBGE 2003 


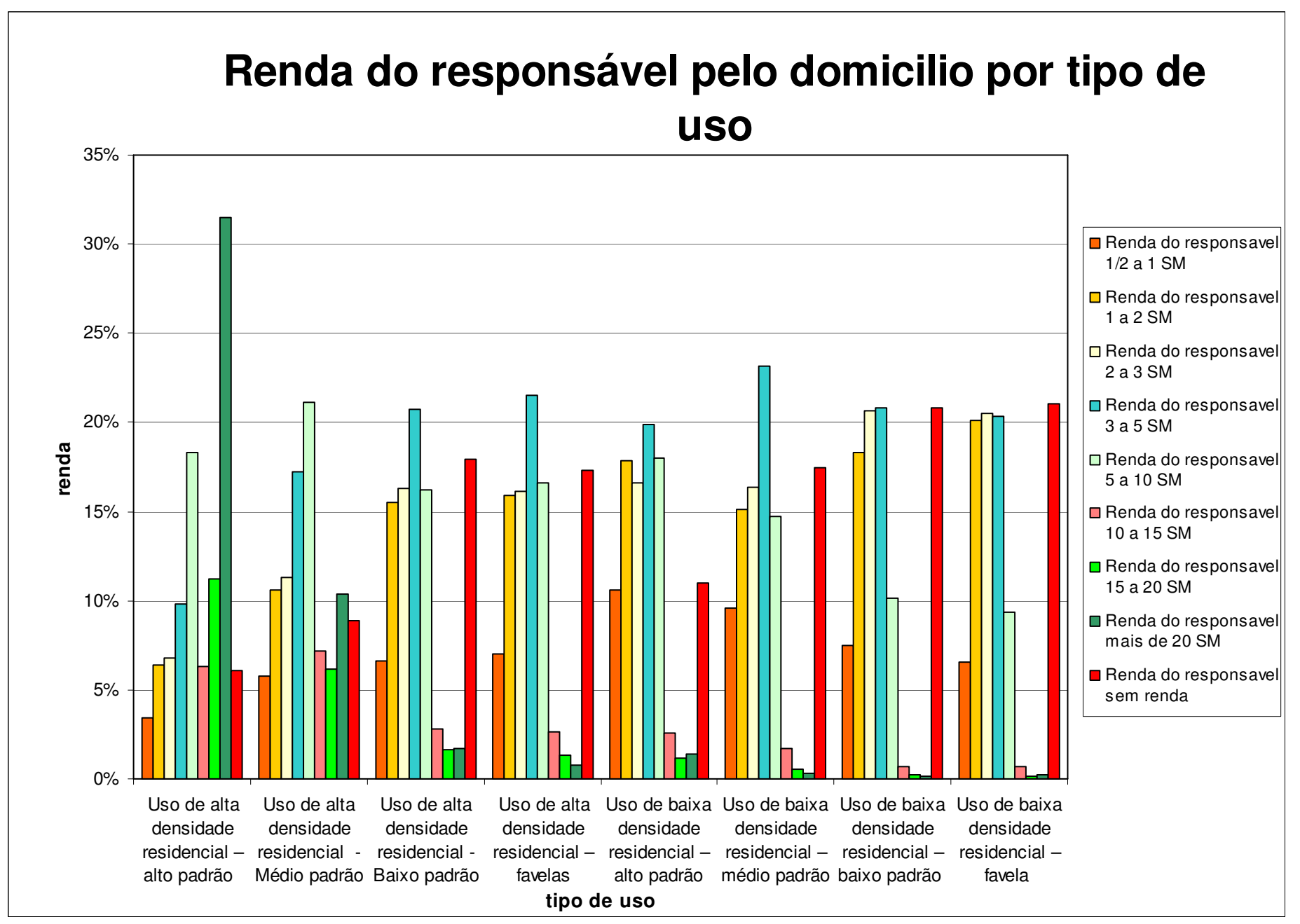

\section{Gráfico 3 - Renda média do responsável}

Fonte IBGE 2003 
Pela carta de renda média mensal do responsável pelo domicilio podemos observar que as áreas de renda mais baixa são as áreas a leste e a oeste do reservatório, que são as zonas onde encontramos as duas maiores manchas verde claras, mostrando a baixa renda da população.

A região sudeste apresenta uma renda maior, assim como as regiões a norte e a sul do reservatório, que são exatamente as áreas em que temos residências de alto padrão segundo a carta de áreas homogêneas urbanas. Essas residências e essa alta renda têm ligação com o tipo de uso anterior ao grande crescimento urbano da área a partir de década de 70 , que era um uso voltado ao lazer com loteamentos de alto padrão, chácaras, marinas entre outros.

Podemos observar que os dados do censo também coincidem com a interpretação da foto. Os usos de alto padrão de alta densidade são o que apresentam maior renda, chegando ate a faixa de mais de 20 salários mínimos. $O$ de alto padrão e baixa densidade, também apresentam uma renda mais alta de até 5 a 10 salários mínimos, que é considerado classe B pelo IBGE.

Os usos de médio padrão condizem com as classes $\mathrm{C}$ e $\mathrm{B}$, de 3 a 10 salários mínimos, havendo uma constância na renda das áreas de alta densidade, não havendo muitos domicílios com renda baixas ou sem renda. Existem domicílios que se declaram sem renda com muitos nas áreas de baixa renda e favela, independente da densidade da área.

O que podemos observar na interpolação dos dados de renda do censo de 2000 para a carta de áreas homogêneas urbanas de 2001, é que a área realmente comporta uma grande quantidade de domicílios de renda baixa ou ate mesmo que se declaram sem renda. E essa estrutura espacialmente é a mesma da carta de áreas homogêneas, onde as áreas que foram interpretadas como de baixo padrão e favelas se apresentam com renda baixa e as de alto e médio padrão também com rendas condizentes. 
Como vimos no resultado da carta de áreas homogêneas urbanas, a área leste ao reservatório apresenta uma grande densidade e residências que apontam baixa renda, o mesmo acontecendo a noroeste do reservatório. A sudoeste temos uma renda mais alta e uma densidade mais baixa e por fim a sul da represa temos uma renda alta e uma densidade baixa. 


\section{7 Áreas homogêneas urbanas e sócio demografia}

Atualmente as margens do reservatório Guarapiranga estão quase totalmente tomadas por urbanização, assim como próximo aos rios que o abastecem. Esse crescimento da cidade e o detalhamento de tipos de urbanização são o resultado que obtivemos na carta de paisagens urbanas realizada para o ano de $2001 \mathrm{com}$ fotografias aéreas.

O resultado dessa carta nos mostra que além da área ser bastante urbanizada, essa é concentrada ao leste e oeste do reservatório e é principalmente de baixa renda. Ainda existem domicílios de alta e média renda em quantidade bem menor, assim como outros tipos de uso da terra.

A carta de paisagens urbanas, junto com os dados do censo, nos mostra uma realidade preocupante na área, que é a grande quantidade de pessoas de baixa renda, e a alta densidade de construções de baixo padrão.

Essa população foi segregada para a região da bacia do Guarapiranga muitas vezes por falta de opção de moradia, migrando cada vez mais para as margens da cidade. Tal migração coincide com uma área de proteção aos mananciais e que é responsável pelo abastecimento de água da zona sul da cidade de São Paulo.

Muitas dessas moradias são resultados de divisões de lotes maiores. Esses lotes eram de construções de alto padrão, cuja residência não ocupava a totalidade do lote havendo uma parte do mesmo ocupado com vegetação e outros tipos de uso não urbanos como cultura ou solo exposto.

O uso de loteamentos de baixo padrão cresce com a alteração do uso da área do reservatório Guarapiranga, de lazer para alternativa de moradia, a partir da década de 1970/80, tornando-se assim um uso irregular da área, que está sob a lei de proteção aos mananciais desde 1975.

Até a década de 70/80, não havia uma quantidade grande habitantes morando nessa região, como mostra a carta de uso da terra de 1974. Somente a partir de 1994 é que passamos a ver uma ocupação urbana maior da área. O crescimento da cidade na década de 70 que segregou muitas pessoas das áreas mais centrais 
da cidade e as levou para zonas informais da mesma, chegando a criar favelas na área, e esse crescimento da urbanização nas áreas informais aumentou nas décadas seguintes ate atingir áreas ambientalmente frágeis, com a proximidade do reservatório Guarapiranga e dos rios que o abastecem.

Porém a necessidade de moradia das pessoas segregadas, muitas vezes fala mais alto que as leis, o que torna essa área ocupada por urbanizações não compatíveis com o seu uso ambiental de manancial de abastecimento.

Essa população que se move para a parte informal da cidade, muitas vezes não encontra nessa área infra-estrutura para a sua moradia, tanto em termos de construção (favelas e autoconstrução) que são moradias improvisadas sem segurança nem viabilidade do terreno (muitas vezes erodibil e de alta declividade) quanto de infra-estrutura básica, como rede de esgoto.

Em uma contradição entre o uso ambiental e o uso urbano, muitas vezes o próprio governo coloca a disposição infra-estrutura, isso quando não a iniciativa privada. Entre os itens de infra-estrutura, podemos salientar as escolas, clubes, bancos, supermercados, vias asfaltadas, linhas de tens que encontramos na área de estudo, favorecendo a vivencia de pessoas nessas áreas.

Essa estrutura ajuda manter a população e muitas vezes atrai mais pessoas, criando assim como MILTON SANTOS (1998) coloca "Conforme a infra-estrutura é fornecida nessas novas áreas informais, as mesmas ganham valor. O que leva a uma nova segregação da população mais pobre, para locais ainda mais distantes". A população que ali vive apresenta risco tanto para sua própria vida, como para a vida do reservatório. Pois como vimos na carta de áreas homogêneas urbanas de 2001, na área a leste do reservatório há construções de baixo padrão muito próximas ao reservatório, o que causa muitas vezes assoreação da represa, diminuição da área útil da mesma. O que futuramente pode comprometer, e já vem comprometendo, o abastecimento de água tanto em qualidade e quantidade como em custo para o consumidor final. 


\section{Considerações Finais}

Essa pesquisa apresentou a dinâmica de crescimento de uso da terra nos últimos 40 anos. De 1962 até 1994 foi realizada uma interpretação do uso da terra em uma chave de interpretação que apresenta o uso de vegetação e o uso urbano, e para o ano de 2001 houve uma intensificação da observação do intra-urbano.

O que pudemos observar é que a partir de 1974 temos uma transformação do uso da área de vegetação para uso residencial, ao contrario do que temos nos anos anteriores. Essa urbanização aumenta nessa década, dado o fenômeno de segregação, em sua maioria pelo fato de o espaço ter uma valorização diante de alguns tipos de infra-estrutura e de centralidade dos usos urbanos.

Antes da década de 1970/80, a região do reservatório Guarapiranga, era voltada ao uso de lazer, muitas famílias de classes altas viam essa área como uma alternativa de lazer muito próxima à cidade.

Com a alteração da vazão do Rio Pinheiros, houve uma desvalorização da área, mudando assim o seu tipo de uso. Esse passou cada vez mais a ser uma alternativa de moradia para as classes mais pobres, que eram cada vez mais levadas a cidade informal que crescia as margens da cidade formal.

Nessa mesma década de 70, começou a haver uma preocupação maior com 0 meio ambiente, entre outras medidas criou-se a lei de proteção aos mananciais que termina por ser alterada e regulamentada para a lei atual de 1997.Essa lei está em vigor, porem não pode ser aplicada em nenhuma bacia, pois cada bacia precisa ter uma lei especifica (regulamentação), que detalhe entre outras coisas as diretrizes e normas de políticas de mananciais para cada caso especifico de cada bacia. Por ser uma região responsável pelo abastecimento de água de boa parte da população da região sul de São Paulo, nossa área de estudo se encontra sob vigência dessa lei.

Apesar das leis e da incompatibilidade do uso urbano as margens da represa, essa área possui uma grande quantidade de vias de acesso, grandes avenidas como Teotônio Vilela, Estrada do M'Boi Mirim, Robert Kennedy, que facilitam a 
locomoção tanto de carros como do transporte público. Ainda nessa região temos uma linha de trem da CPTM, que auxilia ainda mais o transporte na área.

O fator transporte como já vimos, é um dos principais para ao aumento da urbanização da região. Pois as pessoas procuram lugares pra morar em que os lotes são mais baratos, porém que permitam deslocamento para as áreas centrais onde estão os empregos de muitas dessas pessoas.

Porém é essa própria infra-estrutura que atrai cada vez mais pessoas de baixa renda para o local. Como vimos na distribuição dos estabelecimentos comerciais e de serviços, além das vias na região existem escolas (publicas e privadas), bancos, supermercados e outras tantas atividades que são essenciais para a vida do bairro. O que gera uma centralidade local e auto-suficiente para esses bairros. Por se tratar de uma metrópole, São Paulo não apresenta mais uma centralidade única, cada região possui sua própria centralidade, e essa mesma ajuda a manter, senão atrair mais pessoas para a região.

Assim, mesmo sendo uma área ambientalmente frágil, ela é populosa e povoada, tanto por pessoas quanto por infra-estrutura, que cada vez mais acolhe pessoas segregadas das regiões mais centrais. E por sua vez leva pessoas dessa região para lugares mais distantes ainda da cidade formal.

A carta de áreas homogêneas urbanas nos mostra o uso intra-urbano da área em estudo. Esses padrões de moradia foram detalhados sob as fotografias área, onde obtivemos 8 (oito) padrões de uso residencial urbano - alto, médio, baixo e favela em áreas pouco densas e muito densas.

Essa interpretação detalhada do uso urbano nos mostrou que a área leste é muito mais densa e pobre que as demais. Seguida pela área oeste, que apresenta bastante urbanização de baixo e médio padrão. Já as áreas sul e norte, apresentam grande quantidade de uso de vegetação.

O que nos mostra que as áreas oeste e leste são os principais vetores de crescimento urbano da cidade na área de estudo. Esses possuem grandes vias de transporte, estabelecimentos comerciais e de serviços, infra-estrutura urbana 
como água e esgoto (não em sua totalidade) que auxiliam o crescimento para essas duas regiões.

Em termos de infra-estrutura, vimos que a região é bem abastecida com relação à água, porém com relação ao esgoto vimos que as áreas de baixo padrão são as mais atendidas, entretanto dada a quantidade de domicílios que temos nessas áreas, muito mais que nas regiões de médio e alto padrão, ainda é muito grande o numero de residências sem esgoto próximo ao reservatório.

Segundo o censo de 2000, a área possui uma alta densidade de domicílios, e estes por sua vez muitas vezes possuem moradores com rendas baixas, principalmente a leste da represa, havendo alguns focos também a oeste. As demais áreas não apresentam um uso acentuado urbano, e quando há, são geralmente de tipo de urbanização de alto padrão e com renda condizente a esse tipo.

Vemos ainda nas áreas muito urbanizadas favelas e moradias de baixo padrão. Estas se encontram muito próximas ao reservatório (área protegida por lei),e por sua vez são áreas que comportam um numero grande de habitantes e de moradias, tornando a área muito densa. Essas mesmas áreas apresentam infraestrutura como bancos, escolas, avenidas de grande porte e linha de trem entre outros.

Os fatores colocados acima juntamente com as cartas de uso da terra e de áreas homogêneas urbanas nos mostram que a mancha urbana cresceu de uma forma não planejada, e que não condiz com o tipo de uso ideal para as áreas, principalmente após a década de 70 , sendo cada vez mais tomada por tipos de construção residencial de baixo padrão, por pessoas de baixa renda, vendo essa área como única maneira de obter uma moradia, mesmo que às margens da cidade.

Quando colocamos que a área teve um crescimento não planejado, isso diz respeito ao tipo de uso que a área deveria comportar por se tratar de uma área de proteção ambiental. Pois sempre nas cidades há um planejamento mesmo que não intencional, é o planejamento mercadológico. Onde a população busca áreas 
para morar e o comercio e serviços se estabelecem próximos (a busca de clientes), havendo esses dois fatores já vemos um crescimento urbano da área. $E$ muitas vezes o governo cede a esse crescimento abastecendo a região com infraestrutura (água, luz, esgoto etc.). Porém por se tratar de uma região ambientalmente frágil, deveria haver um planejamento urbano e ambiental realizado pelo governo visando preservar essa área como manancial de abastecimento da cidade de São Paulo e região.

Não podemos simplesmente acreditar que é possível retirar as pessoas dessa região, por essa área se encontrar em uma metrópole que possui movimento de segregação dinâmico, e por a área já apresentar uma infra-estrutura, outras pessoas acabam por habitar o local, já que o problema ocorre na cidade inteira e essa área é um vetor de crescimento urbano.

Também não podemos acreditar que esse tipo de uso não apresenta restrições para a utilização do manancial como abastecimento de água. Pois a proximidade ao reservatório de residências pode levar a erosões e movimentos de massa que o assoreia, baixando sua capacidade e aumentando o preço final da água, que passa a necessitar cada vez mais de tratamentos para o seu consumo.

Os mananciais, por se encontrarem em regiões longe do centro da cidade, são alvo fácil para a segregação das pessoas, que vêem nessa região uma solução para os problemas de moradia. A própria dinâmica da cidade e do mercado, criam as possibilidades para esse uso urbano. Porém, se não planejada e controlada essa urbanização pode deixar de ser uma solução para parte das pessoas que moram, para se tornar um problema urbano local (com enchentes, deslizamentos) e da própria metrópole.

Assim não podemos observar essa área somente pelo enfoque urbano, ou pelo enfoque ambiental. Essa região é uma soma desses dois olhares - A necessidade da população obter uma moradia (digna) e a cidade de receber o abastecimento de água em quantidade suficiente e de qualidade. 
Por fim essa pesquisa nos apresenta um alerta e um pedido de planejamento com um olhar holístico sobre a área, sendo ela um habitat e um fornecedor de recursos que a cidade como um todo usa, e ainda utilizará por varias gerações.

\section{Referências Bibliográficas}

ARAÚJO, Modelagem tridimensional de objetos cartográficos por estruturas octree e triangulação espacial. Dissertação (Mestrado) Instituto Militar de Engenharia, Rio de Janeiro, 1991

BERMAN, M. - Tudo que é sólido se desmancha no ar a aventura da modernidade São Paulo: Companhia das Letras, 1987

BURROUGH, P..; Mcdonnell, R. - Principles of Geographical Information Systems.New York: Oxford University Press, 1998. 332 p.

CAMPBELL, J. Mapping the land. Aerial imagery for land use information. [n.I.] resources publicatinons in geography, 1944.

CASTELLS (1983 in CORREA, R. O Espaço Urbano. São Paulo: Editora Ática, 1989)

CAVALHEIRO, F. - Urbanização e alterações ambientais. In NUCCI, J.C Qualidade Ambiental \& Adensamento Urbano, São Paulo, Humanitas, 235 p. 2001

CETESB COMPANHIA DE TECNOLOGIA DE SANEAMENTO AMBIENTAL Brasil, leis etc. Região metropolitana de São Paulo, proteção dos mananciais, zoneamento industrial - atualizado até 1989. São Paulo [s.n], 1989

COLLWEL, R. Manual of remote sensing: interpretacions and applications, Falls Church: American Soc. Photogrametry,1983

EMPLASA - Treinamento de interpretação de imagens de sensoramento remoto,São Paulo, 1979

FURQUIM, A. et al. Uso de ortofotcartas Digitais. Curitiba [sn], 1996 GOMES, O. - El médio físico y la planificacion. Madri. Cifca, 1978, VI e II 307 p. IBGE - Censo demográfico 2000 - agregado por setores censitários dos resultados do universo. Documentação de arquivo digital, Rio de Janeiro: 2003 JENSEN, J. Remote sensing of the enviroment - na earth resource perspective. [S.L]: Keith C. Clarke, 2000 
LANGENBUCH, J. A estruturação da Grande São Paulo; : estudo de geografia urbana, Rio de Janeiro, 1971354 p

LEFEBVRE, H. - O direito á cidade. São Paulo: Documentos, 1969 133p.

LEMOS, A. I., A metropolização nos países do terceiro mundo. In Revista do Departamento de Geografia n. 13 Humanitas, São Paulo, 1999

LISBOA, J. - Projeto de Banco de Dados para Sistemas de Informação Geográfica, Tese de mestrado, Universidade Federal de Viçosa (UFV), Departamento de Informática, Viçosa, 2001

LO AND FABER (1998) - apud. JENSEN, 2000

MALTA, C. - Cidades Brasileiras seu controle ou o caos. Editora Probel. São

Paulo 1994.

MANDANI, M.. - Sistema Integrado de Fotogrametria Digital em Windows NT Intergraph, Huntsville:[S.N], 19? TRADUÇAO Robson J. Rivera Augusto

MARCONDES, M. J. de A. - Cidade e Natureza - Proteção dos mananciais e exclusão social. São Paulo: Edusp, 1999

MACUS, M.G \& DETWYLER, T.R. - Urbanizacion and enviroment. Bermount/

Cal., Duxburg Press, 1972 286p.

MARCUSE, P. Enclaves yes, ghettoes no. Segregation and State. International seminar of segregation and the city. Cambirgde, Lincon Institute of land policy, 2001

McHARG, I. - Designs with nature. Nova lorque. Back edition. 1971, 198 p In

NUCCI, J.C - Qualidade Ambiental \& Adensamento Urbano, São Paulo,

Humanitas, 235 p. 2001

MONTEIRO , C.A.de F. Qualidade ambiental do reconcavo e regiões limitrofes.,

Salvador, Seplantec, 1987

MONTEIRO, C. A. de F. Geossistemas : a história de uma procura, São Paulo :

Contexto, 2000, 127p.

MONTEIRO, C. A. de F. - Teoria e Clima Urbano. Tese (Livre-Docência)

Departamento de Geografia FFLCH - USP, São Paulo 1975.

MONTEIRO (1986) - (apud. NUCCI, 2001) 
MONTEIRO, C. A. - Geografia e Ambiente In Revista Orientação N.5, São Paulo, 1984. Páginas 19 - 28.

NORTON, G.A. \& WALKER, B.H. A decision analysis approach to savanna management. Journal of Environmental Management., 1985

NOVO, E. M. L. - Sensoriamento remoto Princípios e aplicações. São Paulo: Editora Edgard Blücher, 1989

NUCCI, J.C - Qualidade Ambiental \& Adensamento Urbano, São Paulo, Humanitas, 235 p. 2001

ROLNIK, R.1992. Política ambiental e gestão da cidade (Apresentação). In: Prefeitura do Município de São Paulo/Secretaria Municipal de Planejamento , Cadernos de Planejamento, Diário Oficial do Município de São Paulo, ano 37, № 243 (Suplemento),.24.

ROLNIK, R; KOWARIK, L. SOMEKH, N. 1991. São Paulo: crise e mudança. 2 Ed. São Paulo. Brasiliense. 215 p.

SANTOS, R.F.; CARVALHAIS, H.B. \& PIRES, F. - Planejamento ambiental e sistemas de informações geográficas. Tese de mestrado, 1998

SANTOS, M. - Por uma nova geografia - da crítica da geografia a uma geografia crítica. São Paulo: Editora Hucitec, 1978 233p.

SANTOS, M. - A urbanização Brasileira, São Paulo: Hucitec, 1993

SANTOS, M. - Metrópole coorporativa fragmentada - o caso de São Paulo São Paulo: editora Hucitec, 1999

SÃO PAULO (ESTADO) - Lei numero 9.866/97 - decreto 43.022/98. Plano emergencial de recuperação dos mananciais da região metropolitana de São Paulo, v1, 1998

SÃO PAULO (ESTADO) - lei numero 9866/97 - uma nova política de mananciais, 1998

SASSEN, S. As Cidades na Economia Mundial, São Paulo: Studio Nobel, 1998. SEABRA, O., SPORL, C. A lei de proteção aos mananciais versus a pratica social de ocupação na bacia de Guarapiranga. São Paulo, 1997, Revista do departamento de Geografia n 11 São Paulo, p. 113-133, 1997 
SEHAB (SECRETÁRIA DE HABITAÇÃO E DESENVOLVIMENTO URBANO DO MUNICÍPIO DE SÃO PAULO), CONSÓRCIO JNS/HAGPLAN - Relatório de análise do projeto básico - programa de saneamento ambiental da bacia do Guarapiranga, São Paulo [s.n.], 1998

SERRA, G. O Espaço natural e a forma Urbana, São Paulo: Editora Nobel, 1987 TARIFA, J.R, ARMANI, G. Unidades climáticas naturais in: Os climas da cidade de São Paulo Tarifa, J.R, Azevedo, T. Orgs. FFLCH USP, São Paulo, 2001

VILELA, F. ROSS, J. Estudo Empírico da Fragilidade se um Ambiente Natural Antropizado: O Bairro do Parque Novo Santo Amaro e Seu Entorno Próximo in $\mathbf{X}$

Simpósio Brasileiro De Geografia Física Aplicada, Rio de janeiro, 2003

VILLAÇA, F. - O Espaço Intra-Urbano no Brasil. São Paulo: Editora Nobel, 1998

\section{Mapas}

IBGE - Base de informações por setor censitário - censo demográfico 2000 Cidade de São Paulo. Rio de Janeiro. 2002. Escala indeterminável 1 mapa + dados . 1 CD Rom

IBGE - Base de informações por setor censitário - censo demográfico 2000 Cidade de Embu - Guaçu. Rio de Janeiro. 2002. 1 mapa + dados. 1 CD Rom

IBGE - Base de informações por setor censitário - censo demográfico 2000 Cidade de Itapecerica da Serra. Rio de Janeiro. 2002. 1 mapa + dados. 1 CD Rom MULTISPECTRAL MAPAS DIGITAIS (EMPRESA) - Eixos de ruas de EmbuGuaçu, São Paulo, 20051 mapa. Escala 1:5000. 1 CD Rom

MULTISPECTRAL MAPAS DIGITAIS (EMPRESA) - Eixos de ruas de Itapecerica da Serra, São Paulo, 20051 mapa. Escala 1:5000. 1 CD Rom

MULTISPECTRAL MAPAS DIGITAIS (EMPRESA) - Eixos de ruas de São Paulo, São Paulo, 20051 mapa. Escala 1:5000. 1 CD Rom

MULTISPECTRAL MAPAS DIGITAIS (EMPRESA) - Fotografias aéreas de São Paulo. São Paulo, 2001 escala 1:15000 altura do vôo 2300 metros, fx 25 fotografias 2085 a 2099 , fx 26 fotografias 2236 a 2225, fx 27 fotografias 2280 a 2294, fx 28 fotografias 2392 a 2380, fx 29 fotografias 2422 a 2437, fx 30 fotografias 2512 a 2500 resolução 300 dpi formato do arquivo .tif. 3 CDs Rom.

MULTISPECTRAL MAPAS DIGITAIS (EMPRESA) - Hidrografia de Embu-Guaçu, São Paulo, 20051 mapa. Escala 1:5000. 1 CD Rom 
MULTISPECTRAL MAPAS DIGITAIS (EMPRESA) - Hidrografia de Itapecerica da Serra, São Paulo, 20051 mapa. Escala 1:5000. 1 CD Rom

MULTISPECTRAL MAPAS DIGITAIS (EMPRESA) - Hidrografia de São Paulo, São Paulo, 20051 mapa. Escala 1:5000. 1 CD Rom

MULTISPECTRAL MAPAS DIGITAIS (EMPRESA) - Limites de município do Brasil, São Paulo, 20051 mapa. Escala 1:5000. 1 CD Rom

MULTISPECTRAL MAPAS DIGITAIS (EMPRESA) - Praças de Embu-Guaçu, São Paulo, 20051 mapa. Escala 1:5000. 1 CD Rom

MULTISPECTRAL MAPAS DIGITAIS (EMPRESA) - Praças de Itapecerica da Serra, São Paulo, 20051 mapa. Escala 1:5000. 1 CD Rom

MULTISPECTRAL MAPAS DIGITAIS (EMPRESA) - Praças de São Paulo, São Paulo, 20051 mapa. Escala 1:5000. 1 CD Rom

MULTISPECTRAL MAPAS DIGITAIS (EMPRESA) - Viário principal de ruas de São Paulo, São Paulo, 20051 mapa. Escala 1:5000. 1 CD Rom

MULTISPECTRAL MAPAS DIGITAIS (EMPRESA) - Viário principal de ruas de Embu-Guaçu, São Paulo, 20051 mapa. Escala 1:5000. 1 CD Rom

MULTISPECTRAL MAPAS DIGITAIS (EMPRESA) - Viário principal de ruas de Itapecerica da Serra, São Paulo, 20051 mapa. Escala 1:5000. 1 CD Rom

COGNATIS GEOMARKETING (EMPRESA) - Pólos de atração da cidade de São Paulo, São Paulo, 2005. 1 mapa. Escala indeterminável. 1 CD Rom

SEHAB/SP, CNEC, Base SA (EMPRESA). Fotografias aéreas de São Paulo. São Paulo, março 1994 escala 1:50000, fx1 8-9, fx2 7-10, fx3 3-5 e 31-36, fx4 22-27 e 30-38, fx5 19-36, fx6 18-34, fx7A 25-33, fx7 15-24, fx8 14-34, fx9 17-28, fx10 - 1825 resolução 300 dpi formato do arquivo .tif. 14 zips

AFA (Arquivo de fotografias aéreas) FFLCH USP. Fotografias aéreas de São Paulo. São Paulo, 1962. Escala indeterminavel; fx 38 a 42. Arquivo em papel.

AFA (Arquivo de fotografias aéreas) FFLCH USP . Fotografias aéreas de São Paulo. São Paulo, 1974.Escala indeterminavel; Arquivo em papel. 